\title{
The Application of U.S. Upper Wind Data in One Design of Tethered Wind Energy Systems
}

R.J. O'Doherty
B. W. Roberts

February 1982

Prepared under Task No. 1067.10

WPA No. 172-81

Solar Energy Research Institute

A Division of Midwest Research Institute

1617 Cole Boulevard

Golden, Colorado 80401

Prepared for the

U.S. Department of Energy

Contract No. EG-77-C-01-4042 
Printed in the United States of America Available from:

National Technical Information Service

U.S. Department of Commerce

5285 Port Royal Road

Springfield, VA 22161

Price:

Microfiche $\$ 3.00$

Printed Copy $\$ 7.25$

\section{NOTICE}

This report was prepared as an account of work sponsored by the United States Government. Neither the United States nor the United States Department of Energy, nor any of their employees, nor any of their contractors, subcontractors, or their employees, makes any warranty, express or implied, or assumes any legal liability or responsibility for the accuracy, completeness or usefulness of any information, apparatus, product or process disclosed, or represents that its use would not infringe privately owned rights. 


\section{FOREYORD}

The work sumnarized in this report was supported through the Advanced and Innovative Wind Energy Concepts task at the Solar Energy Research Institute (SERI) within the Federal Wind Energy Program of the Department of Energy (DOE). Richard L. Mitchell was the technical project manager.

This report was prepared to support SERI subcontractors working in the field of Tethered Wind Energy Concepts. Data from the National Center for Atmospheric Research in Boulder, Colo. were reduced and analyzed by Robert J. O'Doherty (SERI) and Bryan $W$. Roberts (Visiting Professor from the University of Sydney, Sydney, Australia). Specific sites are described in detail. Additional sites were also analyzed, and results are available from SERI upon request.

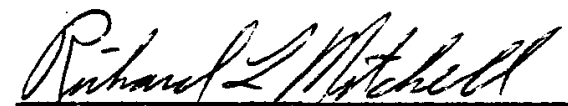

Richard L. Mitchell

SERI Project Manager

Approved for

SOLAR ENERGY RESEARCH INSTITUTE

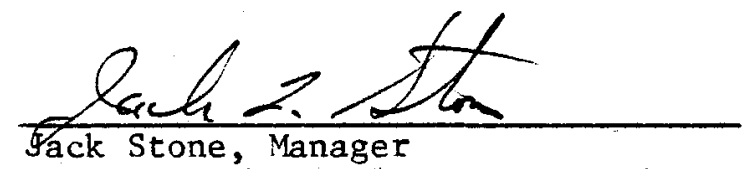

Program Office

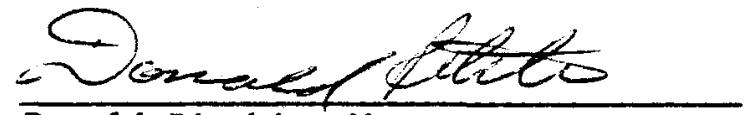

Donald Ritchie, Manager

Solar Electric Conversion Research

Division 


\section{SUMMARY}

\section{Objective:}

This report assesses the upper atmospheric wind resource for the continental United States, Hawaii, and Alaska.

\section{Discussion:}

The document is intended for Solar Energy Research Institute contractors interested in tethered wind energy systems. The raw data were obtained from the National Center for Atmospheric Research, Boulder, Colo.

\section{Conclusion:}

The probability distributions of velocity are presented for 54 sites, and detailed calm wind analyses have been undertaken for five of these locations. On the average, the wind lulls about one day per week for a period in excess of about 30 hours.

The report shows that the average power density of this wind resource can be as high as $16 \mathrm{~kW} / \mathrm{m}^{2}$ at northeastern U.S. sites. This power density is at a maximum around the $300-\mathrm{mb}$ pressure leve1. 


\section{TABLE OF CONTENTS}

Page

1.0 Introduction..................................... 1

2.0 Background of the Concept............................ 3

2.1 Theoretical Foundations........................... 3

2.2 Numerical Techniques............................. 4

2.2 .1 Average wind speed.......................... 5

2.2 .2 Average Power Density.......................... 5

2.2.3 Cumulative Velocity Distribution................ 5

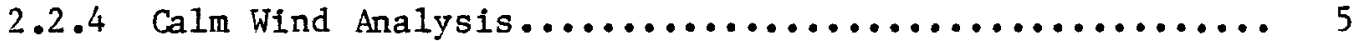

2.2 .5 Procedures for Missing Data................... 6

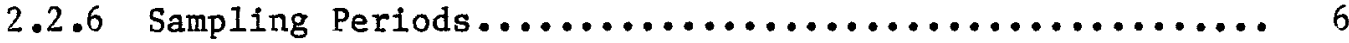

2.2.7 Annual and Monthly Average Values of Velocity and Power Density......................... 6

2.3 Detailed Probability Analysis of the U.S. Upper Winds........ 13

2.4 Power-Duration Curves.............................. 15

2.5 The Annual Calm Period Analysis........................ 16

2.6 The Monthly Calm Period Analysis......................... 19

2.7 Lightning Conditions.............................. 20

2.8 Conclusions.................................... 21

3.0 References....................................... 23

Appendix A - Average Values of Velocity and Power................ 25

Appendix B - Application of U.S. Upper Wind Data in Pre-Design Tethered Wind Energy Systems................... 55

Appendix C - Annual Calm-Period Charts.........................11

Appendix D - Use of the Annual Probability Distribution of Velocity Charts............................. 123 


\section{LIST OF FIGURES}

Page

2-1 Time-Series Wind Data at a Pressure Altitude of p............. 4

2-2 Isopleths of Mean Power Density $\left(\mathrm{kW} / \mathrm{m}^{2}\right)$ at $300 \mathrm{mb} \ldots \ldots \ldots \ldots \ldots$

2-3 Isopleths of Mean Power Density $\left(\mathrm{kw} / \mathrm{m}^{2}\right)$ at $400 \mathrm{mb} \ldots \ldots \ldots \ldots$

2-4 Isopleths of Mean Power Density $\left(\mathrm{kW} / \mathrm{m}^{2}\right)$ at $500 \mathrm{mb} \ldots \ldots \ldots \ldots \ldots 11$

2-5 Isopleths of Mean Power Density $\left(\mathrm{kw} / \mathrm{m}^{2}\right)$ at $700 \mathrm{mb} \ldots \ldots \ldots \ldots \ldots 12$

2-6 Monthly Average Power Density: Portland, ME................. 13

2-7 Annual Probability Distribution of Velocity: Portland, ME........ 14

2-8 Annual Power-Duration Curve: Portland, ME................ 15

2-9 Annual Calm-Period Analysis: Portland, ME................. 17

2-10 Annual Calm-Period Analysis: Portland, ME................ 18

2-11 Number of Occasions per Month Wind Speed is Below $15 \mathrm{~m} / \mathrm{s}$ :

Portland, ME..................................... 19

2-12 Average Period Wind Speed is Below $15 \mathrm{~m} / \mathrm{s}$ : Portland, ME........ 20

2-13 Annual Average Number of Thunderstorm Days................. 21

LIST OF TABLES

Page

2-1 Annual Average Values of Velocity and Power: Portland, ME........ 7

2-2 U.S. Sites Considered for Annual Average Values of Velocity

and Power.......................................... 8 


\section{SE CTION 1.0}

\section{INTRODUCTION}

The Solar Energy Research Institute (SERI) has recently awarded study contracts to assess and to recommend ways to harness the energy in the earth's upper atmospheric wind system.

Jet streams flow continually in mid-latitudes in both hemispheres due to the effect of both solar radiation on the tropics and cooling in the arctic regions with the rotation of the earth on its axis. Reiter, in his classic text on meteorology of the jet streams [1], describes the subtropical and polar-front jet stream systems. Both these jets flow over the United States, but their confluence and meandering patterns lead to a variability in the strength and persistence of the winds at any one fixed site. The variability in the strength and location of these jets is the subject of this report.

Note that an assessment of the winds aloft is integral to the decision about the siting, viability, and practicality of the various types of tethered wind energy systems.

This report is restricted to a statistical assessment of the U.S. upper wind resource. It has been compiled from "Time Series Upper Wind Data," supplied to SERI by the National Center for Atmospheric Research (NCAR), located in Boulder, Colo. These wind data are available for a variety of sites throughout the world, but this study is limited to the continental United States, Hawaii, and Alaska. 


\section{SEP1}


SECTION 2.0

\section{BACKGROUND OF THE CONCEPT}

The current statistical survey uses wind energy conversion platforms, if they can be located at sites remote fron the earth's surface.

We will show that the availability of this wind energy resource increases with altitude up to around $200 \mathrm{mb}$. In addition, at favorable U.S. sites, the power density can be as high as $17 \mathrm{~kW} / \mathrm{m}^{2}$, while at sites in the southern hemisphere the power density can be around $19 \mathrm{~kW} / \mathrm{m}^{2}$ [2].

Note that the conversion of mechanical energy from winds invariably produces aerodynamic drag forces. In addition, the conversion of kinetic energy will generate a drag force that will be collinear with the free-stream velocity vector. This drag force must be balanced if a useful energy conversion is to be produced.

These drag loads may be resisted by a tethering cable or cables. One end of the cable would be attached to the platform, and the other end would be fixed to the earth's surface. Subsystems other than a tethering cable might be used to balance the drag load.

Finally, the means by which the converted energy will be transmitted to the earth's surface are left undefined. One can, however, assert that the average power density in the upper atmosphere is highly concentrated when compared to other renewable resources, such as direct solar radiation or wind energy near the surface.

\subsection{THEORETI CAL FOUNDATIONS}

By using standard wind energy techniques, we want to represent the cumulative probability distribution of the wind speed $\mathrm{V}$ by an integrated Weibull model:

$$
\begin{aligned}
& P(V)=1-e^{-\left(V / V_{0}\right)^{\alpha}} \text { for } V \geqslant 0 \\
& P(V)=0 \text { elsewhere, }
\end{aligned}
$$

where $V_{0}$ and $\alpha$ are two constants that give a good fit to the data.

The use of the Weibull distribution is common [3-6] in wind energy applications. Furthermore, the Rayleigh model is a special case of the Weibull model where $\alpha=2$. The application of these Rayleigh/Weibull models has become an established wind energy practice for the analysis of near-surface winds and is also satisfactory for modeling upper wind data.

However, conventional meteorological techniques represent upper wind data with a bivariant normal distribution $[7,8]$ so that the wind components in the zonal $(\mathrm{E}-\mathrm{W})$ and meridional (N-S) directions can be represented by suitable averages and standard deviations. This model allows meteorologists to introduce wind constancy, vector means, and various wind components. However, in this report 
it is more appropriate to fit a Weibull distribution to the scalar wind distribution.

These raw rawinsonde data have been used to define the distributions. The standard pressure altitudes of $950,850,750,700,600,500,400,300,250$, and $200 \mathrm{mb}$ are used to define the various vertical sectors.

In summary, the probability distributions of velocity will be compiled for a series of altitudes at 54 sites selected across the United States and its territories. Then probability distributions can be plotted on a log-log scale. (This graph paper will be referred to as Weibull paper.) Further details of this type of representation can be found in a report by Takle and Brown [3]. On this class of graph paper, the Weibull distribution plots a straight line with a slope of $\alpha / 2$, which passes through point $V=V_{0}, P(V)=1-1 / e$. This treatment (see Fig. 2-7) allows one to easily evaluate $\alpha$ by use of the side nomogram. The magnitude of $\mathrm{V}_{0}$ is given by the intersection of appropriate distribution with the $63.2 \%$ ordinate (shown as a dotted line in the Eigures). More details on the use of these charts are given in Appendix $D$.

\subsection{NUMERI CAL TECHNIQUES}

These raw rawinsonde data were obtained from NCAR. These tapes contained, among other information, a series of one-half day samples of wind velocity and air temperature at the standard pressure altitudes. These data were collected from balloon soundings launched at 0000 and 1200 hours GMT from fixed sites.

The numerical analysis can best be described by reference to Fig. 2-1, which is a segment of the time-series wind data at a pressure altitude $p$. The data extend from day $n$ to day $(n+4)$.

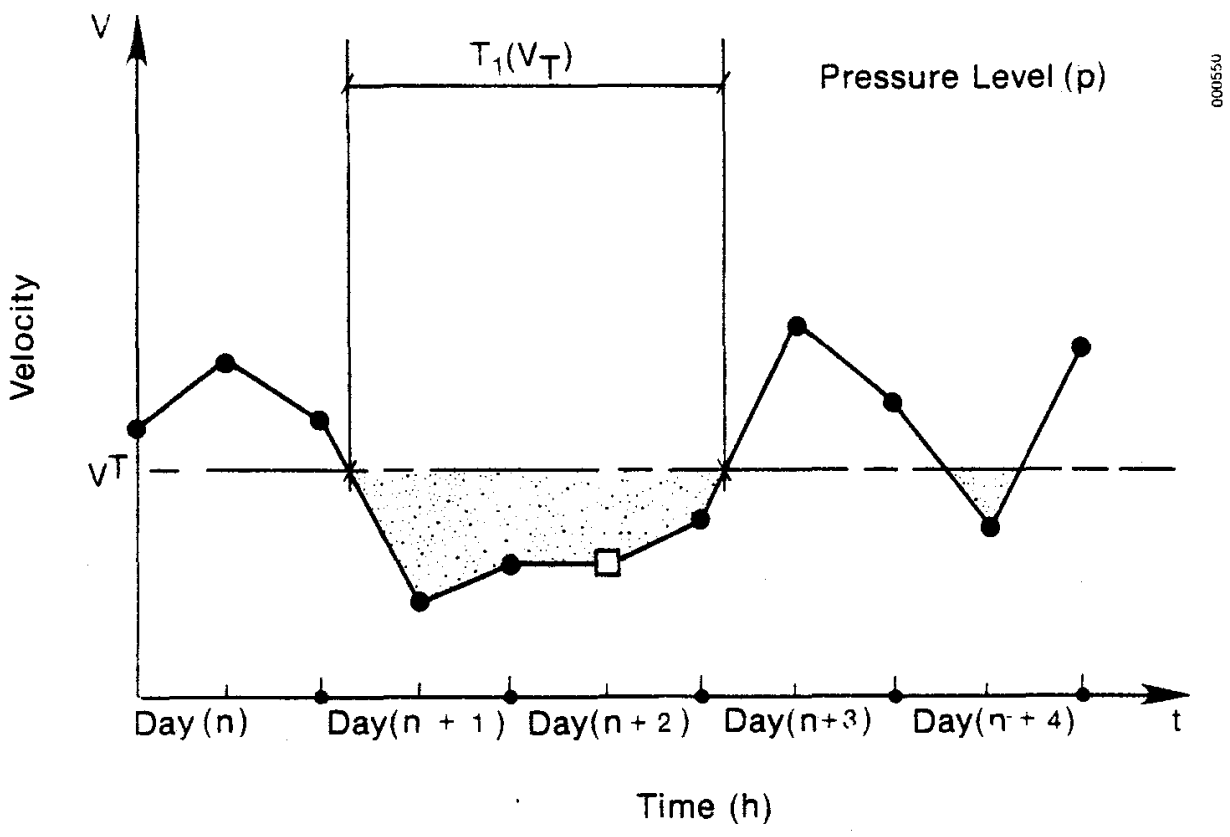

Figure 2-1. Time-Series Wind Data at a Pressure Altitude of $\mathbf{p}$ 


\subsubsection{Average Wind Speed}

The average wind speed is the sumation of the observations divided by the total number of observations:

$$
\bar{V}=\sum_{c=i}^{N} V_{i} / N
$$

\subsubsection{Average Power Density}

The average power density is defined as

$$
\bar{P}=1 / 2 \sum_{i=1}^{N} \rho_{i} v_{i} 3 / N \text {. }
$$

The air density $\rho_{i}$ has been derived from the equation of state as

$$
\rho_{i} \simeq 0.35 \mathrm{P} /\left(\mathrm{T}_{i}+273\right),
$$

where $T_{i}$ is the $i$ th observation of the air temperature.

\subsubsection{Cumulative Velocity Distribution}

The cumulative velocity distribution at the velocity $\mathrm{V}$ is physically the percentage probability for which the wind velocity will be less than or equal to the value of $V$ :

$$
P(V)=100 n(V) / N,
$$

where $n(V)$ is the number of observations when the velocity is less than or equal to $\mathrm{V}$. The total number of observations $N$ is approximately 5100 per site in this study.

\subsubsection{Calm Wind Analysis}

A calm wind survey is important in the design and operation of any tethered system.* Although it is important to know the cumulative probability $P\left(V_{T}\right)$, it is equally significant to know how long, on the average, the wind is below the threshold velocity $V_{T}$. Also we would like to know on how many occasions in a given period the winds will fall below the threshold value. In mathematical form, this implies that:

$$
P\left(V_{T}\right) \simeq \bar{T}\left(V_{T}\right) N\left(V_{T}\right) 100 / 8760,
$$

*The importance of the calm wind analysis will be discussed at length in Secs. 8.0 and 9.0 . 
where

$P\left(V_{T}\right)$ is the probability the velocity will be equal to or below a speed of $V_{T}$;

$V\left(V_{T}\right)$ is the average number of times per year that the wind falls below the threshold speed; and

$\bar{T}\left(V_{T}\right)$ is the average period in hours that the wind speed is below thrèshold.

If $\mathrm{N}\left(\mathrm{V}_{\mathrm{T}}\right)$ were compiled monthly, then the denominator in $\mathrm{Eq} \cdot 6$ will be 730 .

In Fig. 2-1, for example, the first downtime is $T_{1}\left(V_{T}\right)$ hours. Therefore, a value of unity is accumulated into the count of $N\left(V_{T}\right)$, while a value of $T_{1}\left(V_{T}\right)$ is counted into the running average of $\bar{T}\left(V_{T}\right)$. A linear interpolation scheme has been used to compute the downtimes. Furthermore, the standard deviation of $T\left(V_{T}\right)$ has been computed and will be discussed later.

\subsubsection{Procedures for Missing Data}

of approximately five thousand samples at each site and altitude, we found that about $1 \%$ to $2 \%$ of data were missing for two reasons.

First, occasionally, the rawinsonde sounding was completely missing due to radar breakdown or poor weather conditions. In this case, the data were effectively moved to the left, on Fig. 2-1, by one day. Thus, no gaps were introduced into the string of soundings. On other rare occasions, three or four soundings were taken in one day. Under these circumstances, the information in Fig. 2-1 was moved to the right to receive the extra data.

Secondly, on some occasions, the rawinsonde flight was abandoned too early, perhaps because of a premature bursting of the balloon. In this case, we assumed the missing data (shown as the open square symbol in Fig. 2-1) were of the same value as those from the previous sounding at the same altitude.

We believe this treatment of the missing data is reasonable. However, other techniques are possible, but the technique used should not significantly affect the result.

\subsubsection{Sampling Periods}

We have evaluated parameters in Secs. 2.2.1 to 2.2.5 for each month in a seven-year period. We have also assembled annual statistics for the 54 sites in the United States.

\subsubsection{Annual and Month1y Average Values of Velocity and Power Density}

The average velocity and power density can be determined from the raw data by the use of Eqs. 2 to 4 . Average values of both of these vartables are given 
in Table 2-1. This figure uses Portland, Maine, as an example, and nine altitudes are listed.

Table 2-1. Annual Average Values of Velocity and Power: Portland, ME

\begin{tabular}{ccc}
\hline $\begin{array}{c}\text { Altitude } \\
(\mathrm{mb})\end{array}$ & $\begin{array}{c}\text { Velocity } \\
(\overline{\mathrm{V}}, \mathrm{m} / \mathrm{s})\end{array}$ & $\left(\overline{\mathrm{P}}, \mathrm{pW} / \mathrm{m}^{2}\right)$ \\
\hline 900 & 9.42 & 1.11 \\
850 & 10.4 & 1.36 \\
700 & 14.8 & 2.84 \\
600 & 18.4 & 4.67 \\
500 & 22.5 & 7.53 \\
400 & 27.6 & 11.4 \\
300 & 32.8 & 14.1 \\
250 & 33.9 & 12.9 \\
200 & 31.2 & 7.90 \\
\hline
\end{tabular}

The same calculations have been performed for 53 other U.S. sites. The relevant values are given in Appendix $A$ as Tables $A-1$ through $A-54$. The appendix considers the sites alphabetically (see Table 2-2).

From the annual average power-density figures given in Appendix A, one can draw resource maps showing the isopleths of power density at the various altitudes. Figures $2-2$ to $2-5$ show these charts for the $300,400,500$, and $700 \mathrm{mb}$ levels, respectively.

In the United States, the wind energy resource is primarily concentrated in the Northeast, where the average power density can be in excess of $16 \mathrm{~kW} / \mathrm{m}^{2}$. At $300 \mathrm{mb}$, the power density falls to about $8 \mathrm{~kW} / \mathrm{m}^{2}$ in the Midwest, and it falls further to about $4 \mathrm{~kW} / \mathrm{m}^{2}$ in equatorial regions.

Note that the jet stream is the dominant influence in the upper air resource. The power density essentially reflects the average residence time that a jet spends above a site as the jet "meanders" over the continent.

Finally, monthly values of power density can be calculated from the raw data. This can be completed for all stations if required, but typical results can be seen in the output for Portland, Maine. Figure 2-6 shows the monthly average power densities for Portland; the results were derived from a sevenyear sample.

Figure 2-6 shows that the power density is at a maximum of about $30 \mathrm{~kW} / \mathrm{m}^{2}$ in January and falls to $7 \mathrm{~kW} / \mathrm{m}^{2}$ in $\mathrm{July}$. The maximum and minimum values occur about one month after the winter and summer solstices, respectively [1]. 
Table 2-2. U.S. Sites Considered for Annual Average Values of Velocity and Power

\begin{tabular}{ll}
\hline Albany, NY & Montgomery, AL \\
Albuquerque, NM & Nashville, TN \\
Bismarck, ND & New York, NY \\
Boise, ID & North Platte, NE \\
Brownsville, TX & Oakland, CA \\
Buffalo, NY & Oklahoma City, OK \\
Caribou, ME & Omaha, NE \\
Charleston, SC & Peoria, IL \\
Dayton, OH & Pittsburgh, PA \\
Del Rio, TX & Portland, ME \\
Denver, CO & Rapid City, SD \\
Dodge City, KS & St. Cloud, MN \\
Ely, NV & Salem, IL \\
Fairbanks, AK & Salem, OR \\
Fort Worth, TX & Salt Lake City, UT \\
Glasgow, MT & San Nichols Island, CA \\
Great Falls, MT & Sault Ste. Marie, MI \\
Green Bay, WI & Shreveport, LA \\
Greensboro, NC & Spokane, WA \\
Guadalupe Island, Mexico & Tampa, FL \\
Hilo, HI & Topeka, KS \\
Huntington, WV & Tucson, AZ \\
International Falls, MN & Wallops Island, VA \\
Lander, WY & Waycross, GA \\
Little Rock, AR & Winnemucca, NV \\
Medford, OR & Winslow, AZ \\
Midland, TX & Yucca Flats, NV \\
\hline
\end{tabular}




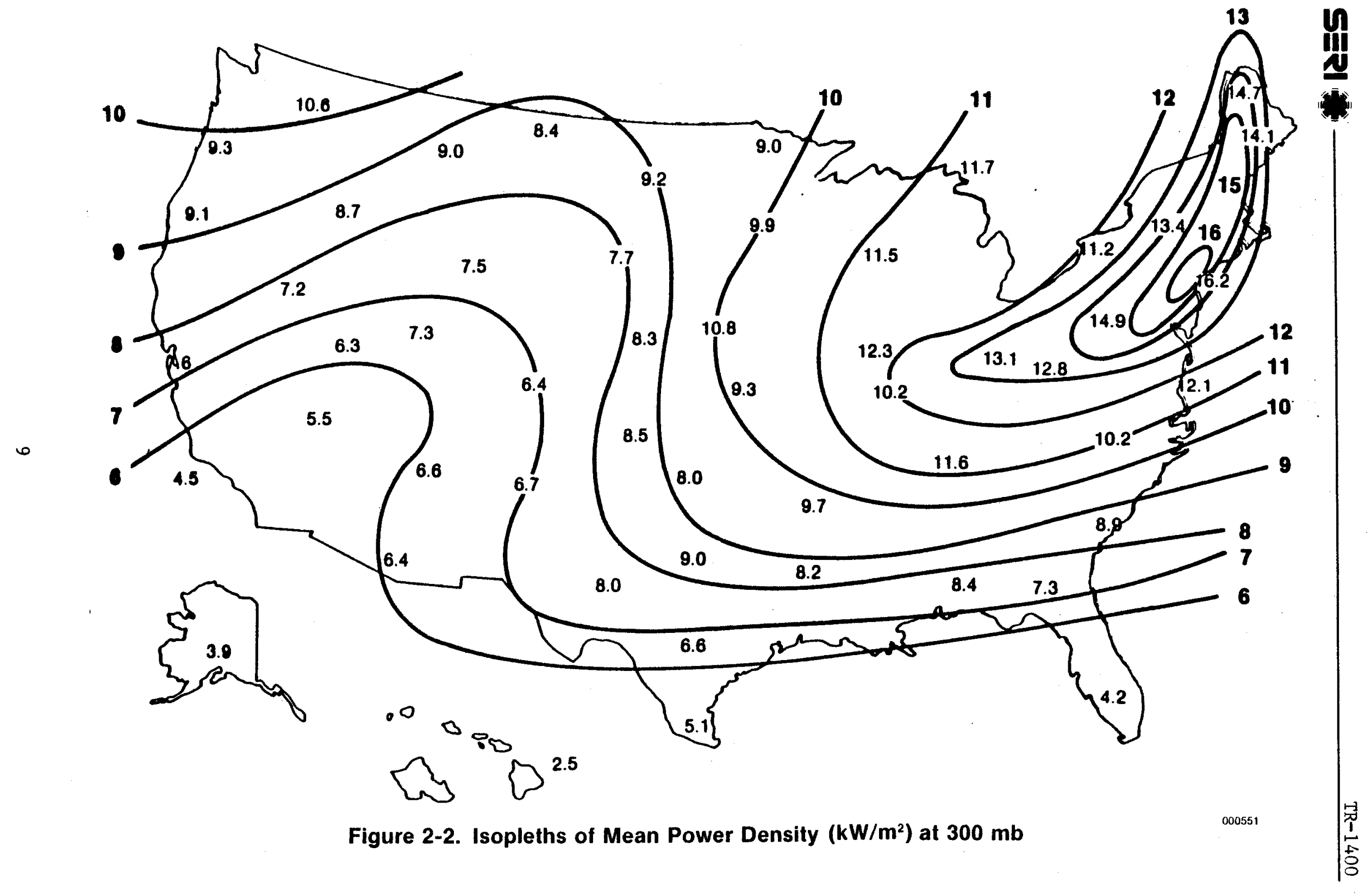




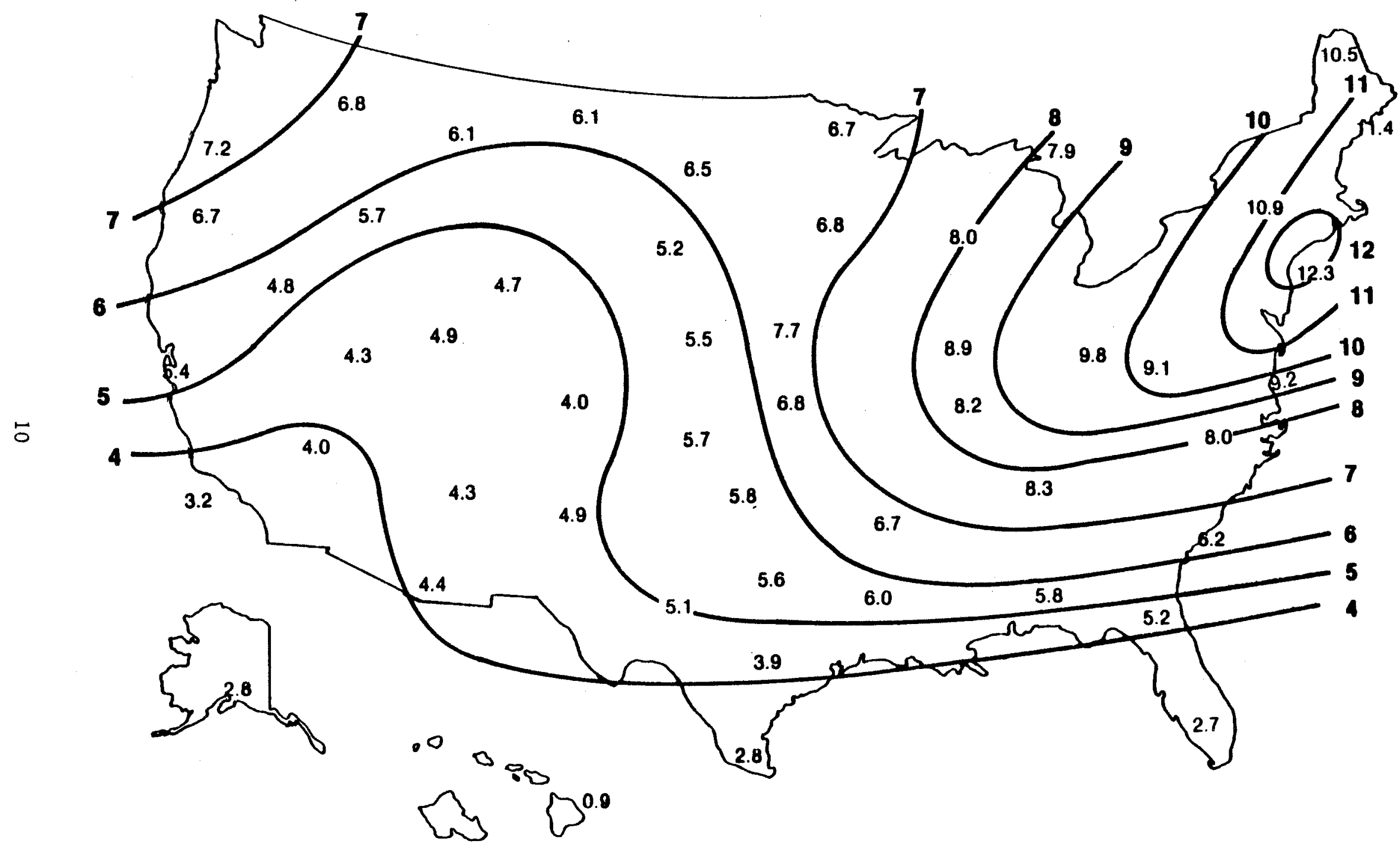

Figure 2-3. Isopleths of Mean Power Density $\left(\mathrm{kW} / \mathrm{m}^{2}\right)$ at $400 \mathrm{mb}$

000552 


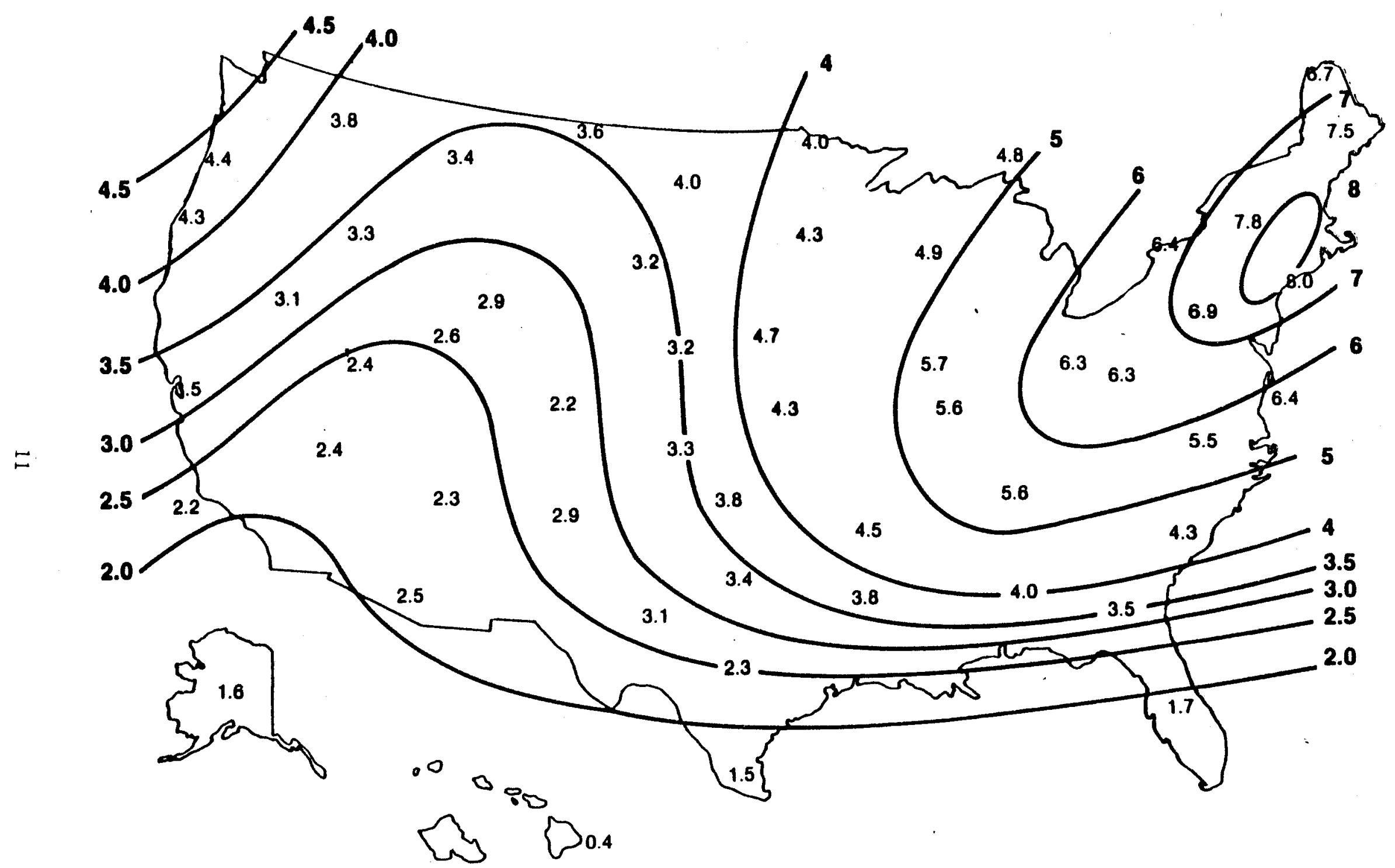

Figure 2-4. Isopleths of Mean Power Density $\left(\mathrm{kW} / \mathrm{m}^{2}\right)$ at $500 \mathrm{mb}$ 


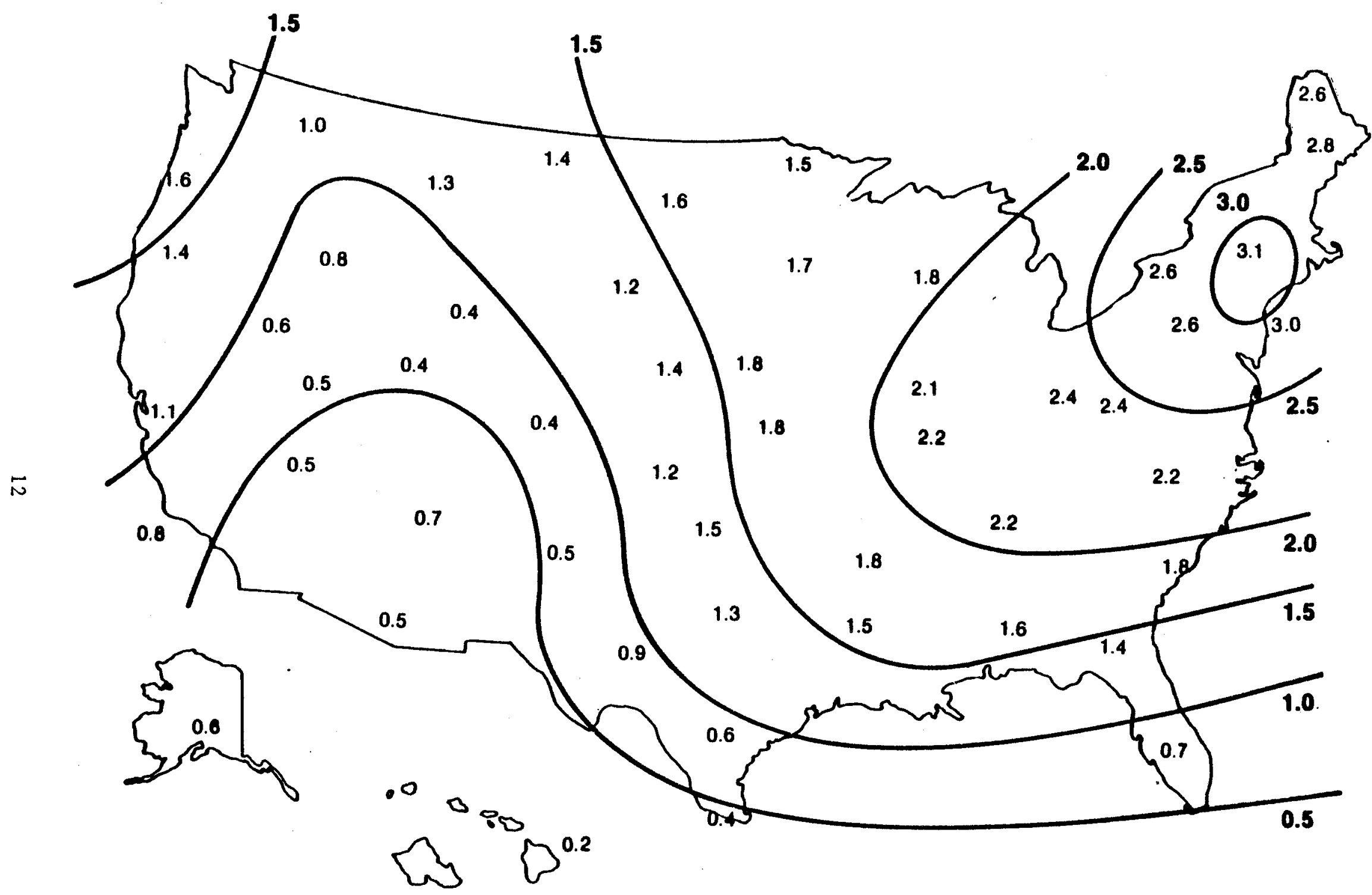

Figure 2-5. Isopleths of Mean Power Density $\left(\mathrm{kW} / \mathrm{m}^{2}\right)$ at $700 \mathrm{mb}$ 


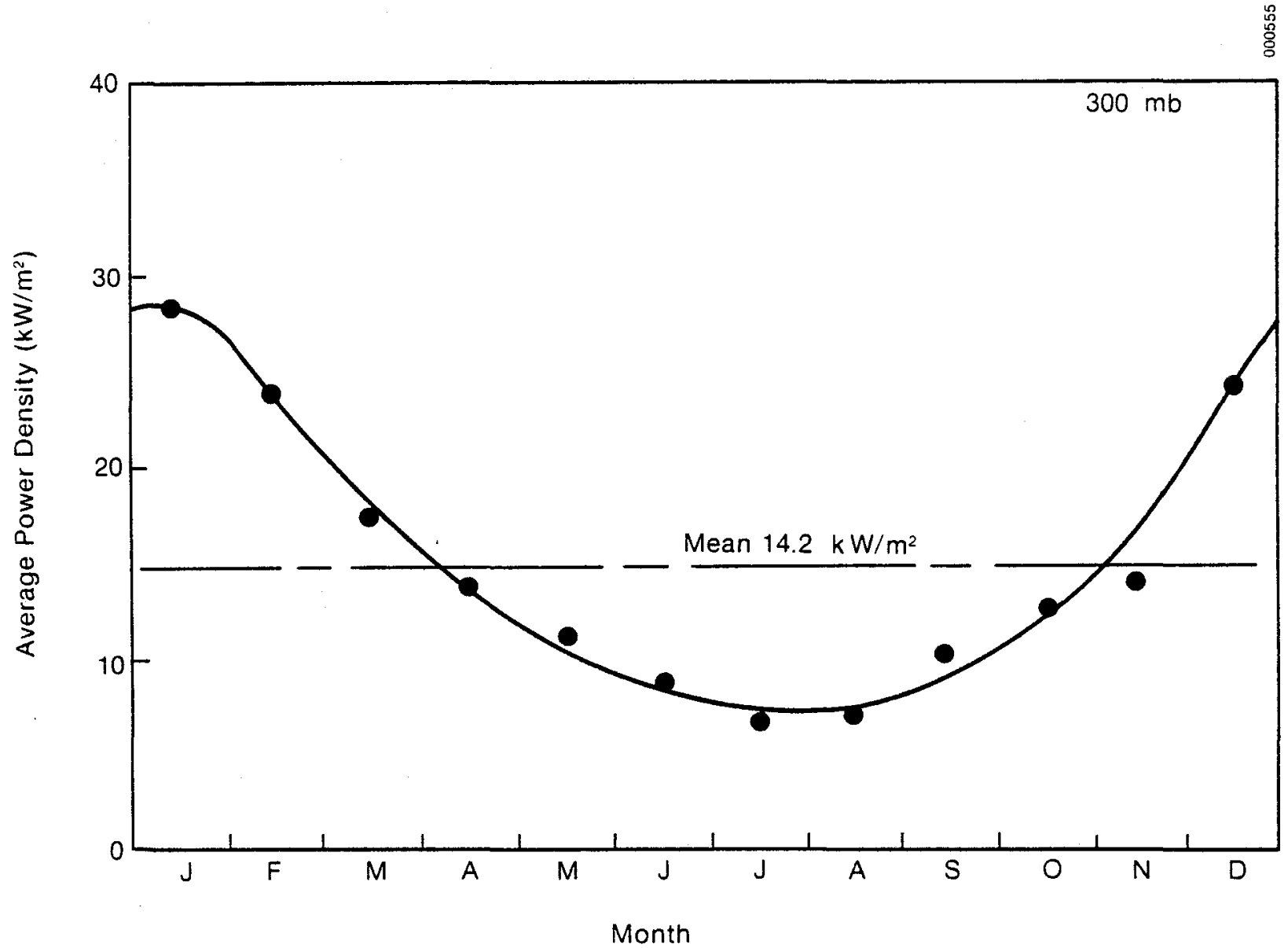

Figure 2-6. Monthly Average Power Density: Portland, ME

\subsection{DETAILED PROBABILITY ANALYSIS OF THE U.S. UPPER WINDS}

A typical, cumulative probability distribution of velocity is shown in Fig. 2-7 for Portland, Maine. Here distributions for the pressure levels of $700,500,400,300$, and $200 \mathrm{mb}$ are approximated by straight-line Weibull distributions. In all cases, the actual distributions are closely modeled by the Weibull distributions. The intersection of the approximating straight line with the dotted line gives the value of $V_{0}$ in $\mathrm{Eq} .1$. The slope of the straight line gives the value of the exponent $\alpha$ which is also in Eq. 1. More details of the distributions for the 54 sites are given in Appendix $B$ as Figs. B-1 through B-54. These figures are relevant to the design of tethered wind energy conversion systems. For example, it is conventional to use figures similar to Figs. B-1 to $B-54$ in the design of a typical windmill. From the probability distribution of velocity, it is simple to derive the 


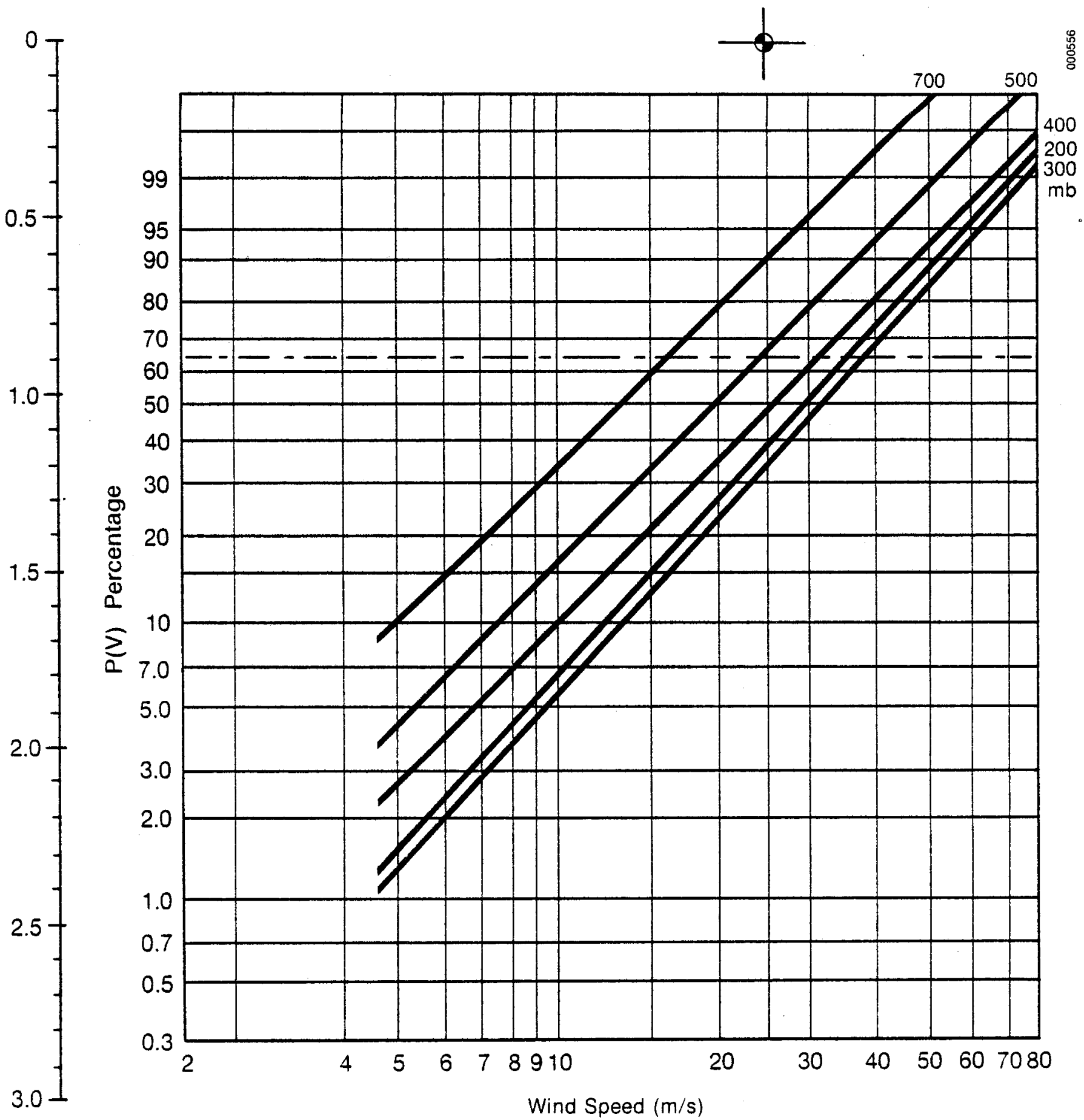

Figure 2-7. Annual Probability Distribution of Velocity: Portland, ME 
power-duration curve for that location. These charts may then be used to complete the well-known cost-of-energy calculation. Presumably, an optimal arrangement would minimize this energy cost. An important aspect of this optimization procedure is the manipulation of the probability distribution functions given earlier.

\subsection{POWER-DURATION CURVES}

The power-duration curve for any of the listed sites, at the relevant altitude, may be determined from the appropriate figure in Appendix $B$. It is simple to select a series of velocities, form the product $1 / 2 \mathrm{\rho} \mathrm{V}^{3}$, and plot this function against $B 760 \mathrm{P}(V)$, the effective duration period. The value of $\rho$ can be determined from standard tables or by use of Eq 4 .

A typical annual power-duration calculation is shown in Fig. 2-8 for Portland, Maine, at the altitude of $300 \mathrm{mb}$. One can determine a similar curve for any other site and altitude.

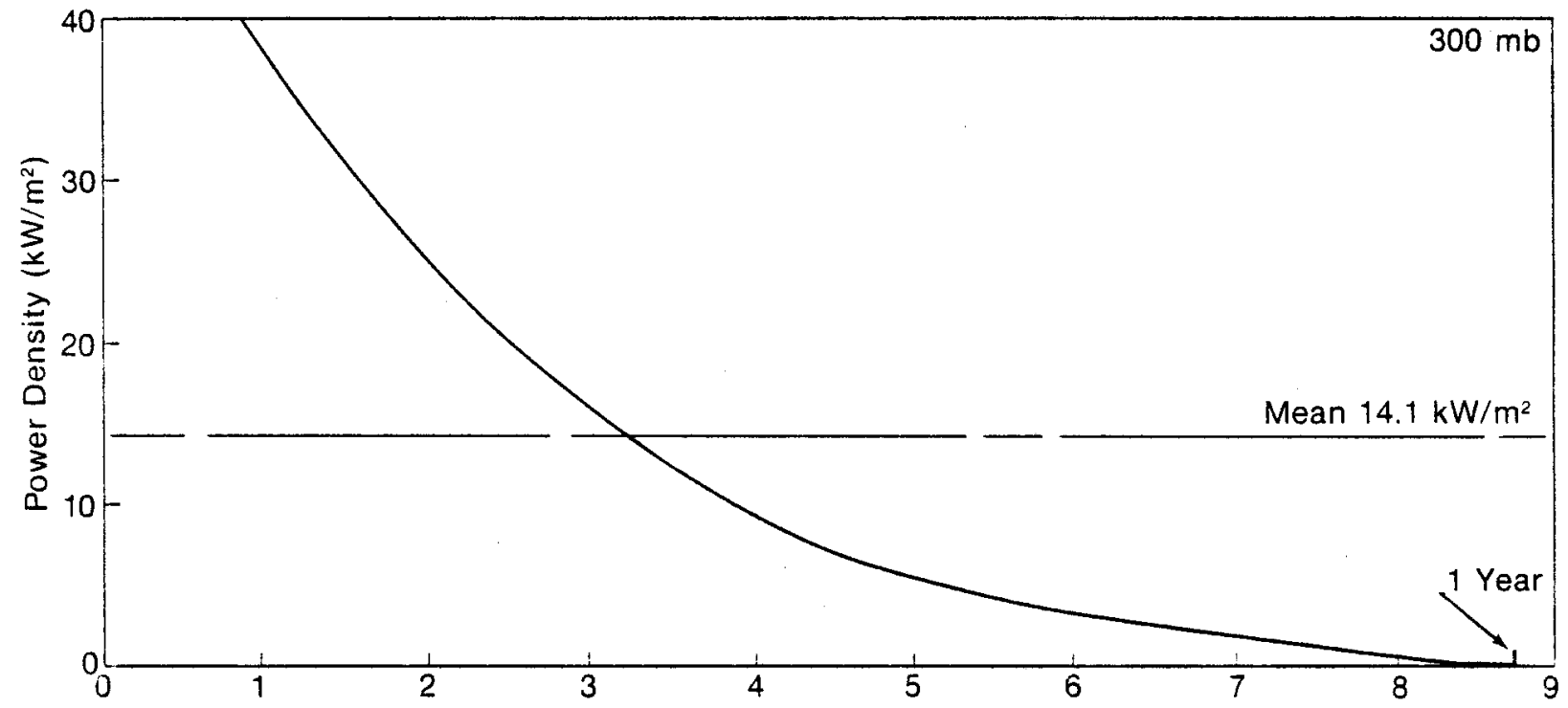

Hours $\times 10^{3}$

Figure 2-8. Annual Power-Duration Curve: Portland, ME 


\subsection{THE ANNUAL CALM PERIOD ANALYSIS}

The economic and pragmatic conversion of wind energy at an altitude that is remote from the earth's surface is critically dependent on calm periods in the tropopause. A velocity (referred to as the threshold velocity) will be used to define the onset of a calm period aloft. This velocity could be equal to the stalling speed of some fixed wind energy conversion platforms. However, it might be the minimum auto-rotative speed of some rotary wing device. Also, it might be the speed at which a balloon is deployed from a hybrid, fixed wing-balloon platform. This minimum, or threshold, speed will be, in principle, the threshold condition that defines a change in the operating modes of a tethered platform. Furthermore, this report is not intended to discuss the merits of an operating mode in any particular system. This report will stress that low-wind periods are an important variable that can be extracted from the time series wind data.

In $\mathrm{Eq} .6$ we defined the parameters $N\left(V_{T}\right)$ and $\bar{T}\left(V_{T}\right)$. The former is the total number of individual occasions in a typical year or month that the wind speed drops below the threshold speed. The companion parameter is $\bar{T}\left(\nabla_{T}\right)$; i.e., the number of hours, on the average, that the wind stays below the threshold velocity. The average can be taken over a month or a year, whichever is desired. Note that the product of $\mathrm{N}$ and $\overline{\mathrm{T}}$, relative to the number of hours in a year or month, is the cumulative probability at the velocity $V_{T}$.

A large value for $N$ and a small value for $\bar{T}$ may be an unfavorable combination for tethered systems. The inverse situation may be more attractive. Then the calms would be as long as possible on relatively few occasions.

The current data have been analyzed to evaluate the functions $N$ and $\bar{T}$ through a range of the parameter $V_{T}$ from 5 to $40 \mathrm{~m} / \mathrm{s}$. The annual average values of $N$ and $\overline{\mathrm{T}}$ are given in Figs. 2-9 and 2-10. These charts refer to Portland, Maine. Further charts for Denver, Colo.; Guadalupe Island, Mexico; Midland, Texas; and Oakland, Calif., are given in Appendix $C$ as Figs. C-1 through $\mathrm{C}-10$. Curves are given for the pressure levels of $600,500,400,300$, and $200 \mathrm{mb}$. Data for additional locations and levels are available on request from SERI.

Figure 2-9 and other charts in Appendix $C$ show that the value of $N$ decreases with increasing altitude for the velocity in the range $0<V_{T}<25 \mathrm{~m} / \mathrm{s}$. Beyond $25 \mathrm{~m} / \mathrm{s}$, the situation is reversed.

In Fig. 2-10 the average time $\bar{T}$ increases steeply with increasing velocity, which occurs at all altitudes. Conversely, as the altitude increases, the time period decreases. One might conclude that at a typical U.S. site the wind lulls approximately below $20 \mathrm{~m} / \mathrm{s}$ weekly. In addition, the annual average time $\overline{\mathrm{T}}$ below $20 \mathrm{~m} / \mathrm{s}$ is always greater than 30 hours, regardless of the altitude or site location. Furthermore, from the statistical analysis, we have observed that the standard deviation in $T\left(V_{T}\right)$ is of the same order as the mean $\bar{T}\left(V_{T}\right)$, indicating the variation one might expect for $T\left(V_{T}\right)$ in any practical situation. 


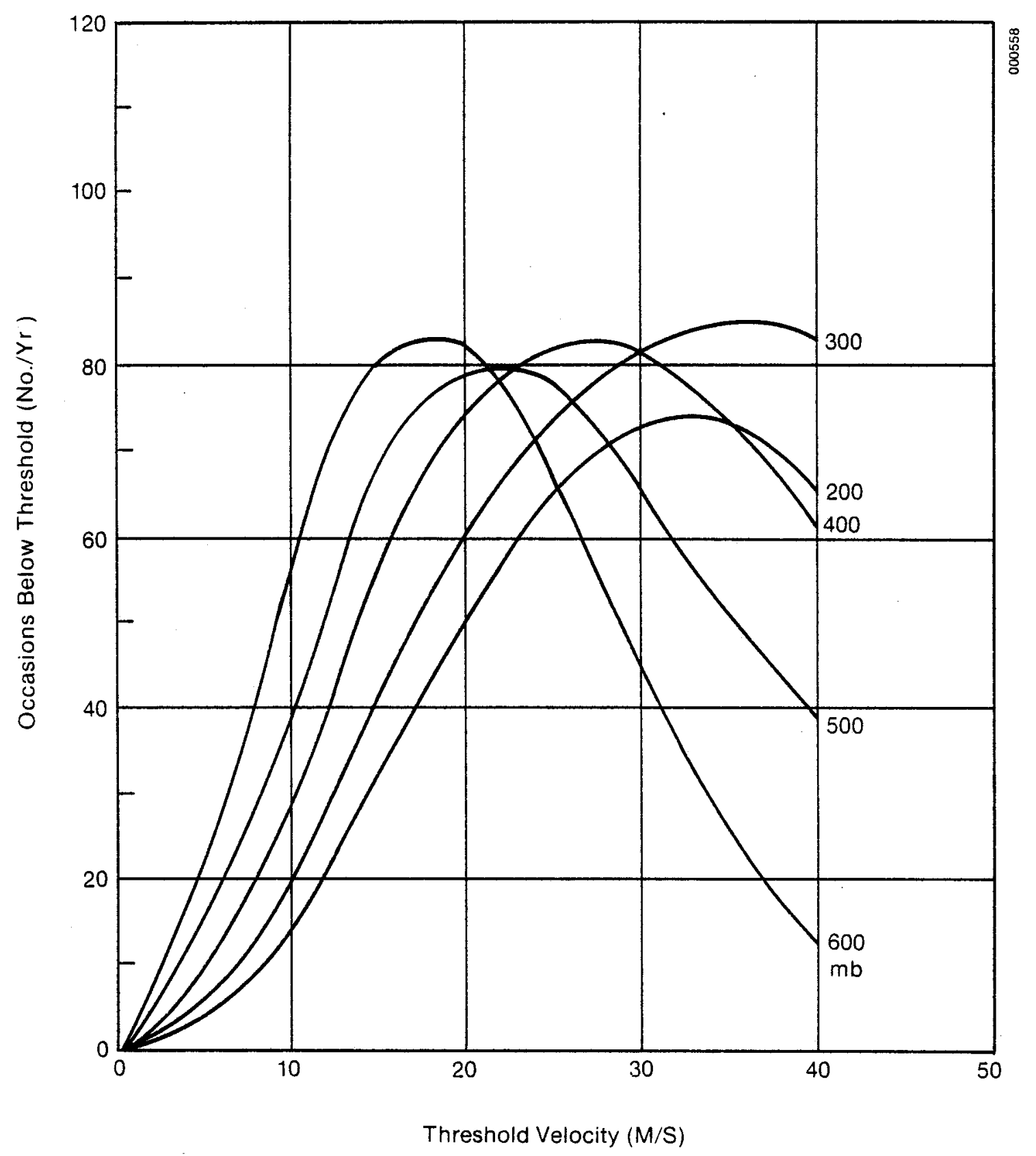

Figure 2-9. Annual Calm-Period Analysis: Portland, ME 


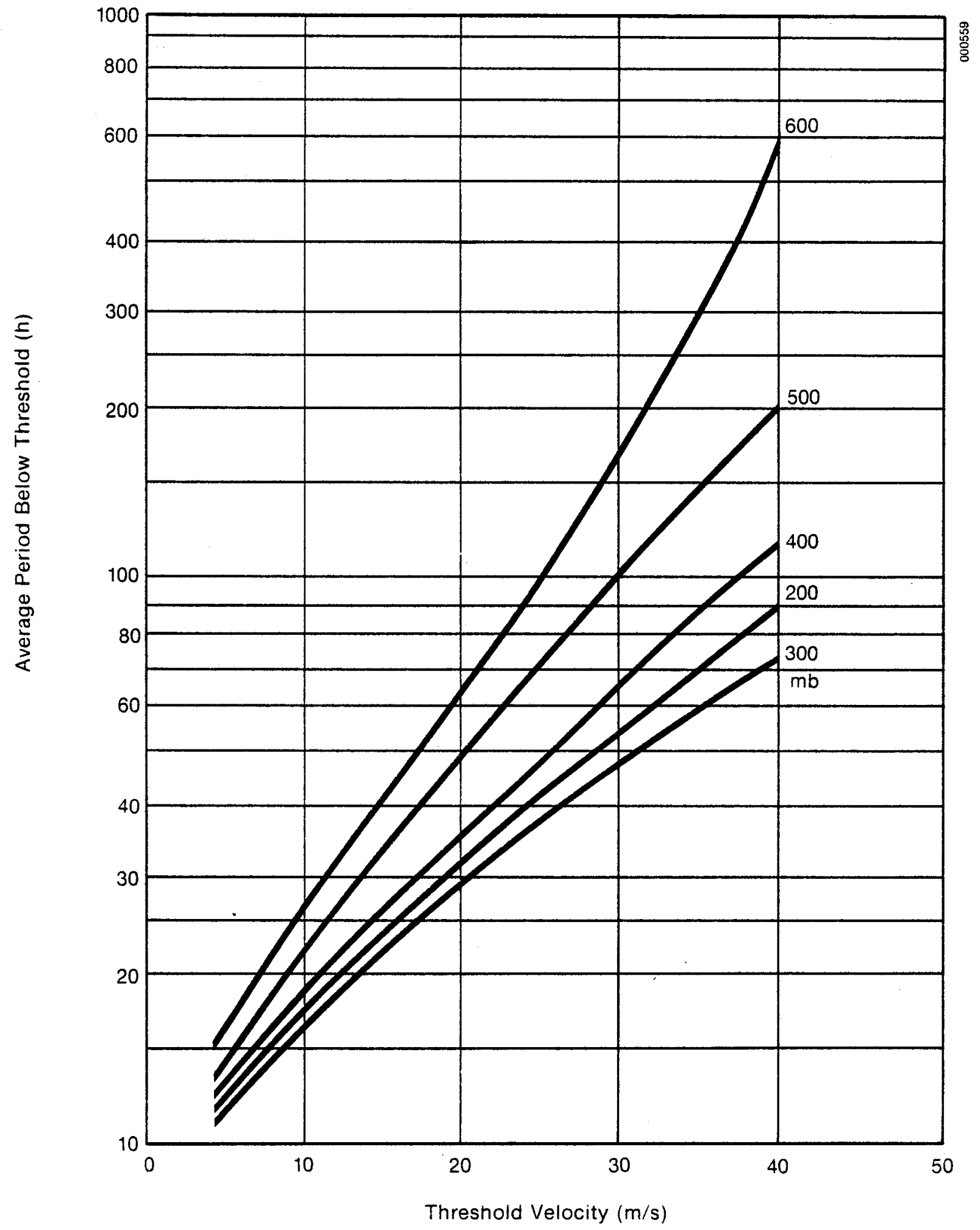

Figure 2-10. Annual Calm-Period Analysis: Portland, ME 


\subsection{THE MONTHLY CALM PERIOD ANALYSIS}

Data for the 54 stations have been analyzed at the monthly level. However, it is impossible to present all data now. Therefore, we suggest that Portland, Maine, might be considered an optimistic U.S. site.

The results of the monthly analysis at $300 \mathrm{mb}$ with $V_{T}=15 \mathrm{~m} / \mathrm{s}$ for Portland are shown in Figs. 2-11 and 2-12. Scrutiny of the figures indicates that July, one month past the summer solstice, has the least wind. In July, for a threshold of $15 \mathrm{~m} / \mathrm{s}$, the winds will calm on about 6 occasions for about 30 hours each. In the windiest month, January, the wind will fall below $15 \mathrm{~m} / \mathrm{s}$ on about 1.3 occasions per month for a period of about 10 hours on each occasion.

In summary, if $15 \mathrm{~m} / \mathrm{s}$ is the stalling speed of a certain aerodynamic platform, then the system will tend to collapse whenever the wind lulls below this speed. In other words, collapse situations will occur according to Fig. 2-11, and the downtime will last for the period indicated in Fig. 2-12.

If the platform's stalling speed is in excess of $15 \mathrm{~m} / \mathrm{s}$, the collapse occasions and periods will generally increase. However, the inverse situation will occur for stalling speeds less than $15 \mathrm{~m} / \mathrm{s}$.

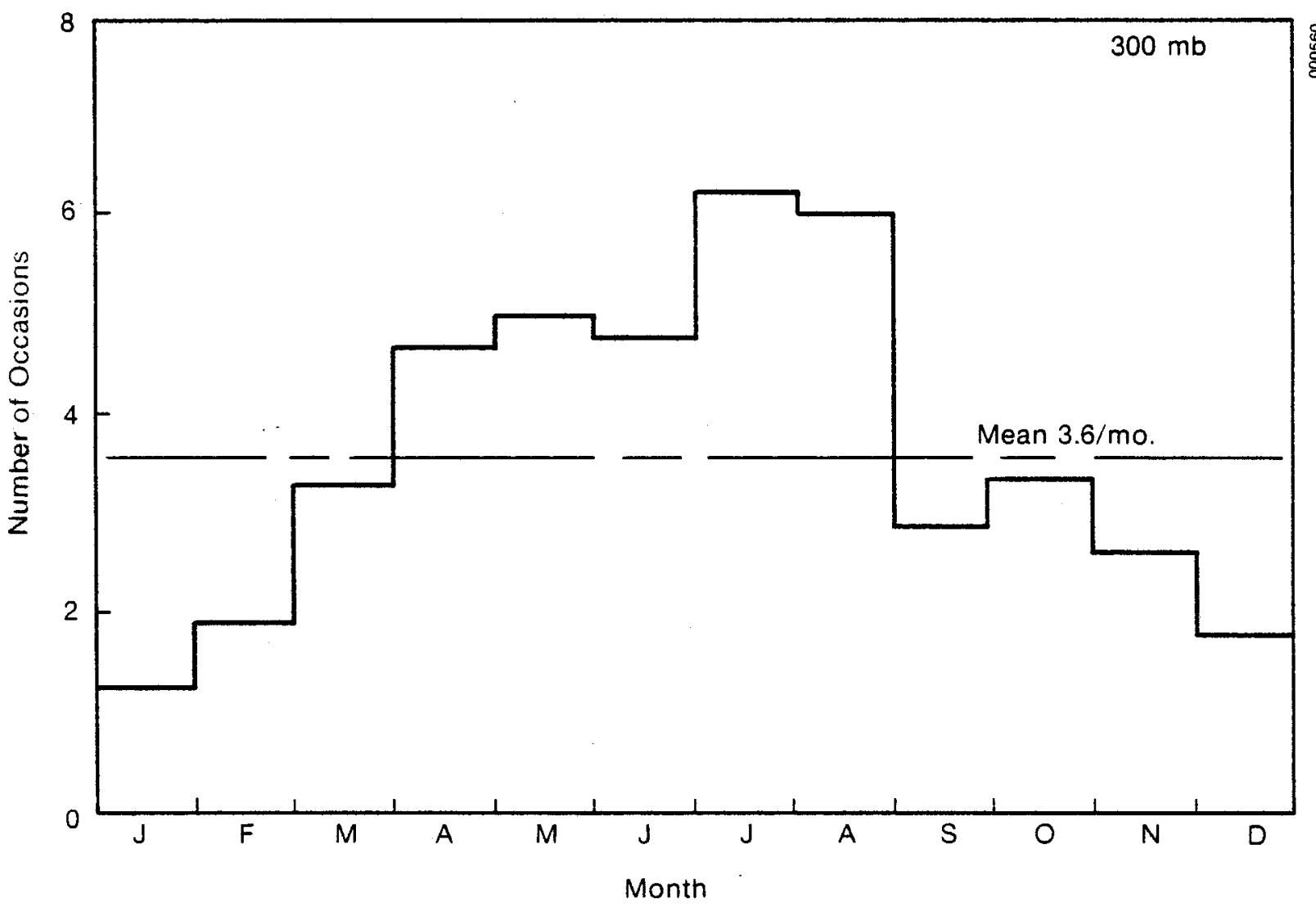

Figure 2-11. Number of Occasions Per Month Wind Speed Falls Below $15 \mathrm{~m} / \mathrm{s}$ : Portland, ME 


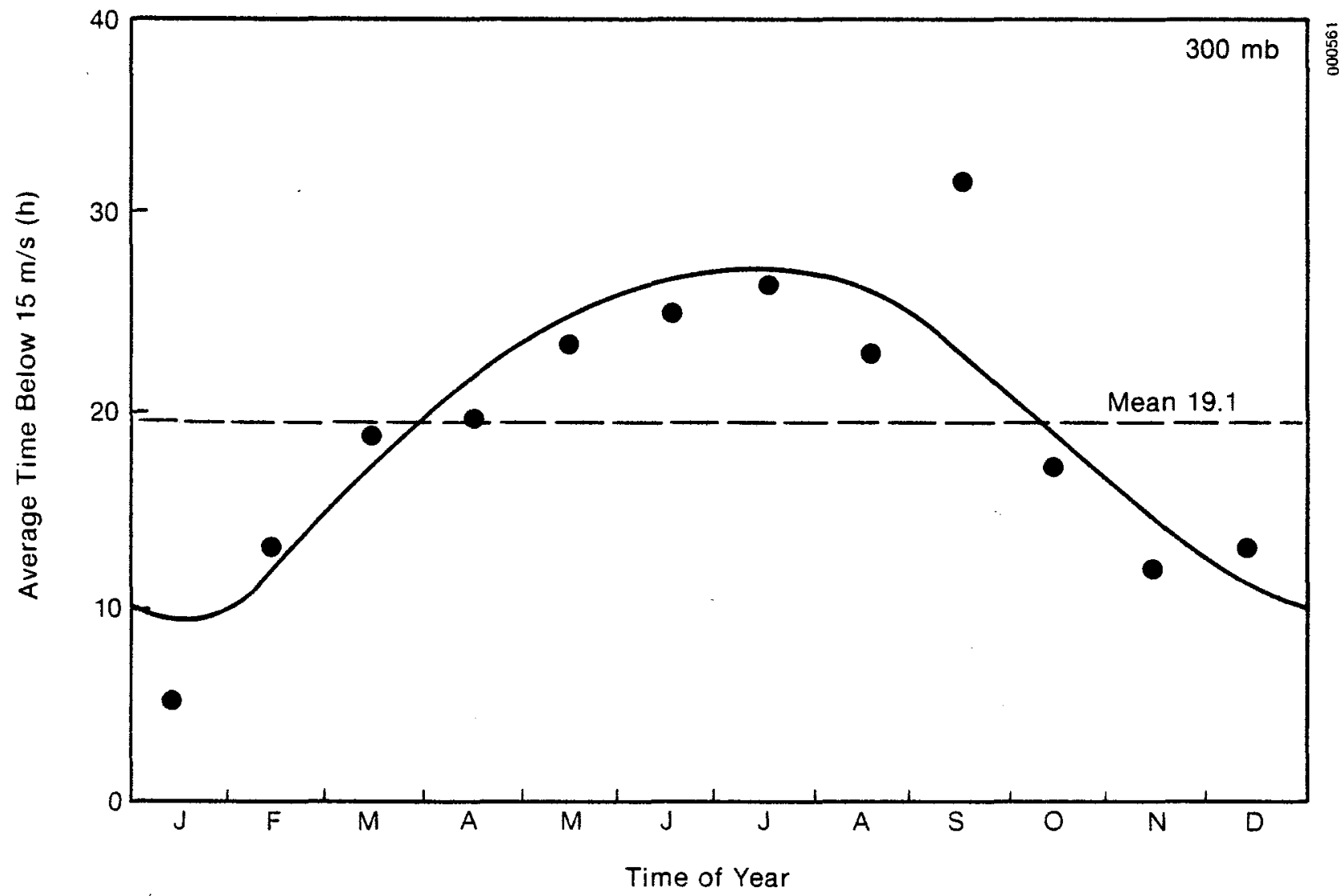

Figure 2-12. Average Period Wind is Below $15 \mathrm{~m} / \mathrm{s}$ : Portland, ME

\subsection{LIGHTNING CONDITIONS}

Possible lightning conditions are also important in the design of tethered wind energy systems. The average number of lightning days is essentially the average number of thunder days (which can be found in published charts) [9]. Our report notes that lightning conditions will be important. The occurrence of thunderstorm days is shown in Fig. 2-13. 


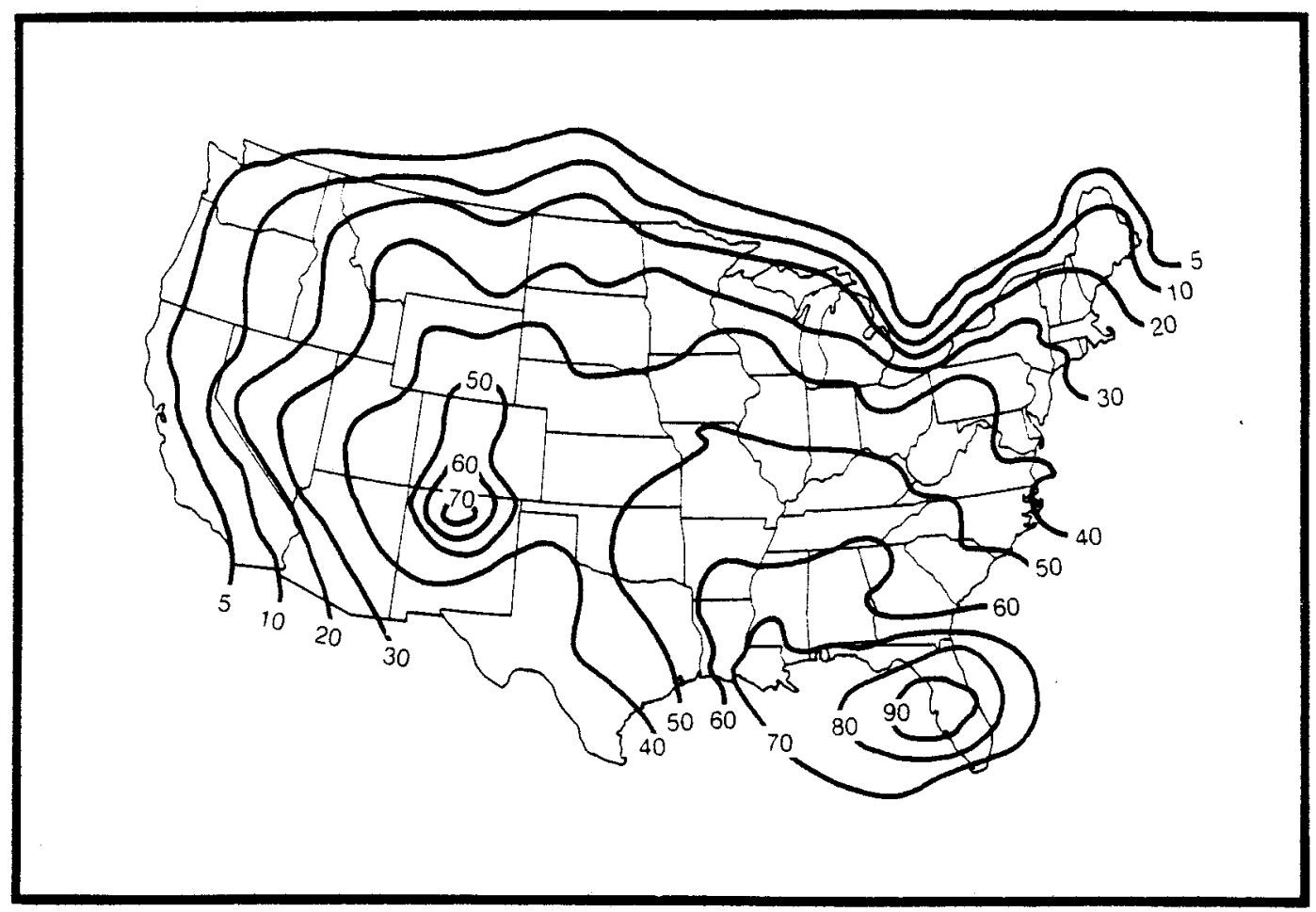

Source: Dodd. C. W. 1977 (Oct.). "Lightning Protection for a Vertical-Axis Wind Turbine." Sand 77-1241: Sandia Labs

Figure 2-13. The Annual Average Number of Thunderstorm Days

\subsection{CONCLUSIONS}

This report has attempted to analyze the relevant meteorological data that affect the design of tethered wind energy conversion systems. The United States, as we have shown, is a favorable site for this renewable energy resource. At fixed sites, the annual average power density is 10 to $16 \mathrm{~kW} / \mathrm{m}^{2}$, and over $30 \%$ of the continent. 


\section{SEPI䄅}




\section{SECTION 3.0}

\section{REFERENCES}

1. Reiter, E. R. 1963. Jet Stream Meteorology. Chicago: University of Chicago Press.

2. Atkinson, J. D. et al. The Use of Australian Upper Wind Data in the Design of an Electrical Generating Platform. Charles Kolling Laboratory, Tech, Note D-17. Sydney, Australia: University of Sydney.

3. Takle, E. S.; Brown, J. M. 1978 (Apr.). "Note on the Use of Weibull Statistics to Characterize Wind Speed Data." J. Appl. Met. Vol. 17: pp. 556-559.

4. Hennessey, J. P. 1977 (Feb.). "Some Aspects of Wind Power Statistics." J. App1. Met. Vo1. 16: pp. 119-128.

5. Hennessey, J. P. 1978. "Comparison of Weibull and Rayleigh Distributions for Estimating Wind Power Potential." Wind Eng. Vol. 2 (No. 3): pp. 156-164.

6. Cliff, W. C.; Justus, C. G.; Elderkin, C. E. Simulation of Hourly Wind Speeds for Randomly Dispersed Sites. Rep. PNL-2523. Richland, WA: Battelle-Pacific Northwest Laboratory.

7. Davenport, A. G.; Baynes, C. J. 1972. "An Approach to the Mapping of the Statistical Properties of Gradient Winds (over Canada)." Atmosphere. Vol. 10 (No. 3): pp. 80-92.

8. Maher, J. V.; Lee, D. M. 1977 (Apr.). "Upper Air Statistics - Australia." Bureau of Met. Department of Science.

9. Dodd, C. W. 1977 (Oct.). Lightning Protection for a Vertical-Axis Wind Turbine. SAND 77-1241. Albuquerque, NM: Sandia Laboratories. 


\section{SEPI*}


APPERDIX A

AVERAGE VALUES OF VELOCITY AND POWER 
SEP绻 
Table A-1. Annual Average Values of Velocity and Power

Albany, $\mathrm{NY}$

\begin{tabular}{ccc}
\hline $\begin{array}{c}\text { Altitude } \\
(\mathrm{mb})\end{array}$ & $\begin{array}{c}\text { Velocity } \\
(\overline{\mathrm{V}}, \mathrm{m} / \mathrm{s})\end{array}$ & $\left(\overrightarrow{\mathrm{P}}, \mathrm{PW} / \mathrm{m}^{2}\right)$ \\
\hline 900 & 10.1 & 1.19 \\
850 & 11.3 & 1.63 \\
700 & 15.2 & 3.10 \\
600 & 18.7 & 5.04 \\
500 & 22.6 & 7.78 \\
400 & 27.0 & 10.9 \\
300 & 31.9 & 13.4 \\
250 & 33.1 & 12.2 \\
200 & 31.4 & 8.13 \\
\hline
\end{tabular}

Table A-2. Annual Average Values of Velocity and Power

Albuquerque, NM

\begin{tabular}{ccc}
\hline $\begin{array}{c}\text { Pressure } \\
\begin{array}{c}\text { Altitude } \\
(\mathrm{mb})\end{array}\end{array}$ & $\begin{array}{c}\text { Mean } \\
\text { Velocity } \\
(\overline{\mathrm{V}}, \mathrm{m} / \mathrm{s})\end{array}$ & $\begin{array}{c}\text { Mean } \\
\text { Power } \\
\left(\overline{\mathrm{P}}, \mathrm{kw} / \mathrm{m}^{2}\right)\end{array}$ \\
\hline 900 & - & -- \\
850 & 2.50 & 0.01 \\
700 & 8.19 & 0.53 \\
600 & 11.4 & 1.31 \\
500 & 15.1 & 2.91 \\
400 & 18.8 & 4.85 \\
300 & 23.4 & 6.73 \\
250 & 26.0 & 7.31 \\
200 & 26.7 & 5.80 \\
\hline
\end{tabular}


Table A-3. Annual Average Values of Velocity and Power

Bismarck, ND

\begin{tabular}{ccc}
\hline $\begin{array}{c}\text { Altitude } \\
(\mathrm{mb})\end{array}$ & $\begin{array}{c}\text { Velocity } \\
(\overline{\mathrm{V}}, \mathrm{m} / \mathrm{s})\end{array}$ & $\left(\overline{\mathrm{P}}, \begin{array}{c}\text { Power } \\
\left.\mathrm{kW} / \mathrm{m}^{2}\right)\end{array}\right.$ \\
\hline 900 & 8.78 & 0.75 \\
850 & 9.52 & 0.97 \\
700 & 12.2 & 1.59 \\
600 & 14.9 & 2.50 \\
500 & 18.3 & 4.04 \\
400 & 22.6 & 6.51 \\
300 & 27.6 & 9.17 \\
250 & 28.7 & 8.49 \\
200 & 26.5 & 5.08 \\
\hline
\end{tabular}

Table A-4. Annual Average Values of Velocity and Power

Boise, ID

\begin{tabular}{ccc}
\hline $\begin{array}{c}\text { A1titude } \\
(\mathrm{mb})\end{array}$ & $\begin{array}{c}\text { Velocity } \\
(\overline{\mathrm{V}}, \mathrm{m} / \mathrm{s})\end{array}$ & $\left(\overline{\mathrm{P}}, \mathrm{Pow} \mathrm{kW} / \mathrm{m}^{2}\right)$ \\
\hline 900 & 4.37 & 0.11 \\
850 & 6.05 & 0.29 \\
700 & 9.56 & 0.77 \\
600 & 13.2 & 1.72 \\
500 & 17.1 & 3.29 \\
400 & 21.6 & 5.70 \\
300 & 27.0 & 8.71 \\
250 & 28.6 & 8.69 \\
200 & 26.1 & 5.16 \\
\hline
\end{tabular}


Table A-5. Annual Average Values of Velocity and Power

Brownsville, TX

\begin{tabular}{ccc}
\hline $\begin{array}{c}\text { Altitude } \\
(\mathrm{mb})\end{array}$ & $\begin{array}{c}\text { Velocity } \\
(\overline{\mathrm{V}}, \mathrm{m} / \mathrm{s})\end{array}$ & $\left(\overline{\mathrm{P}}, \begin{array}{c}\text { Power } \\
\mathrm{kW} / \mathrm{m}^{2}\end{array}\right.$ \\
\hline 900 & 8.77 & 0.77 \\
850 & 7.93 & 0.57 \\
700 & 7.4 & 0.42 \\
600 & 9.05 & 0.75 \\
500 & 11.7 & 1.46 \\
400 & 15.5 & 2.79 \\
300 & 20.9 & 5.07 \\
250 & 24.2 & 6.53 \\
200 & 26.6 & 6.75 \\
\hline
\end{tabular}

Table A-6. Annual Average Values of Velocity and Power

Buffalo, NY

\begin{tabular}{ccc}
\hline $\begin{array}{c}\text { Altitude } \\
(\mathrm{mb})\end{array}$ & $\begin{array}{c}\text { Velocity } \\
(\overline{\mathrm{V}}, \mathrm{m} / \mathrm{s})\end{array}$ & $\begin{array}{c}\text { Power } \\
\left(\overline{\mathrm{p}}, \mathrm{kW} / \mathrm{m}^{2}\right)\end{array}$ \\
\hline 900 & 9.79 & 1.20 \\
850 & 10.7 & 1.44 \\
700 & 14.5 & 2.50 \\
600 & 17.5 & 4.04 \\
500 & 21.1 & 6.39 \\
400 & 25.3 & 9.39 \\
300 & 29.8 & 11.2 \\
250 & 31.6 & 10.8 \\
200 & 29.6 & 6.8 \\
\hline
\end{tabular}


Table A-7. Annual Average Values of Velocity and Power

Caribou, ME

\begin{tabular}{ccc}
\hline $\begin{array}{c}\text { Altitude } \\
(\mathrm{mb})\end{array}$ & $\begin{array}{c}\text { Velocity } \\
(\overline{\mathrm{V}}, \mathrm{m} / \mathrm{s})\end{array}$ & $\left(\overline{\mathrm{P}}, \mathrm{P} \mathrm{kw} / \mathrm{m}^{2}\right)$ \\
\hline 900 & 10.4 & 1.22 \\
850 & 11.2 & 1.52 \\
700 & 14.6 & 2.57 \\
600 & 17.7 & 4.16 \\
500 & 21.6 & 6.72 \\
400 & 26.5 & 10.5 \\
300 & 32.5 & 14.7 \\
250 & 33.9 & 14.1 \\
200 & 30.8 & 8.35 \\
\hline
\end{tabular}

Table A-8. Annual Average Values of Velocity and Power

Charleston, SC

\begin{tabular}{ccc}
\hline $\begin{array}{c}\text { Altitude } \\
(\mathrm{mb})\end{array}$ & $\begin{array}{c}\text { Velocity } \\
(\overline{\mathrm{V}}, \mathrm{m} / \mathrm{s})\end{array}$ & $\begin{array}{c}\text { Power } \\
\left(\overline{\mathrm{p}}, \mathrm{kW} / \mathrm{m}^{2}\right)\end{array}$ \\
\hline 900 & 8.15 & 0.77 \\
850 & 8.67 & 0.89 \\
700 & 11.6 & 1.79 \\
600 & 13.9 & 2.77 \\
500 & 16.8 & 4.30 \\
400 & 20.3 & 6.19 \\
300 & 25.2 & 8.86 \\
250 & 28.5 & 10.3 \\
200 & 30.9 & 9.96 \\
\hline
\end{tabular}


Table A-9. Annual Average Values of Velocity and Power

Dayton, $\mathrm{OH}$

\begin{tabular}{ccc}
\hline $\begin{array}{c}\text { Altitude } \\
(\mathrm{mb})\end{array}$ & $\begin{array}{c}\text { Velocity } \\
(\overline{\mathrm{V}}, \mathrm{m} / \mathrm{s})\end{array}$ & $\left(\overline{\mathrm{p}}, \mathrm{power} / \mathrm{m}^{2}\right)$ \\
\hline 900 & 8.91 & 0.95 \\
850 & 9.85 & 1.24 \\
700 & 13.7 & 2.37 \\
600 & 16.9 & 3.87 \\
500 & 20.6 & 6.33 \\
400 & 25.1 & 9.84 \\
300 & 30.5 & 13.1 \\
250 & 32.9 & 13.1 \\
200 & 32.2 & 9.47 \\
\hline
\end{tabular}

Table A-10. Annual Average Values of Velocity and Power

Del Rio, TX

\begin{tabular}{ccc}
\hline $\begin{array}{c}\text { Altitude } \\
(\mathrm{mb})\end{array}$ & $\begin{array}{c}\text { Velocity } \\
(\overline{\mathrm{V}}, \mathrm{m} / \mathrm{s})\end{array}$ & $(\overline{\mathrm{P}}, \mathrm{Power}$ \\
\hline 900 & 8.09 & 0.50 \\
850 & 7.91 & 0.47 \\
700 & 8.44 & 0.61 \\
600 & 10.9 & 1.24 \\
500 & 13.9 & 2.32 \\
400 & 17.8 & 3.94 \\
300 & 23.4 & 6.58 \\
250 & 26.7 & 7.98 \\
200 & 28.4 & 7.43 \\
\hline
\end{tabular}


Table A-11. Annual Average Values of Velocity and Power

Denver, CO

\begin{tabular}{ccc}
\hline $\begin{array}{c}\text { Altitude } \\
(\mathrm{mb})\end{array}$ & $\begin{array}{c}\text { Velocity } \\
(\overline{\mathrm{V}}, \mathrm{m} / \mathrm{s})\end{array}$ & $\begin{array}{c}\text { Power } \\
\left.\mathrm{kW} / \mathrm{m}^{2}\right)\end{array}$ \\
\hline 900 & -- & -- \\
850 & -- & -- \\
700 & 7.01 & 0.41 \\
600 & 10.7 & 1.08 \\
500 & 14.5 & 2.18 \\
400 & 18.6 & 3.98 \\
300 & 23.9 & 6.40 \\
250 & 25.9 & 6.48 \\
200 & 25.5 & 4.60 \\
\hline
\end{tabular}

Table A-12. Annual Average Values of Velocity and Power

Dodge City, KS

\begin{tabular}{ccc}
\hline $\begin{array}{c}\text { Altitude } \\
(\mathrm{mb})\end{array}$ & $\begin{array}{c}\text { Velocity } \\
(\overline{\mathrm{V}}, \mathrm{m} / \mathrm{s})\end{array}$ & $\left(\overline{\mathrm{P}}, \mathrm{P} \mathrm{kW} / \mathrm{m}^{2}\right)$ \\
\hline 900 & 8.58 & 0.59 \\
850 & 10.3 & 1.21 \\
700 & 10.8 & 1.20 \\
600 & 13.1 & 1.90 \\
500 & 16.3 & 3.30 \\
400 & 20.6 & 5.66 \\
300 & 25.9 & 8.52 \\
250 & 28.5 & 9.11 \\
200 & 28.7 & 6.93 \\
\hline
\end{tabular}


Table A-13. Annual Average Values of Velocity and Power

E1y, NV

\begin{tabular}{ccc}
\hline $\begin{array}{c}\text { Altitude } \\
(\mathrm{mb})\end{array}$ & $\begin{array}{c}\text { Velocity } \\
(\overline{\mathrm{V}}, \mathrm{m} / \mathrm{s})\end{array}$ & $\begin{array}{c}\text { Power } \\
\left(\overline{\mathrm{P}}, \mathrm{kw} / \mathrm{m}^{2}\right)\end{array}$ \\
\hline 900 & -- & - \\
850 & -- & -- \\
700 & 7.29 & 0.52 \\
600 & 10.8 & 1.12 \\
500 & 14.6 & 2.41 \\
400 & 18.8 & 4.34 \\
300 & 23.4 & 6.28 \\
250 & 25.3 & 6.24 \\
200 & 24.6 & 4.30 \\
\hline
\end{tabular}

Table A-14. Annual Average Values of Velocity and Power

Fairbanks, AK

\begin{tabular}{ccc}
\hline $\begin{array}{c}\text { Altitude } \\
(\mathrm{mb})\end{array}$ & $\begin{array}{c}\text { Velocity } \\
(\overline{\mathrm{V}}, \mathrm{m} / \mathrm{s})\end{array}$ & $(\overline{\mathrm{P}}, \mathrm{Power}$ \\
\hline 900 & 5.72 & 0.28 \\
850 & 6.40 & 0.38 \\
700 & 8.31 & 0.63 \\
600 & 9.72 & 0.88 \\
500 & 12.0 & 1.58 \\
400 & 15.4 & 2.76 \\
300 & 18.3 & 3.90 \\
250 & 17.3 & 3.11 \\
200 & 14.3 & 1.23 \\
\hline
\end{tabular}


Table A-15. Annual Average Values of Velocity and Power

Fort Worth, TX

\begin{tabular}{ccc}
\hline $\begin{array}{c}\text { A1titude } \\
(\mathrm{mb})\end{array}$ & $\begin{array}{c}\text { Velocity } \\
(\overline{\mathrm{V}}, \mathrm{m} / \mathrm{s})\end{array}$ & $\left(\overline{\mathrm{P}}, \begin{array}{c}\text { Power } \\
\left.\mathrm{kW} / \mathrm{m}^{2}\right)\end{array}\right.$ \\
\hline 900 & 9.26 & 0.95 \\
850 & 9.20 & 0.90 \\
700 & 10.8 & 1.28 \\
600 & 13.1 & 2.09 \\
500 & 16.2 & 3.43 \\
400 & 20.3 & 5.58 \\
300 & 26.0 & 9.04 \\
250 & 29.4 & 10.7 \\
200 & 31.5 & 10.0 \\
\hline
\end{tabular}

Table A-16. Annual Average Values of Velocity and Power

Glasgow, MT

\begin{tabular}{ccc}
\hline $\begin{array}{c}\text { Altitude } \\
(\mathrm{mb})\end{array}$ & $\begin{array}{c}\text { Velocity } \\
(\overline{\mathrm{V}}, \mathrm{m} / \mathrm{s})\end{array}$ & $\left(\overline{\mathrm{p}}, \mathrm{Power} / \mathrm{m}^{2}\right)$ \\
\hline 900 & 7.61 & 0.48 \\
850 & 8.73 & 0.80 \\
700 & 11.7 & 1.42 \\
600 & 14.5 & 2.23 \\
500 & 17.8 & 3.58 \\
400 & 22.3 & 6.07 \\
300 & 27.1 & 8.41 \\
250 & 28.0 & 7.69 \\
200 & 25.1 & 4.31 \\
\hline
\end{tabular}


Table A-17. Annual Average Values of Velocity and Power

Great Falls, MT

\begin{tabular}{ccc}
\hline $\begin{array}{c}\text { Altitude } \\
(\mathrm{mb})\end{array}$ & $\begin{array}{c}\text { Velocity } \\
(\overline{\mathrm{V}}, \mathrm{m} / \mathrm{s})\end{array}$ & $\left(\overline{\mathrm{P}}, \begin{array}{c}\text { Power } \\
\left.\mathrm{kW} / \mathrm{m}^{2}\right)\end{array}\right.$ \\
\hline 900 & 3.13 & 0.30 \\
850 & .8 .40 & 0.72 \\
700 & 10.7 & 1.31 \\
600 & 13.7 & 2.08 \\
500 & 17.3 & 3.43 \\
400 & 22.0 & 6.11 \\
300 & 27.3 & 8.99 \\
250 & 28.2 & 8.20 \\
200 & 25.2 & 4.53 \\
\hline
\end{tabular}

Table A-18. Annual Average Values of Velocity and Power

Green Bay, WI

\begin{tabular}{ccc}
\hline $\begin{array}{c}\text { Altitude } \\
(\mathrm{mb})\end{array}$ & $\begin{array}{c}\text { Velocity } \\
(\overline{\mathrm{V}}, \mathrm{m} / \mathrm{s})\end{array}$ & $\begin{array}{c}\text { Power } \\
\left(\overline{\mathrm{P}}, \mathrm{kW} / \mathrm{m}^{2}\right)\end{array}$ \\
\hline 900 & 9.25 & 0.92 \\
850 & 9.67 & 0.99 \\
700 & 13.0 & 1.81 \\
600 & 16.0 & 3.00 \\
500 & 19.4 & 4.85 \\
400 & 24.0 & 7.97 \\
300 & 30.0 & 11.53 \\
250 & 31.1 & 10.87 \\
200 & 28.8 & 6.71 \\
\hline
\end{tabular}


Table A-19. Annual Average Values of Velocity and Power

Greensboro, NC

\begin{tabular}{ccc}
\hline $\begin{array}{c}\text { Altitude } \\
(\mathrm{mb})\end{array}$ & $\begin{array}{c}\text { Velocity } \\
(\overline{\mathrm{V}}, \mathrm{m} / \mathrm{s})\end{array}$ & $\begin{array}{c}\text { Power } \\
\left(\overline{\mathrm{P}}, \mathrm{kW} / \mathrm{m}^{2}\right)\end{array}$ \\
\hline 900 & 8.34 & 0.76 \\
850 & 9.13 & 1.02 \\
700 & 13.0 & 2.23 \\
600 & 15.8 & 3.48 \\
500 & 19.3 & 5.48 \\
400 & 23.3 & 8.03 \\
300 & 27.9 & 10.2 \\
250 & 30.3 & 10.7 \\
200 & 30.8 & 8.61 \\
\hline
\end{tabular}

Table A-20. Annual Average Values of Velocity and Power

Guadalupe Island, Mexico

\begin{tabular}{ccc}
\hline $\begin{array}{c}\text { Altitude } \\
(\mathrm{mb})\end{array}$ & $\begin{array}{c}\text { Velocity } \\
(\overline{\mathrm{V}}, \mathrm{m} / \mathrm{s})\end{array}$ & $\left(\overline{\mathrm{P}}, \mathrm{PW} / \mathrm{m}^{2}\right)$ \\
\hline 900 & 4.31 & 0.15 \\
850 & 5.48 & 0.21 \\
700 & 7.45 & 0.45 \\
600 & 9.00 & 0.75 \\
500 & 10.7 & 1.08 \\
400 & 12.8 & 1.50 \\
300 & 16.1 & 2.25 \\
250 & 17.9 & 2.69 \\
200 & 19.0 & 2.63 \\
\hline
\end{tabular}


Table A-21. Annual Average Values of Velocity and Power

Hilo, HI

\begin{tabular}{ccc}
\hline $\begin{array}{c}\text { A1titude } \\
(\mathrm{mb})\end{array}$ & $\begin{array}{c}\text { Velocity } \\
(\overline{\mathrm{V}}, \mathrm{m} / \mathrm{s})\end{array}$ & $\begin{array}{c}\text { Power } \\
\left(\overline{\mathrm{P}}, \mathrm{kW} / \mathrm{m}^{2}\right)\end{array}$ \\
\hline 900 & 4.27 & 0.096 \\
850 & 4.16 & 0.088 \\
700 & 5.64 & 0.191 \\
600 & 6.02 & 0.242 \\
500 & 7.58 & 0.413 \\
400 & 10.9 & 0.900 \\
300 & 17.2 & 2.47 \\
250 & 21.7 & 3.95 \\
200 & 25.0 & 4.80 \\
\hline
\end{tabular}

Table A-22. Annual Average Values of Velocity and Power

Huntington, WV

\begin{tabular}{ccc}
\hline $\begin{array}{c}\text { Altitude } \\
(\mathrm{mb})\end{array}$ & $\begin{array}{c}\text { Velocity } \\
(\overline{\mathrm{V}}, \mathrm{m} / \mathrm{s})\end{array}$ & $\begin{array}{c}\text { Power } \\
\left(\overline{\mathrm{P}}, \mathrm{kW} / \mathrm{m}^{2}\right)\end{array}$ \\
\hline 900 & 8.18 & 0.77 \\
850 & 9.32 & 1.06 \\
700 & 13.6 & 2.37 \\
600 & 16.9 & 3.96 \\
500 & 20.5 & 6.32 \\
400 & 24.7 & 9.13 \\
300 & 30.3 & 12.8 \\
250 & 32.9 & 13.1 \\
200 & 32.8 & 10.1 \\
\hline
\end{tabular}


Table A-23. Annual Average Values of Velocity and Power

International Falls, $: \mathbb{N}$

\begin{tabular}{ccc}
\hline $\begin{array}{c}\text { Altitude } \\
(\mathrm{mb})\end{array}$ & $\begin{array}{c}\text { Velocity } \\
(\overline{\mathrm{V}}, \mathrm{m} / \mathrm{s})\end{array}$ & $\left(\overline{\mathrm{P}}, \mathrm{kW} / \mathrm{m}^{2}\right)$ \\
\hline 900 & 8.64 & 0.73 \\
850 & 9.38 & 0.92 \\
700 & 12.2 & 1.50 \\
600 & 15.1 & 2.45 \\
500 & 18.4 & 4.00 \\
400 & 22.9 & 6.70 \\
300 & 27.6 & 9.00 \\
250 & 28.6 & 8.20 \\
200 & 25.8 & 4.64 \\
\hline
\end{tabular}

Table A-24. Annual Average Values of Velocity and Power

Lander, WY

\begin{tabular}{ccc}
\hline $\begin{array}{c}\text { Altitude } \\
(\mathrm{mb})\end{array}$ & $\begin{array}{c}\text { Velocity } \\
(\overline{\mathrm{V}}, \mathrm{m} / \mathrm{s})\end{array}$ & $\begin{array}{c}\text { Power } \\
\left(\overline{\mathrm{P}}, \mathrm{kW} / \mathrm{m}^{2}\right)\end{array}$ \\
\hline 900 & -- & -- \\
850 & -- & -- \\
700 & 6.83 & 0.42 \\
600 & 12.3 & 1.56 \\
500 & 15.9 & 2.87 \\
400 & 20.0 & 4.72 \\
300 & 25.4 & 7.49 \\
250 & 27.0 & 7.31 \\
200 & 25.5 & 4.79 \\
\hline
\end{tabular}


Table A-25. Annual Average Values of Velocity and Power

Little Rock, AR

\begin{tabular}{ccc}
\hline $\begin{array}{c}\text { A1titude } \\
(\mathrm{mb})\end{array}$ & $\begin{array}{c}\text { Velocity } \\
(\overline{\mathrm{V}}, \mathrm{m} / \mathrm{s})\end{array}$ & $\begin{array}{c}\text { Power } \\
\left(\overline{\mathrm{P}}, \mathrm{kW} / \mathrm{m}^{2}\right)\end{array}$ \\
\hline 900 & 8.58 & 0.86 \\
850 & 9.20 & 1.02 \\
700 & 12.0 & 1.78 \\
600 & 14.7 & 2.92 \\
500 & 17.7 & 4.48 \\
400 & 21.5 & 6.68 \\
300 & 26.8 & 9.68 \\
250 & 29.9 & 11.1 \\
200 & 31.4 & 9.95 \\
\hline
\end{tabular}

Table A-26. Annual Average Values of Velocity and Power

Medford, OR

\begin{tabular}{ccc}
\hline $\begin{array}{c}\text { Altitude } \\
(\mathrm{mb})\end{array}$ & $\begin{array}{c}\text { Velocity } \\
(\overline{\mathrm{V}}, \mathrm{m} / \mathrm{s})\end{array}$ & $\left(\overline{\mathrm{P}}, \mathrm{Power} / \mathrm{m}^{2}\right)$ \\
\hline 900 & 3.63 & 0.087 \\
850 & 4.87 & 0.19 \\
700 & 10.9 & 1.42 \\
600 & 14.2 & 2.49 \\
500 & 18.0 & 4.25 \\
400 & 22.3 & 6.70 \\
300 & 26.8 & 9.05 \\
250 & 28.1 & 8.56 \\
200 & 26.1 & 5.19 \\
\hline
\end{tabular}


Table A-27. Annual Average Values of Velocity and Power

Midland, TX

\begin{tabular}{ccc}
\hline $\begin{array}{c}\text { Altitude } \\
(\mathrm{mb})\end{array}$ & $\begin{array}{c}\text { Velocity } \\
(\overline{\mathrm{V}}, \mathrm{m} / \mathrm{s})\end{array}$ & $\begin{array}{c}\text { Power } \\
\left(\overline{\mathrm{P}}, \mathrm{kW} / \mathrm{m}^{2}\right)\end{array}$ \\
\hline 900 & 6.63 & 0.25 \\
850 & 8.77 & 0.63 \\
700 & 9.42 & 0.87 \\
600 & 12.4 & 1.72 \\
500 & 15.5 & 3.12 \\
400 & 19.4 & 5.14 \\
300 & 24.9 & 7.98 \\
250 & 27.9 & 9.18 \\
200 & 29.1 & 8.03 \\
\hline
\end{tabular}

Table A-28. Annual Average Values of Velocity and Power

Montgomery, AL

\begin{tabular}{ccc}
\hline $\begin{array}{c}\text { Altitude } \\
(\mathrm{mb})\end{array}$ & $\begin{array}{c}\text { Velocity } \\
(\overline{\mathrm{V}}, \mathrm{m} / \mathrm{s})\end{array}$ & $\left(\overline{\mathrm{P}}, \mathrm{Power} / \mathrm{m}^{2}\right)$ \\
\hline 900 & 7.57 & 0.60 \\
850 & 8.28 & 0.74 \\
700 & 11.1 & 1.59 \\
600 & 13.4 & 2.52 \\
500 & 16.4 & 3.96 \\
400 & 19.9 & 5.83 \\
300 & 24.7 & 8.44 \\
250 & 27.8 & 9.80 \\
200 & 30.1 & 9.48 \\
\hline
\end{tabular}


Table A-29. Annual Average Values of Velocity and Power

Nashville, TN

\begin{tabular}{ccc}
\hline $\begin{array}{c}\text { Altitude } \\
(\mathrm{mb})\end{array}$ & $\begin{array}{c}\text { Velocity } \\
(\overline{\mathrm{V}}, \mathrm{m} / \mathrm{s})\end{array}$ & $\begin{array}{c}\text { Power } \\
\left(\overline{\mathrm{P}}, \mathrm{kW} / \mathrm{m}^{2}\right)\end{array}$ \\
\hline 900 & 8.48 & 0.39 \\
850 & 9.31 & 1.09 \\
700 & 13.0 & 2.20 \\
600 & 15.8 & 3.59 \\
500 & 19.2 & 5.63 \\
400 & 23.3 & 8.33 \\
300 & 28.8 & 11.6 \\
250 & 31.8 & 12.5 \\
200 & 32.5 & 10.4 \\
\hline
\end{tabular}

Table A-30. Annual Average Values of Velocity and Power

New York, NY

\begin{tabular}{ccc}
\hline $\begin{array}{c}\text { Altitude } \\
(\mathrm{mb})\end{array}$ & $\begin{array}{c}\text { Velocity } \\
(\overline{\mathrm{V}}, \mathrm{m} / \mathrm{s})\end{array}$ & $\left(\overline{\mathrm{P}}, \mathrm{Power} / \mathrm{m}^{2}\right)$ \\
\hline 900 & 9.94 & 1.28 \\
850 & 10.7 & 1.46 \\
700 & 15.0 & 3.03 \\
600 & 18.5 & 1.85 \\
500 & 22.4 & 7.98 \\
400 & 27.5 & 12.3 \\
300 & 33.2 & 16.2 \\
250 & 35.5 & 16.3 \\
200 & 34.6 & 11.6 \\
\hline
\end{tabular}


Table A-31. Annual Average Values of Velocity and Power

North Platte, NE

\begin{tabular}{ccc}
\hline $\begin{array}{c}\text { Altitude } \\
(\mathrm{mb})\end{array}$ & $\begin{array}{c}\text { Velocity } \\
(\overline{\mathrm{V}}, \mathrm{m} / \mathrm{s})\end{array}$ & $\left(\overline{\mathrm{P}}, \mathrm{Pow} / \mathrm{m}^{2}\right)$ \\
\hline 900 & 6.20 & 0.25 \\
850 & 9.74 & 0.96 \\
700 & 11.4 & 1.34 \\
600 & 13.9 & 2.05 \\
500 & 16.9 & 3.24 \\
400 & 20.9 & 5.51 \\
300 & 26.1 & 8.29 \\
250 & 28.3 & 8.55 \\
200 & 27.6 & 6.04 \\
\hline
\end{tabular}

Table A-32. Annual Average Values of Velocity and Power

Oakland, CA

\begin{tabular}{|c|c|c|}
\hline $\begin{array}{l}\text { Altitude } \\
\text { (mb) }\end{array}$ & $\begin{array}{l}\text { Velocity } \\
(\bar{V}, \mathrm{~m} / \mathrm{s})\end{array}$ & $\left(\overline{\mathrm{P}}, \mathrm{kN} / \mathrm{m}^{2}\right)$ \\
\hline 900 & 6.18 & 0.33 \\
\hline 850 & 6.80 & 0.43 \\
\hline 700 & 9.99 & 1.11 \\
\hline 600 & 13.0 & 2.12 \\
\hline 500 & 16.3 & 3.54 \\
\hline 400 & 20.3 & 5.43 \\
\hline 300 & 25.1 & 7.62 \\
\hline 250 & 27.0 & 7.57 \\
\hline 200 & 26.3 & 5.44 \\
\hline
\end{tabular}


Table A-33. Annual Average Values of Velocity and Power

Oklahoma City, OK

\begin{tabular}{ccc}
\hline $\begin{array}{c}\text { Altitude } \\
(\mathrm{mb})\end{array}$ & $\begin{array}{c}\text { Velocity } \\
(\overline{\mathrm{V}}, \mathrm{m} / \mathrm{s})\end{array}$ & $\left(\overline{\mathrm{P}}, \mathrm{pW} / \mathrm{m}^{2}\right)$ \\
\hline 900 & 10.0 & 1.21 \\
850 & 9.9 & 1.18 \\
700 & 11.2 & 1.49 \\
600 & 13.6 & 2.41 \\
500 & 15.5 & 3.84 \\
400 & 20.4 & 5.80 \\
300 & 25.6 & 8.04 \\
250 & 27.8 & 8.59 \\
200 & 27.8 & 6.94 \\
\hline
\end{tabular}

Table A-34. Annual Average Values of Velocity and Power

Omaha, NE

\begin{tabular}{ccc}
\hline $\begin{array}{c}\text { Altitude } \\
(\mathrm{mb})\end{array}$ & $\begin{array}{c}\text { Velocity } \\
(\overline{\mathrm{V}}, \mathrm{m} / \mathrm{s})\end{array}$ & $\left(\overline{\mathrm{P}}, \mathrm{kW} / \mathrm{m}^{2}\right)$ \\
\hline 900 & 10.3 & 1.67 \\
850 & 10.5 & 3.12 \\
700 & 12.6 & 1.78 \\
600 & 15.4 & 2.96 \\
500 & 18.6 & 4.72 \\
400 & 22.8 & 7.66 \\
300 & 28.1 & 10.8 \\
250 & 30.1 & 10.5 \\
200 & 29.0 & 6.96 \\
\hline
\end{tabular}


Table A-35. Annual Average Values of Velocity and Power

Peoria, IL

\begin{tabular}{ccc}
\hline $\begin{array}{c}\text { Altitude } \\
(\mathrm{mb})\end{array}$ & $\begin{array}{c}\text { Velocity } \\
(\overline{\mathrm{V}}, \mathrm{m} / \mathrm{s})\end{array}$ & $\begin{array}{c}\text { Power } \\
\left(\overline{\mathrm{P}}, \mathrm{kW} / \mathrm{m}^{2}\right)\end{array}$ \\
\hline 900 & 9.33 & 1.00 \\
850 & 9.87 & 1.12 \\
700 & 13.4 & 2.13 \\
600 & 16.5 & 3.59 \\
500 & 19.9 & 5.72 \\
400 & 24.3 & 8.86 \\
300 & 29.8 & 12.31 \\
250 & 32.1 & 12.35 \\
200 & 31.4 & 8.83 \\
\hline
\end{tabular}

Table A-36. Annual Average Values of Velocity and Power

Pittsburgh, PA

\begin{tabular}{ccc}
\hline $\begin{array}{c}\text { Altitude } \\
(\mathrm{mb})\end{array}$ & $\begin{array}{c}\text { Velocity } \\
(\overline{\mathrm{V}}, \mathrm{m} / \mathrm{s})\end{array}$ & $\left(\overline{\mathrm{P}}, \begin{array}{c}\text { Power } \\
\left.\mathrm{kW} / \mathrm{m}^{2}\right)\end{array}\right.$ \\
\hline 900 & 8.57 & 0.79 \\
850 & 9.89 & 1.15 \\
700 & 14.5 & 2.640 \\
600 & 17.8 & 4.30 \\
500 & 21.6 & 6.91 \\
400 & 26.3 & 10.8 \\
300 & 32.2 & 14.9 \\
250 & 34.4 & 14.8 \\
200 & 33.1 & 10.0 \\
\hline
\end{tabular}


Table A-37. Annual Average Values of Velocity and Power

Portland, ME

\begin{tabular}{ccc}
\hline $\begin{array}{c}\text { A1titude } \\
(\mathrm{mb})\end{array}$ & $\begin{array}{c}\text { Velocity } \\
(\overline{\mathrm{V}}, \mathrm{m} / \mathrm{s})\end{array}$ & $(\overline{\mathrm{P}}, \mathrm{Power}$ \\
\hline 900 & $\left.\mathrm{~kW} / \mathrm{m}^{2}\right)$ \\
850 & 10.42 & 1.11 \\
700 & 14.8 & 1.36 \\
600 & 18.4 & 2.84 \\
500 & 22.5 & 4.67 \\
400 & 27.6 & 7.53 \\
300 & 32.8 & 11.38 \\
250 & 33.9 & 14.1 \\
200 & 31.2 & 12.9 \\
\hline
\end{tabular}

Table A-38. Annual Average Values of Velocity and Power

Rapid City, SD

\begin{tabular}{ccc}
\hline $\begin{array}{c}\text { Altitude } \\
(\mathrm{mb})\end{array}$ & $\begin{array}{c}\text { Velocity } \\
(\overline{\mathrm{V}}, \mathrm{m} / \mathrm{s})\end{array}$ & $\left(\overline{\mathrm{P}}, \begin{array}{c}\text { Power } \\
\left.\mathrm{kW} / \mathrm{m}^{2}\right)\end{array}\right.$ \\
\hline 900 & 5.27 & 0.22 \\
850 & 8.31 & 0.73 \\
700 & 12.3 & 1.23 \\
600 & 19.4 & 1.94 \\
500 & 17.1 & 3.17 \\
400 & 21.3 & 5.23 \\
300 & 26.2 & 7.74 \\
250 & 27.7 & 7.60 \\
200 & 26.1 & 4.82 \\
\hline
\end{tabular}


Table A-39. Annual Average Values of Velocity and Power

St. Cloud, MN

\begin{tabular}{ccc}
\hline $\begin{array}{c}\text { Altitude } \\
(\mathrm{mb})\end{array}$ & $\begin{array}{c}\text { Velocity } \\
(\overline{\mathrm{V}}, \mathrm{m} / \mathrm{s})\end{array}$ & $\left(\overline{\mathrm{P}}, \mathrm{Power} / \mathrm{m}^{2}\right)$ \\
\hline 900 & 9.19 & 0.88 \\
850 & 9.66 & 0.98 \\
700 & 12.7 & 1.69 \\
600 & 15.4 & 2.70 \\
500 & 18.7 & 4.29 \\
400 & 22.9 & 6.82 \\
300 & 28.3 & 9.88 \\
250 & 29.8 & 9.42 \\
200 & 27.5 & 5.61 \\
\hline
\end{tabular}

Table A-40. Annual Average Values of Velocity and Power

Salem, IL

\begin{tabular}{ccc}
\hline $\begin{array}{c}\text { Altitude } \\
(\mathrm{mb})\end{array}$ & $\begin{array}{c}\text { Velocity } \\
(\overline{\mathrm{V}}, \mathrm{m} / \mathrm{s})\end{array}$ & $\left(\overline{\mathrm{P}}, \mathrm{Power} / \mathrm{m}^{2}\right)$ \\
\hline 900 & 9.24 & 1.02 \\
850 & 9.86 & 1.16 \\
700 & 13.4 & 2.19 \\
600 & 16.2 & 3.56 \\
500 & 19.5 & 5.55 \\
400 & 23.6 & 8.24 \\
300 & 28.0 & 10.2 \\
250 & 30.0 & 10.1 \\
200 & 29.4 & 7.39 \\
\hline
\end{tabular}


Table A-41. Annual Average Values of Velocity and Power

Salem, OR

\begin{tabular}{ccc}
\hline $\begin{array}{c}\text { Altitude } \\
(\mathrm{mb})\end{array}$ & $\begin{array}{c}\text { Velocity } \\
(\overline{\mathrm{V}}, \mathrm{m} / \mathrm{s})\end{array}$ & $\begin{array}{c}\text { Power } \\
\left(\overline{\mathrm{P}}, \mathrm{kW} / \mathrm{m}^{2}\right)\end{array}$ \\
\hline 900 & 6.91 & 0.63 \\
850 & 7.96 & 0.89 \\
700 & 11.9 & 1.63 \\
600 & 15.0 & 2.59 \\
500 & 18.8 & 4.44 \\
400 & 23.2 & 7.15 \\
300 & 27.8 & 9.31 \\
250 & 28.3 & 8.05 \\
200 & 25.3 & 4.40 \\
\hline
\end{tabular}

Table A-42. Annual Average Values of Velocity and Power

Salt Lake City, UT

\begin{tabular}{ccc}
\hline $\begin{array}{c}\text { Altitude } \\
(\mathrm{mb})\end{array}$ & $\begin{array}{c}\text { Velocity } \\
(\overline{\mathrm{V}}, \mathrm{m} / \mathrm{s})\end{array}$ & $\left(\overline{\mathrm{P}}, \mathrm{kw} / \mathrm{m}^{2}\right)$ \\
\hline 900 & -- & - \\
850 & 4.79 & 0.15 \\
700 & 7.65 & 0.41 \\
600 & 11.6 & 1.15 \\
500 & 15.6 & 2.61 \\
400 & 20.0 & 4.87 \\
300 & 24.8 & 7.32 \\
250 & 26.7 & 7.50 \\
200 & 25.6 & 4.94 \\
\hline
\end{tabular}


Table A-43. Annual Average Values of Velocity and Power

San Nichols Island, CA

\begin{tabular}{ccc}
\hline $\begin{array}{c}\text { Altitude } \\
(\mathrm{mb})\end{array}$ & $\begin{array}{c}\text { Velocity } \\
(\overline{\mathrm{V}}, \mathrm{m} / \mathrm{s})\end{array}$ & $\left(\overline{\mathrm{P}}, \mathrm{PW} / \mathrm{m}^{2}\right)$ \\
\hline 900 & 5.05 & 0.23 \\
850 & 5.72 & 0.29 \\
700 & 8.50 & 0.75 \\
600 & 10.7 & 1.41 \\
500 & 13.0 & 2.16 \\
400 & 16.0 & 3.16 \\
300 & 20.6 & 4.53 \\
250 & 22.7 & 5.00 \\
200 & 23.4 & 4.14 \\
\hline
\end{tabular}

Table A-44. Annual Average Values of Velocity and Power

Sault Ste. Marie, MI

\begin{tabular}{ccc}
\hline $\begin{array}{c}\text { Altitude } \\
(\mathrm{mb})\end{array}$ & $\begin{array}{c}\text { Velocity } \\
(\overline{\mathrm{V}}, \mathrm{m} / \mathrm{s})\end{array}$ & $\left(\overline{\mathrm{P}}, \begin{array}{c}\text { Power } \\
\left.\mathrm{kW} / \mathrm{m}^{2}\right)\end{array}\right.$ \\
\hline 900 & 9.13 & 0.85 \\
850 & 9.82 & 1.00 \\
700 & 13.2 & 1.92 \\
600 & 16.0 & 2.99 \\
500 & 19.4 & 4.81 \\
400 & 23.8 & 7.87 \\
300 & 29.5 & 11.70 \\
250 & 31.1 & 11.29 \\
200 & 28.7 & 6.95 \\
\hline
\end{tabular}


Table A-45. Annual Average Values of Velocity and Power

Shreveport, LA

\begin{tabular}{ccc}
\hline $\begin{array}{c}\text { Altitude } \\
(\mathrm{mb})\end{array}$ & $\begin{array}{c}\text { Velocity } \\
(\overline{\mathrm{V}}, \mathrm{m} / \mathrm{s})\end{array}$ & $\begin{array}{c}\text { Power } \\
\left(\overline{\mathrm{P}}, \mathrm{kW} / \mathrm{m}^{2}\right)\end{array}$ \\
\hline 900 & 8.44 & 0.84 \\
850 & 9.03 & 0.99 \\
700 & 11.3 & 1.49 \\
600 & 13.8 & 2.44 \\
500 & 16.7 & 3.84 \\
400 & 20.5 & 5.99 \\
300 & 25.4 & 8.24 \\
250 & 28.4 & 9.52 \\
200 & 29.9 & 8.62 \\
\hline
\end{tabular}

Table A-46. Annual Average Values of Velocity and Power

Spokane, WA

\begin{tabular}{ccc}
\hline $\begin{array}{c}\text { Altitude } \\
(\mathrm{mb})\end{array}$ & $\begin{array}{c}\text { Velocity } \\
(\overline{\mathrm{V}}, \mathrm{m} / \mathrm{s})\end{array}$ & $\begin{array}{c}\text { Power } \\
\left(\overline{\mathrm{P}}, \mathrm{kW} / \mathrm{m}^{2}\right)\end{array}$ \\
\hline 900 & 6.32 & 0.34 \\
850 & 7.34 & 0.61 \\
700 & 10.0 & 0.98 \\
600 & 13.7 & 2.05 \\
500 & 17.7 & 3.77 \\
400 & 22.8 & 6.73 \\
300 & 28.7 & 10.6 \\
250 & 29.6 & 10.0 \\
200 & 26.3 & 5.57 \\
\hline
\end{tabular}


Table A-47. Annual Average Values of Velocity and Power

Tampa, FL

\begin{tabular}{ccc}
\hline $\begin{array}{c}\text { Altitude } \\
\text { (mb) }\end{array}$ & $\begin{array}{c}\text { Velocity } \\
(\overline{\mathrm{V}}, \mathrm{m} / \mathrm{s})\end{array}$ & $\begin{array}{c}\text { Power } \\
\left(\overline{\mathrm{p}}, \mathrm{kW} / \mathrm{m}^{2}\right)\end{array}$ \\
\hline 900 & 6.43 & 0.35 \\
850 & 6.57 & 0.39 \\
700 & 7.76 & 0.67 \\
600 & 9.56 & 1.08 \\
500 & 12.1 & 1.74 \\
400 & 15.2 & 2.70 \\
300 & 19.4 & 4.24 \\
250 & 22.4 & 5.26 \\
200 & 25.2 & 5.58 \\
\hline
\end{tabular}

Table A-48. Annual Average Values of Velocity and Power

Topeka, KS

\begin{tabular}{ccc}
\hline $\begin{array}{c}\text { Altitude } \\
(\mathrm{mb})\end{array}$ & $\begin{array}{c}\text { Velocity } \\
(\overline{\mathrm{V}}, \mathrm{m} / \mathrm{s})\end{array}$ & $\begin{array}{c}\text { Power } \\
\left(\overline{\mathrm{P}}, \mathrm{kW} / \mathrm{m}^{2}\right)\end{array}$ \\
\hline 900 & 9.70 & 1.08 \\
850 & 9.96 & 1.14 \\
700 & 12.4 & 1.75 \\
600 & 15.0 & 2.76 \\
500 & 13.0 & 4.30 \\
400 & 22.0 & 6.80 \\
300 & 26.9 & 9.25 \\
250 & 29.0 & 9.24 \\
200 & 28.6 & 6.55 \\
\hline
\end{tabular}


Table A-49. Annual Average Values of Velocity and Power

Tucson, AZ

\begin{tabular}{ccc}
\hline $\begin{array}{c}\text { Pressure } \\
\begin{array}{c}\text { Altitude } \\
(\mathrm{mb})\end{array}\end{array}$ & $\begin{array}{c}\text { Mean } \\
\text { Velocity } \\
(\overline{\mathrm{V}}, \mathrm{m} / \mathrm{s})\end{array}$ & $\begin{array}{c}\text { Mean } \\
\text { Power } \\
\left(\overline{\mathrm{P}}, \mathrm{kW} / \mathrm{m}^{2}\right)\end{array}$ \\
\hline 900 & 4.47 & 0.13 \\
850 & 5.12 & 0.19 \\
700 & 7.68 & 0.50 \\
600 & 10.7 & 1.23 \\
500 & 14.0 & 2.54 \\
400 & 17.9 & 4.43 \\
300 & 22.8 & 6.44 \\
250 & 25.6 & 7.49 \\
200 & 26.7 & 6.37 \\
\hline
\end{tabular}

Table A-50. Annual Average Values of Velocity and Power

Wallops Island, VA

\begin{tabular}{ccc}
\hline $\begin{array}{c}\text { Altitude } \\
(\mathrm{mb})\end{array}$ & $\begin{array}{c}\text { Velocity } \\
(\overline{\mathrm{V}}, \mathrm{m} / \mathrm{s})\end{array}$ & $\begin{array}{c}\text { Power } \\
\left(\overline{\mathrm{P}}, \mathrm{kW} / \mathrm{m}^{2}\right)\end{array}$ \\
\hline 900 & 9.71 & 1.20 \\
850 & 10.2 & 1.24 \\
700 & 14.0 & 2.43 \\
600 & 17.2 & 4.08 \\
500 & 20.7 & 6.37 \\
400 & 24.9 & 9.24 \\
300 & 29.7 & 12.1 \\
250 & 32.0 & 12.2 \\
200 & 32.1 & 9.67 \\
\hline
\end{tabular}


Table A-51. Annual Average Values of Velocity and Power

Waycross, GA

\begin{tabular}{ccc}
\hline $\begin{array}{c}\text { Altitude } \\
(\mathrm{mb})\end{array}$ & $\begin{array}{c}\text { Velocity } \\
(\overline{\mathrm{V}}, \mathrm{m} / \mathrm{s})\end{array}$ & $\left(\overline{\mathrm{P}}, \mathrm{PW} / \mathrm{m}^{2}\right)$ \\
\hline 900 & 7.50 & 0.60 \\
850 & 7.92 & 0.71 \\
700 & 10.4 & 1.41 \\
600 & 12.5 & 2.23 \\
500 & 15.3 & 3.45 \\
400 & 18.8 & 5.20 \\
300 & 23.5 & 7.31 \\
250 & 26.6 & 8.54 \\
200 & 29.2 & 8.58 \\
\hline
\end{tabular}

Table A-52. Annual Average Values of Velocity and Power

Winnemucca, NV

\begin{tabular}{ccc}
\hline $\begin{array}{c}\text { Altitude } \\
(\mathrm{mb})\end{array}$ & $\begin{array}{c}\text { Velocity } \\
(\overline{\mathrm{V}}, \mathrm{m} / \mathrm{s})\end{array}$ & $\begin{array}{c}\text { Power } \\
\left(\overline{\mathrm{P}}, \mathrm{kW} / \mathrm{m}^{2}\right)\end{array}$ \\
\hline 900 & -- & -- \\
850 & 4.52 & 0.11 \\
700 & 8.21 & 0.64 \\
600 & 12.2 & 1.57 \\
500 & 16.1 & 3.08 \\
400 & 19.9 & 4.84 \\
300 & 24.9 & 7.22 \\
250 & 26.1 & 6.76 \\
200 & 24.6 & 4.28 \\
\hline
\end{tabular}


Table A-53. Annual Average Values of Velocity and Power

Winslow, $A Z$

\begin{tabular}{ccc}
\hline $\begin{array}{c}\text { Altitude } \\
(\mathrm{mb})\end{array}$ & $\begin{array}{c}\text { Velocity } \\
(\overline{\mathrm{V}}, \mathrm{m} / \mathrm{s})\end{array}$ & $\begin{array}{c}\text { Power } \\
\left(\overline{\mathrm{P}}, \mathrm{kW} / \mathrm{m}^{2}\right)\end{array}$ \\
\hline 900 & -- & - \\
850 & 3.13 & 0.05 \\
700 & 8.31 & 0.68 \\
600 & 10.7 & 1.22 \\
500 & 14.0 & 2.32 \\
400 & 18.1 & 4.29 \\
300 & 23.3 & 6.59 \\
250 & 25.6 & 7.00 \\
200 & 25.8 & 5.27 \\
\hline
\end{tabular}

Table A-54. Annual Average Values of Velocity and Power

Yucca Flats, NV

\begin{tabular}{ccc}
\hline $\begin{array}{c}\text { A1titude } \\
(\mathrm{mb})\end{array}$ & $\begin{array}{c}\text { Velocity } \\
(\overline{\mathrm{V}}, \mathrm{m} / \mathrm{s})\end{array}$ & $\begin{array}{c}\text { Power } \\
\left(\overline{\mathrm{P}}, \mathrm{kW} / \mathrm{m}^{2}\right)\end{array}$ \\
\hline 900 & -- & - \\
850 & 5.06 & 0.19 \\
700 & 7.81 & 0.50 \\
600 & 10.4 & 1.11 \\
500 & 14.1 & 2.39 \\
400 & 17.9 & 3.97 \\
300 & 22.4 & 5.47 \\
250 & 24.3 & 5.48 \\
200 & 24.1 & 4.17 \\
\hline
\end{tabular}




\section{S=P隣}




\section{APPENDIX B}

APPLICATION OF U.S. UPPER WIND DATA IN

PRE-DESIGN TETHERED WIND ENERGY SYSTEMS 


\section{S=Pl}




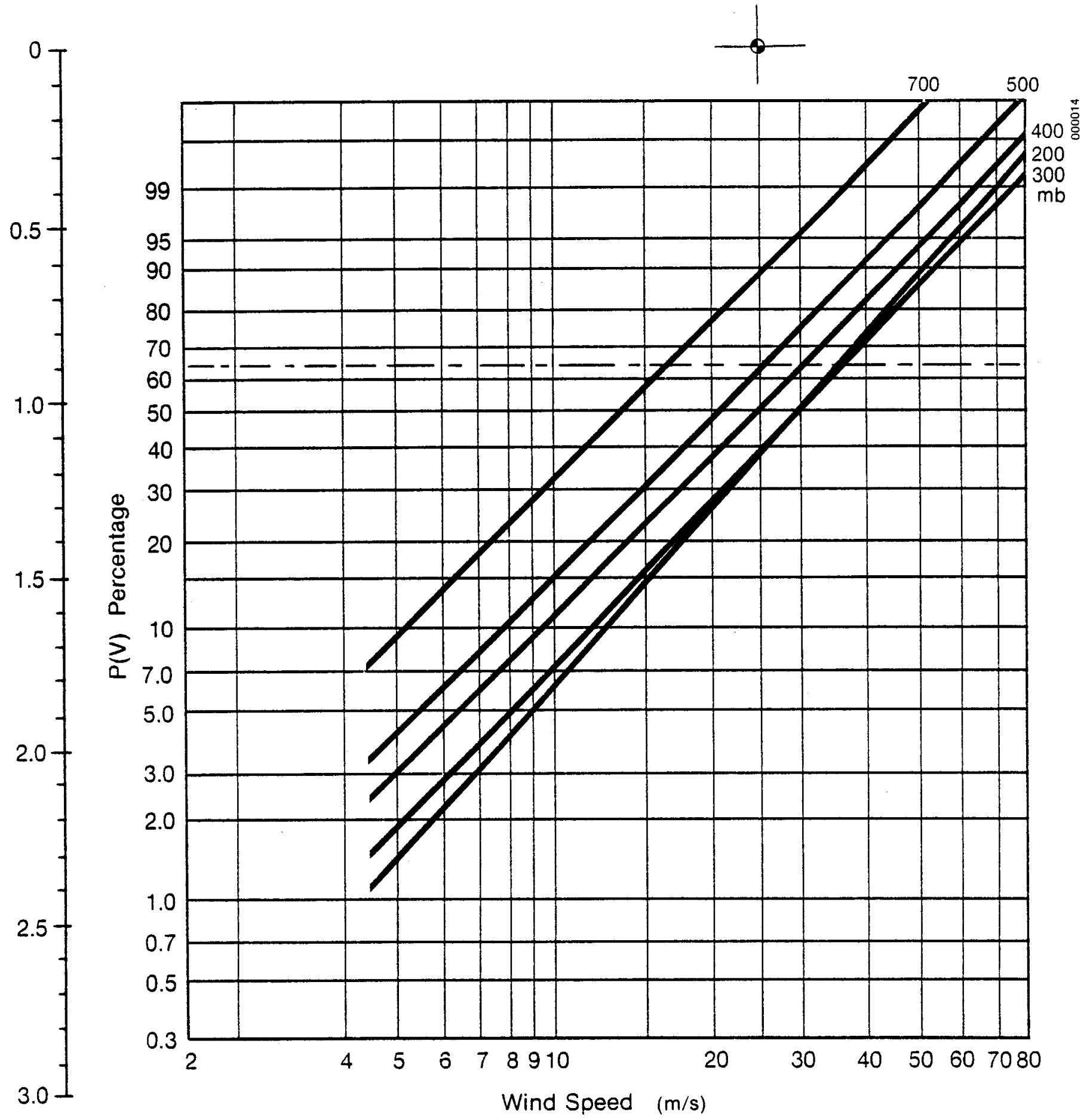

Figure B-1. Annual Probability Distribution of Velocity: Albany, NY 


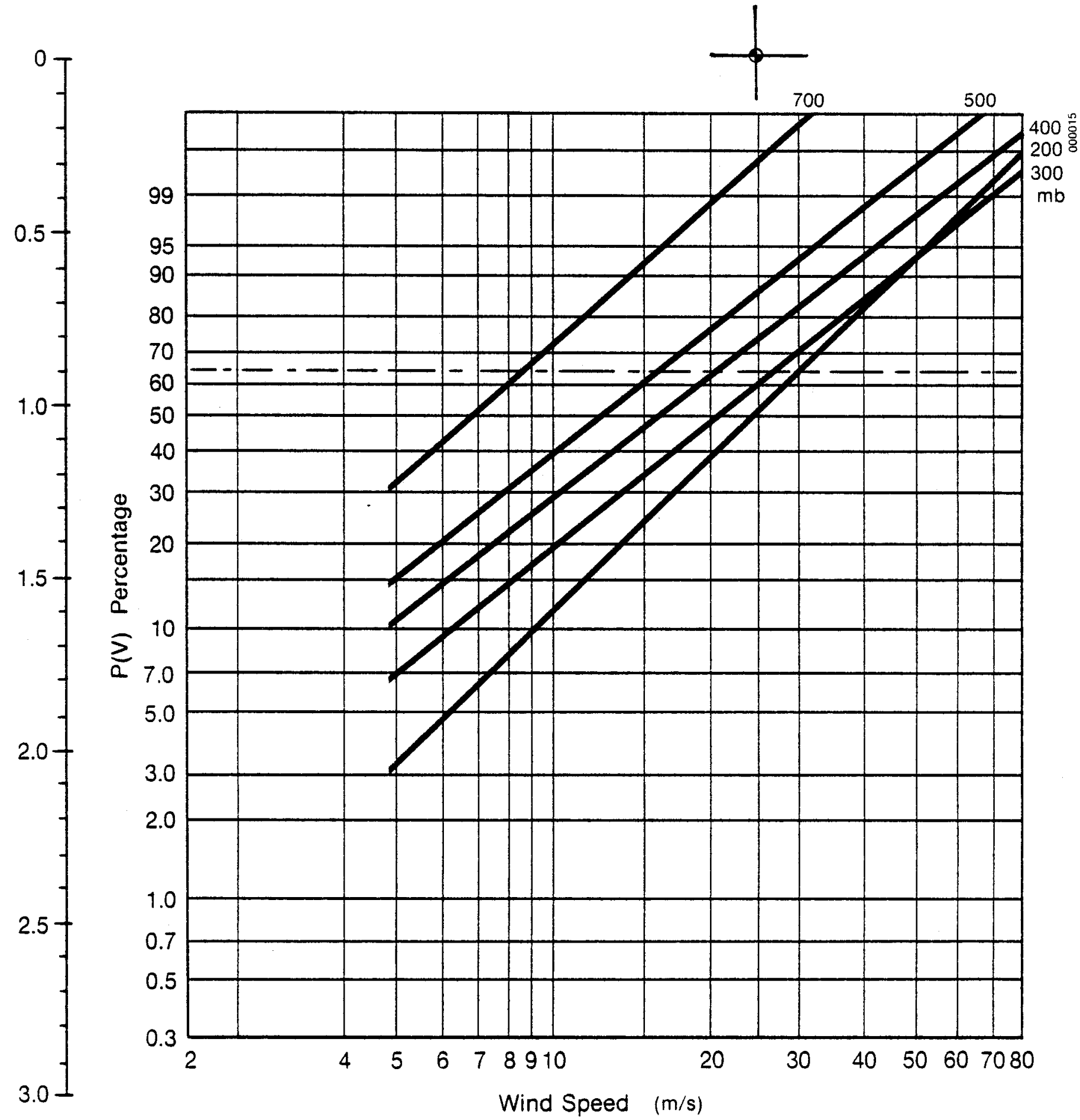

Figure B-2. Annual Probability Distribution of Velocity: Albuquerque, NM 


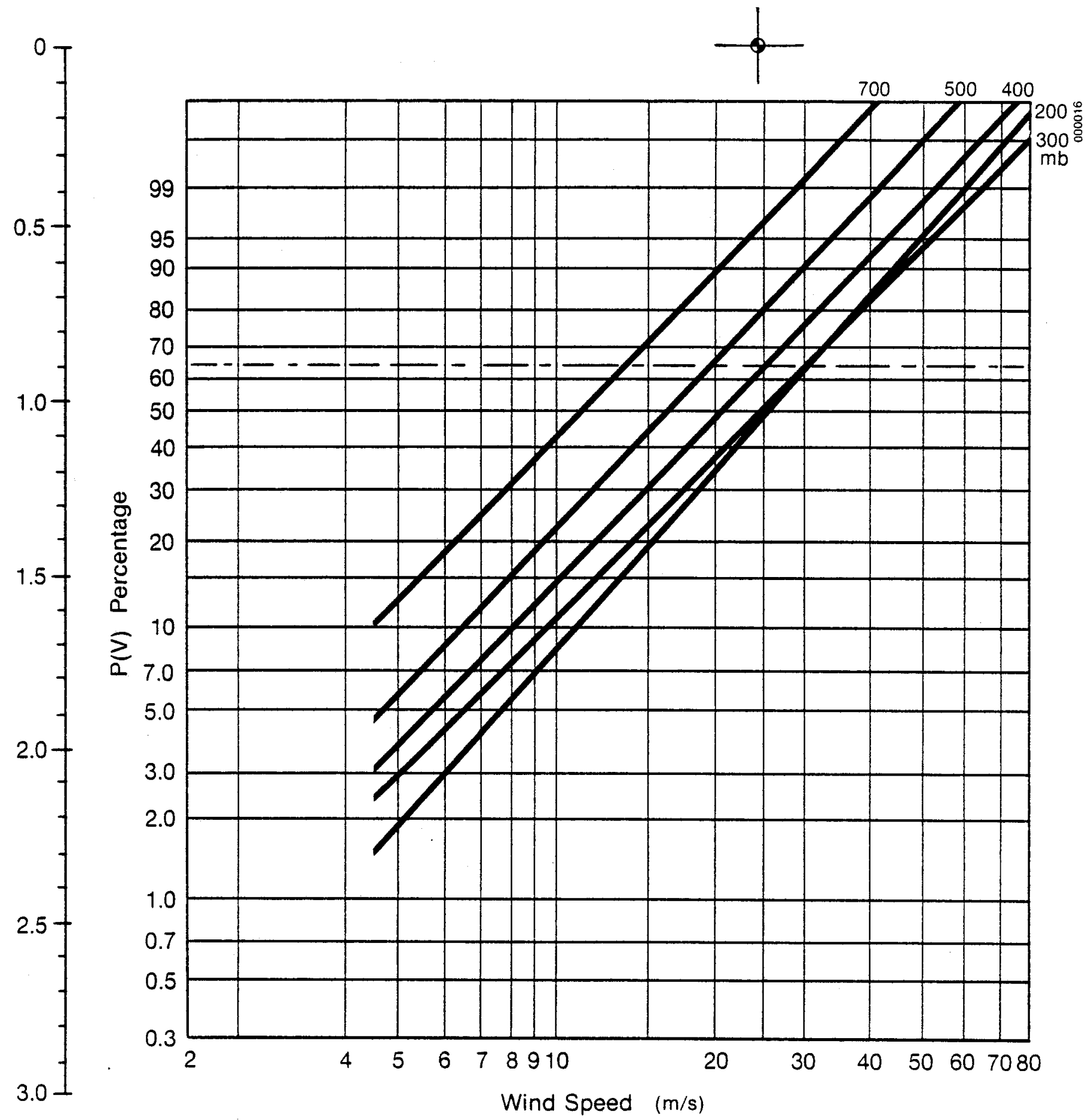

Figure B-3. Annual Probability Distribution of Velocity: Bismarck, ND 


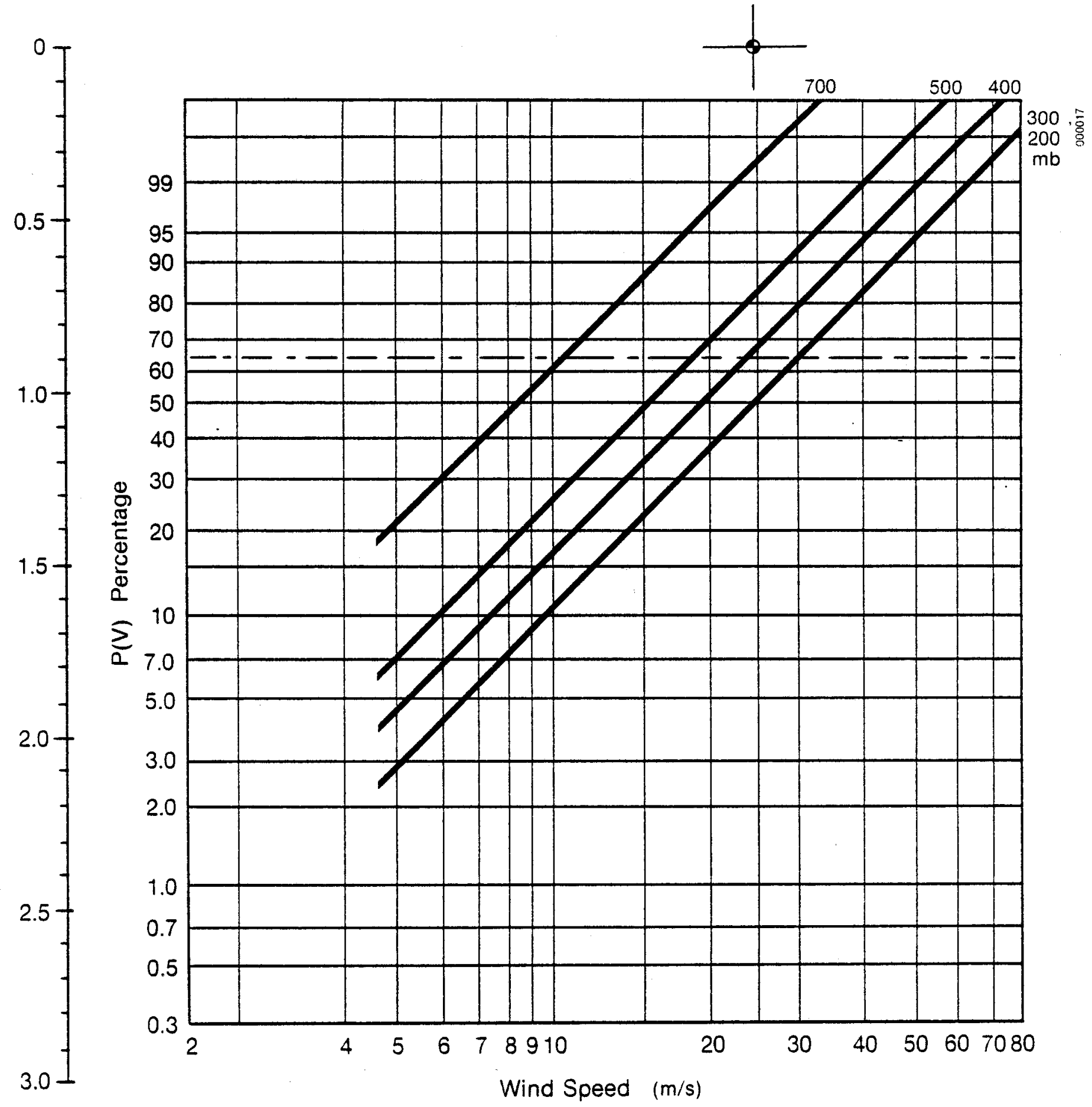

Figure B-4. Annual Probability Distribution of Velocity: Boise, ID 


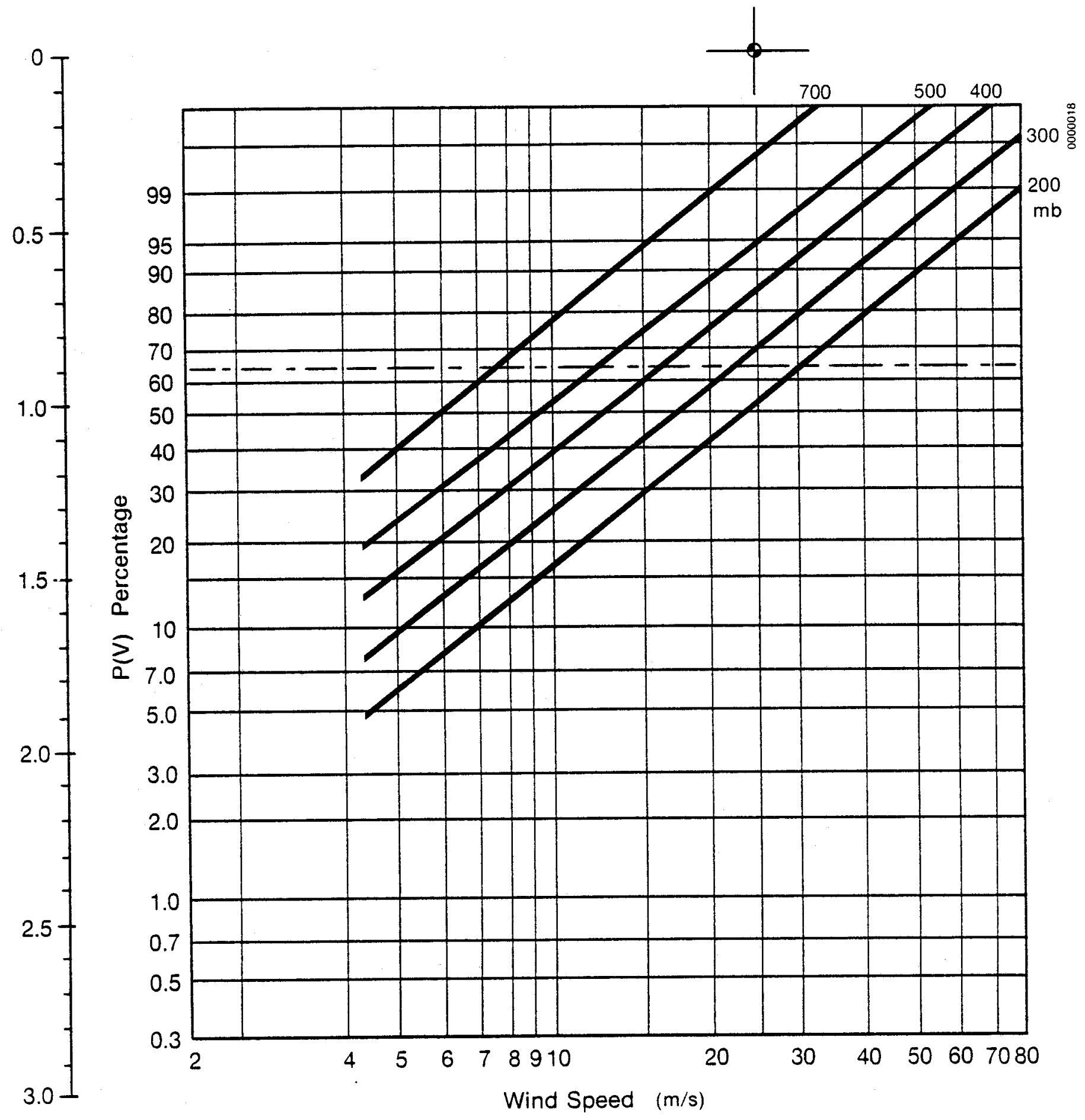

Figure B-5. Annual Probability Distribution of Velocity: Brownsville, TX 


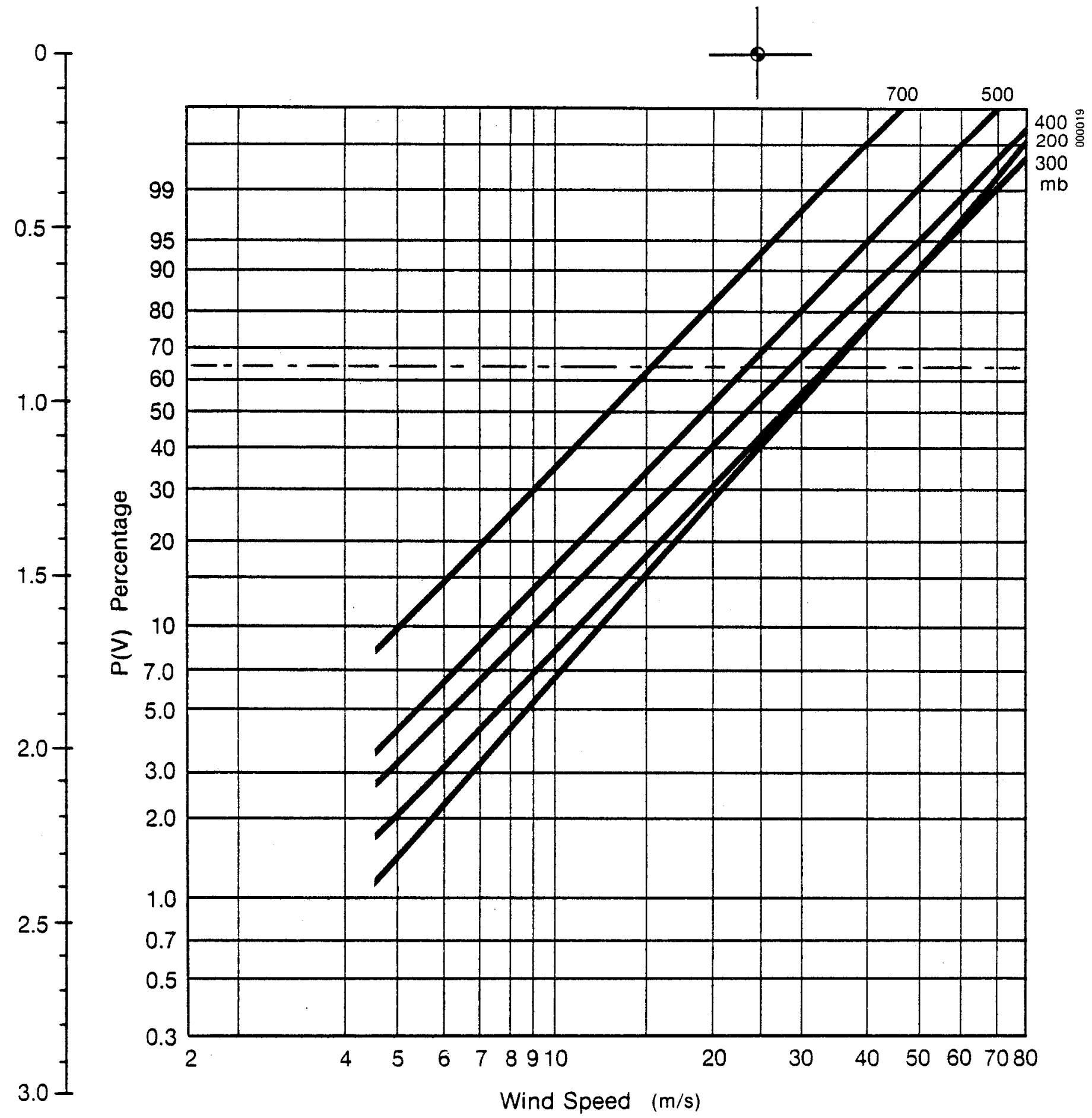

Figure B-6. Annual Probability Distribution of Velocity: Buffalo, NY 


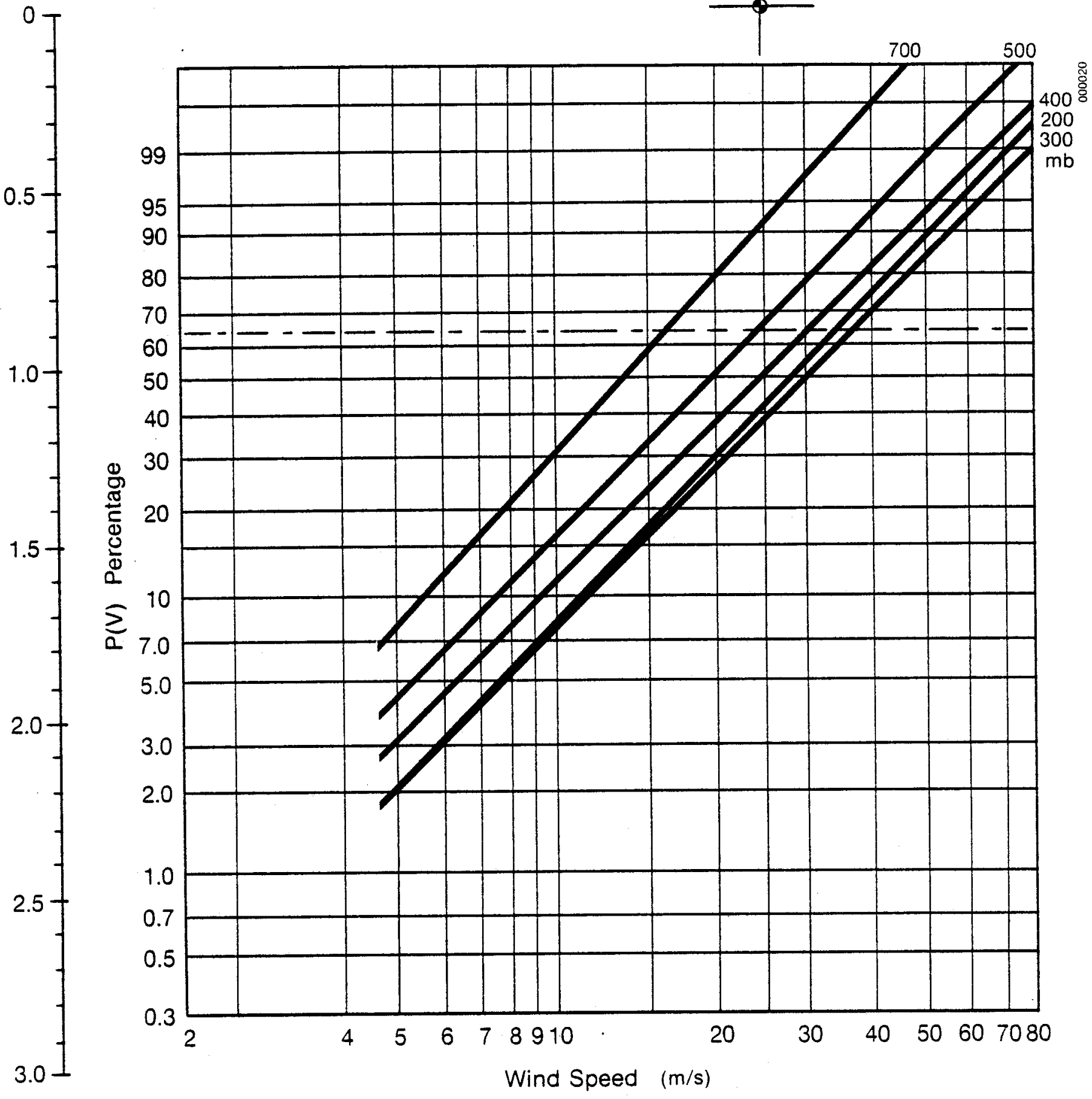

Figure B-7. Annual Probability Distribution of Velocity: Caribou, ME 


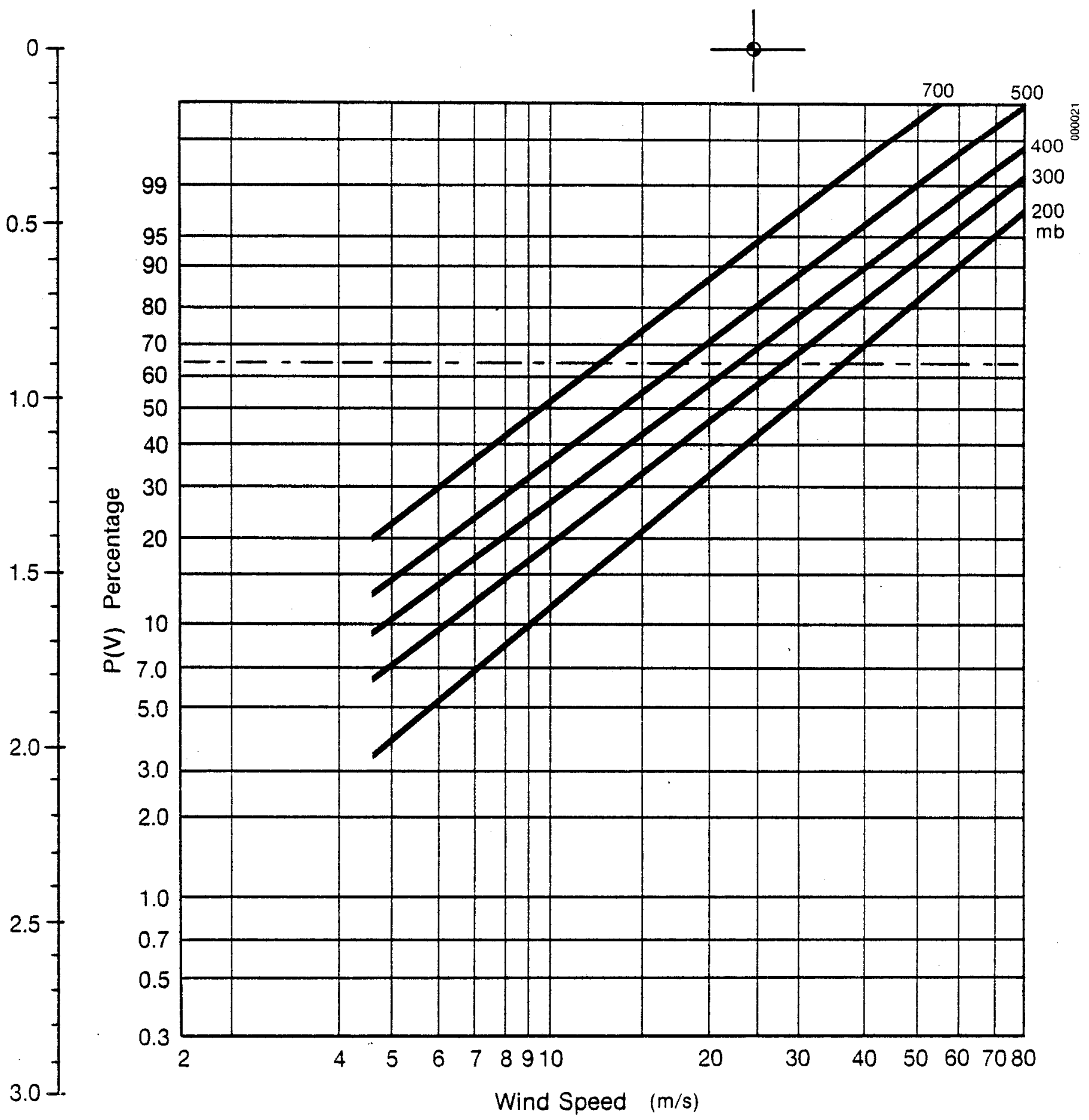

Figure B-8. Annual Probability Distribution of Velocity: Charleston, SC 


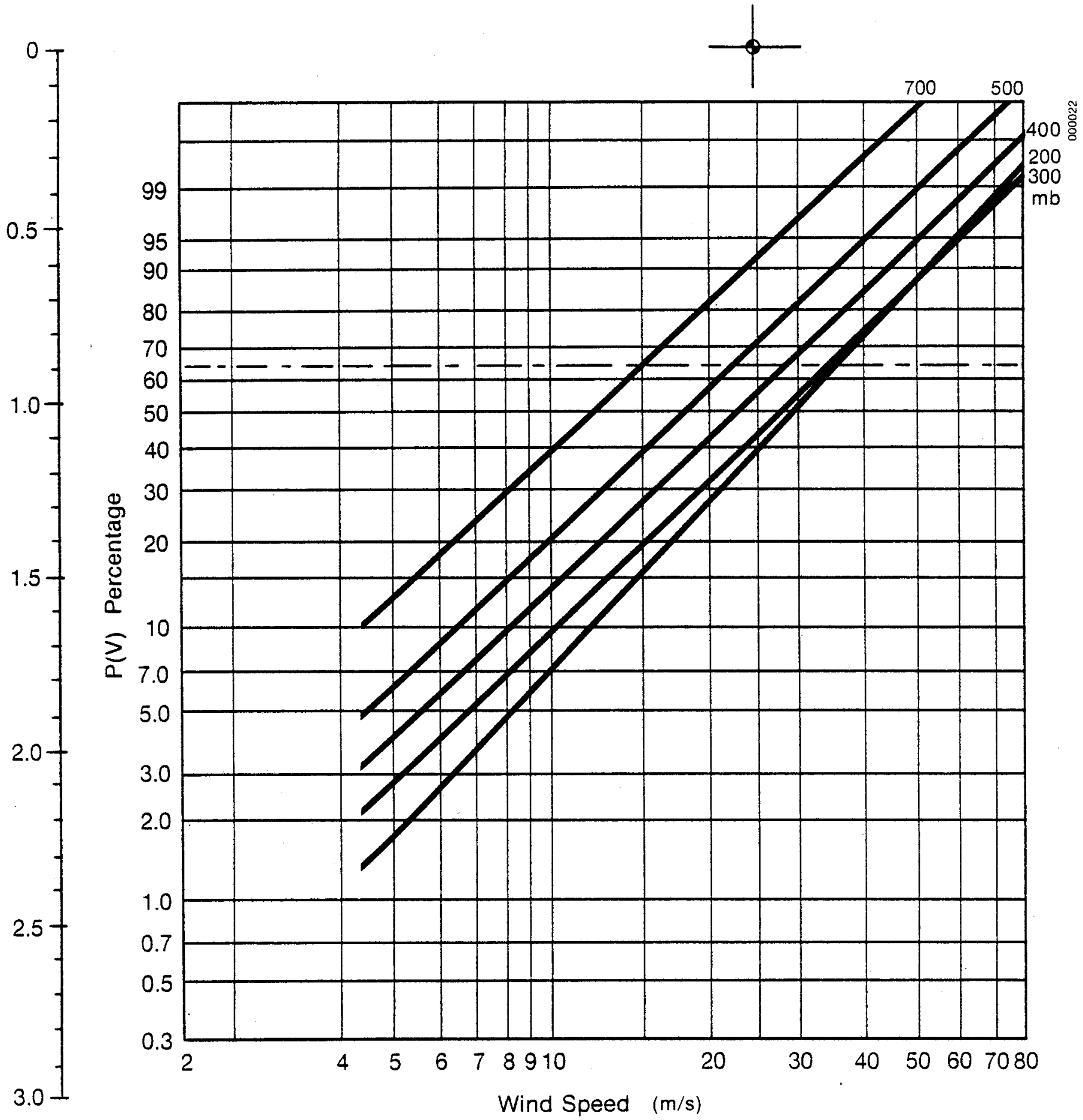

Figure B-9. Annual Probability Distribution of Velocity: Dayton, OH 


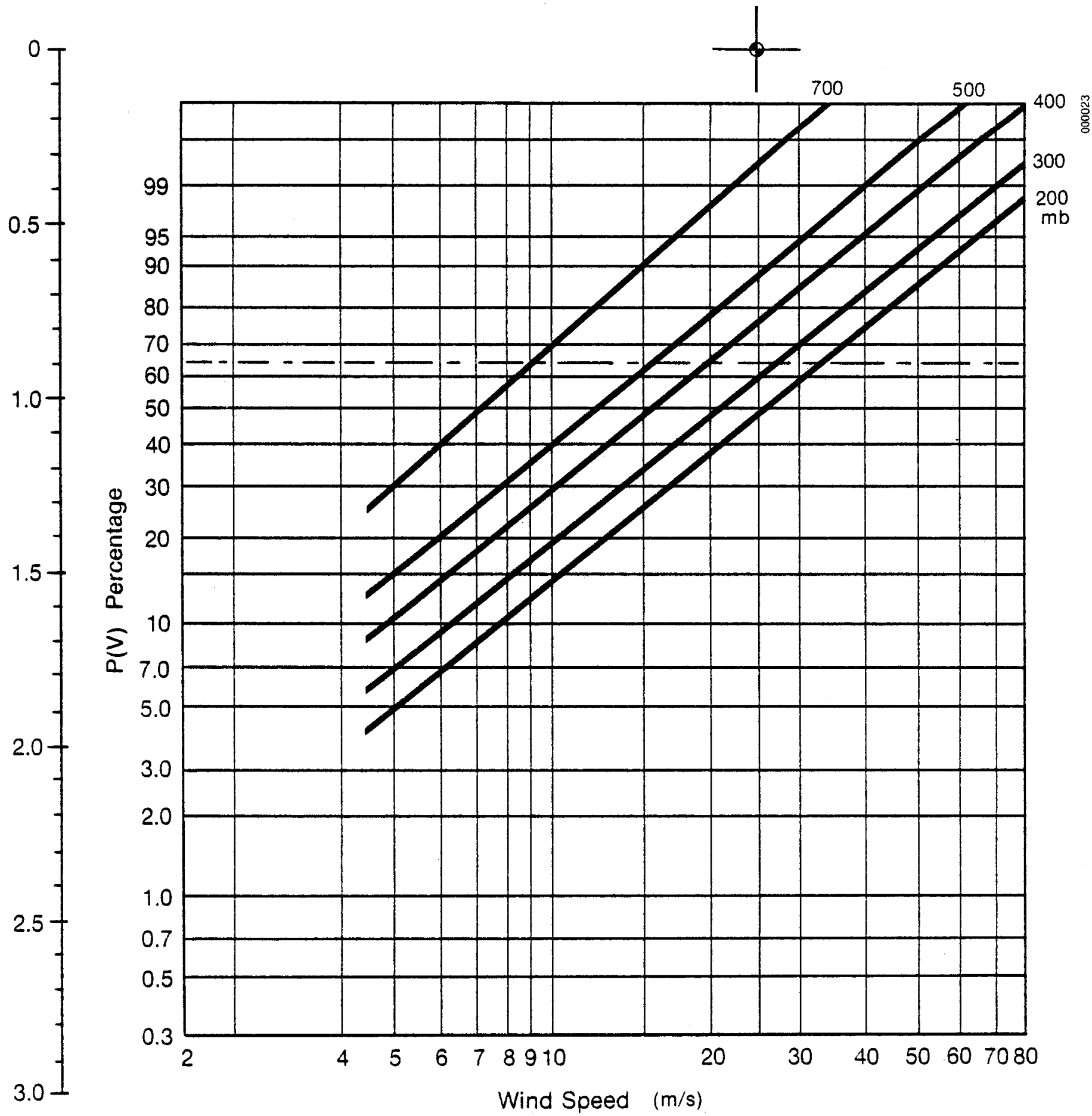

Figure B-10. Annual Probability Distribution of Velocity: Del Rio, TX 


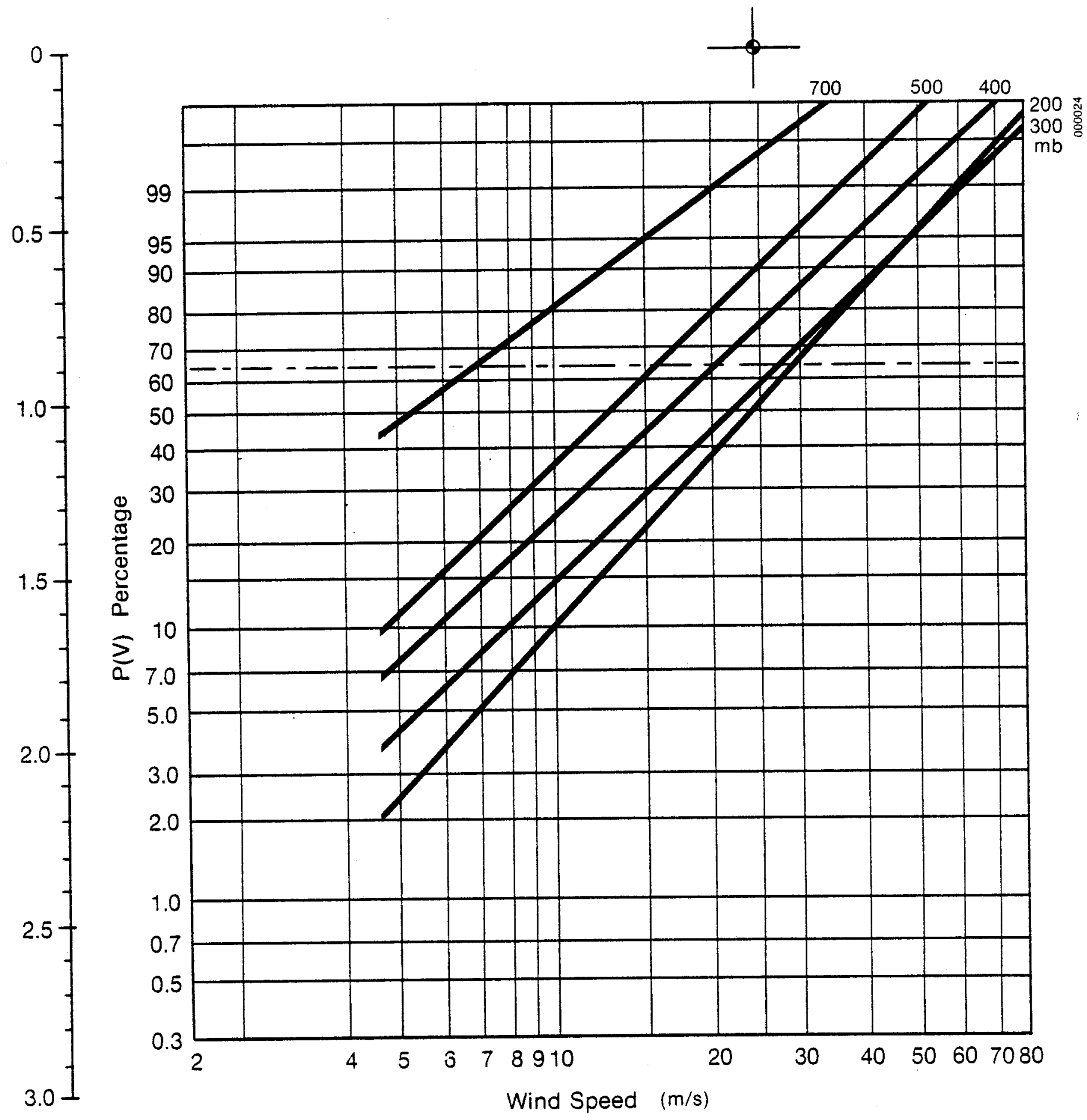

Figure B-11. Annual Probability Distribution of Velocity: Denver, CO 


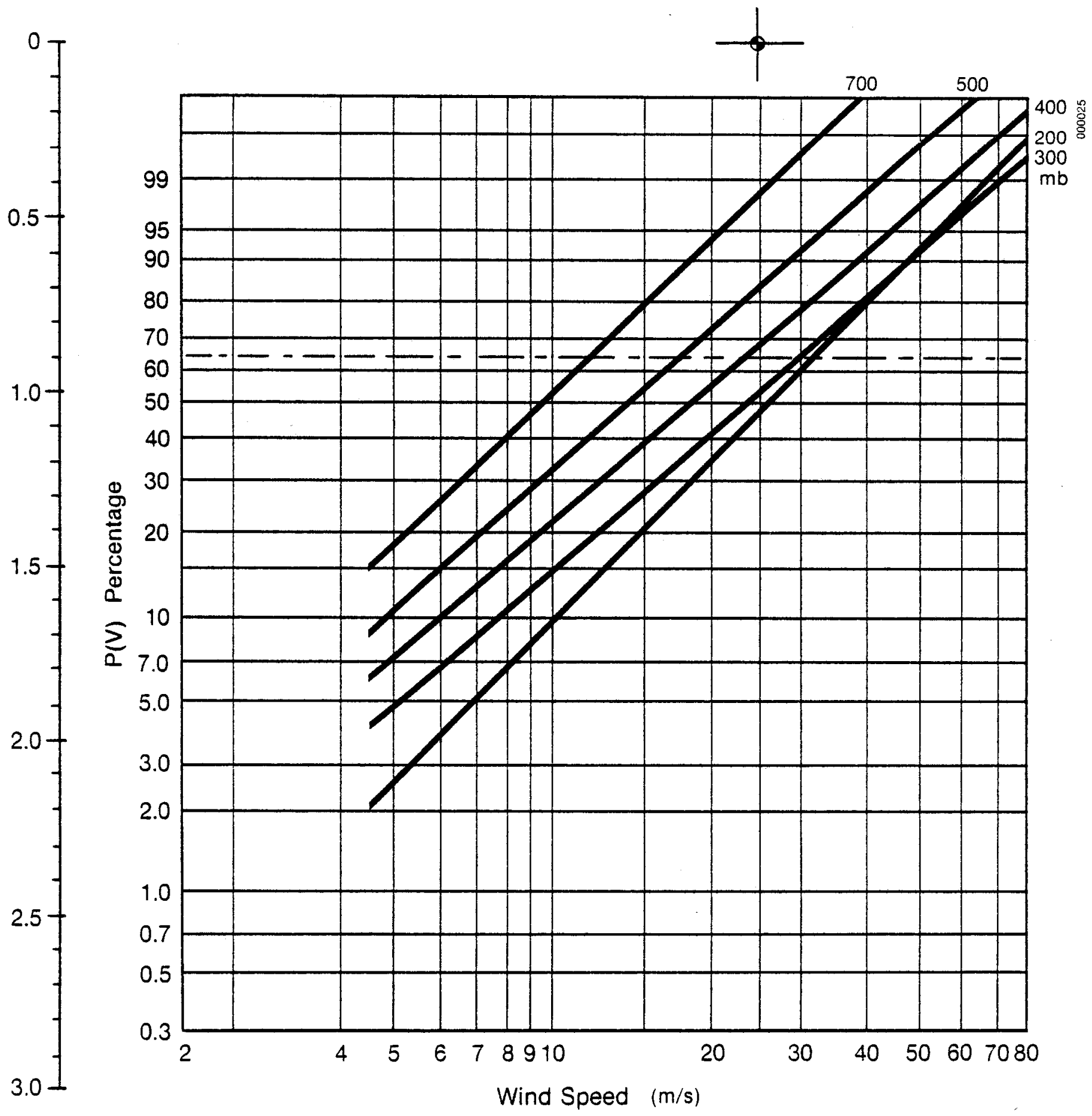

Figure B-12. Annual Probability Distribution of Velocity: Dodge City, KS 


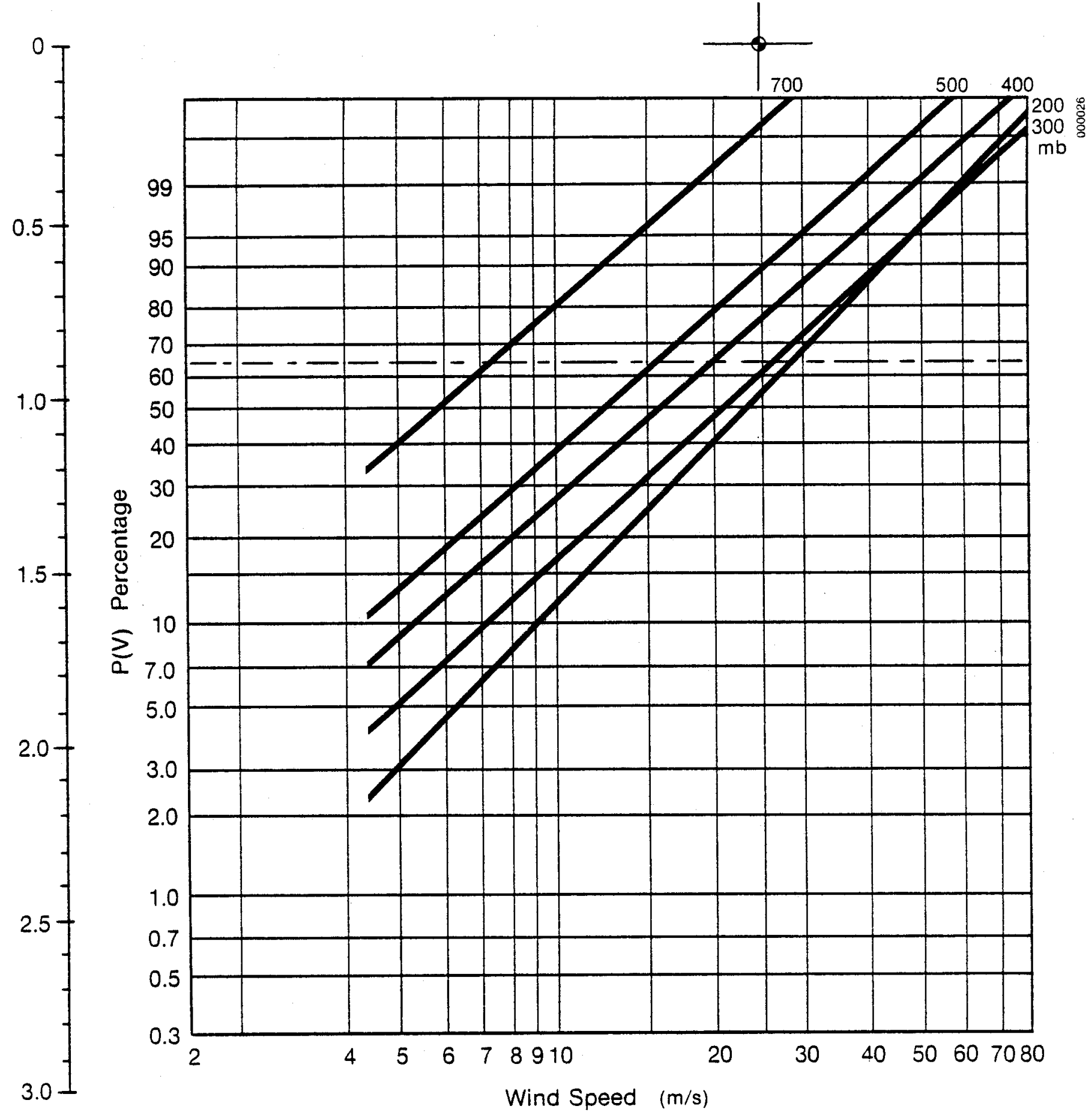

Figure B-13. Annual Probability Distribution of Velocity: Ely, NV 


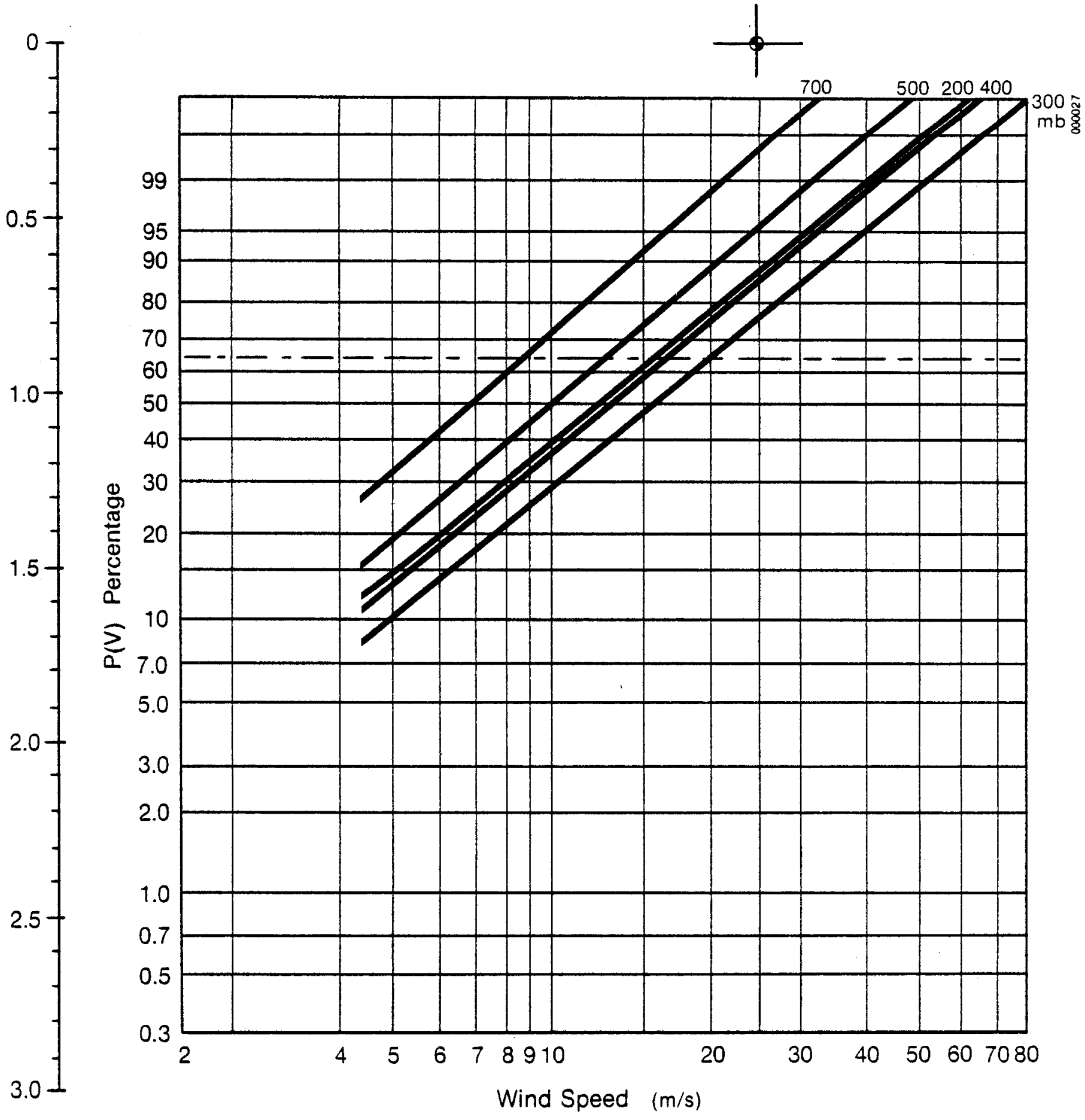

Figure B-14. Annual Probability Distribution of Velocity: Fairbanks, AK 


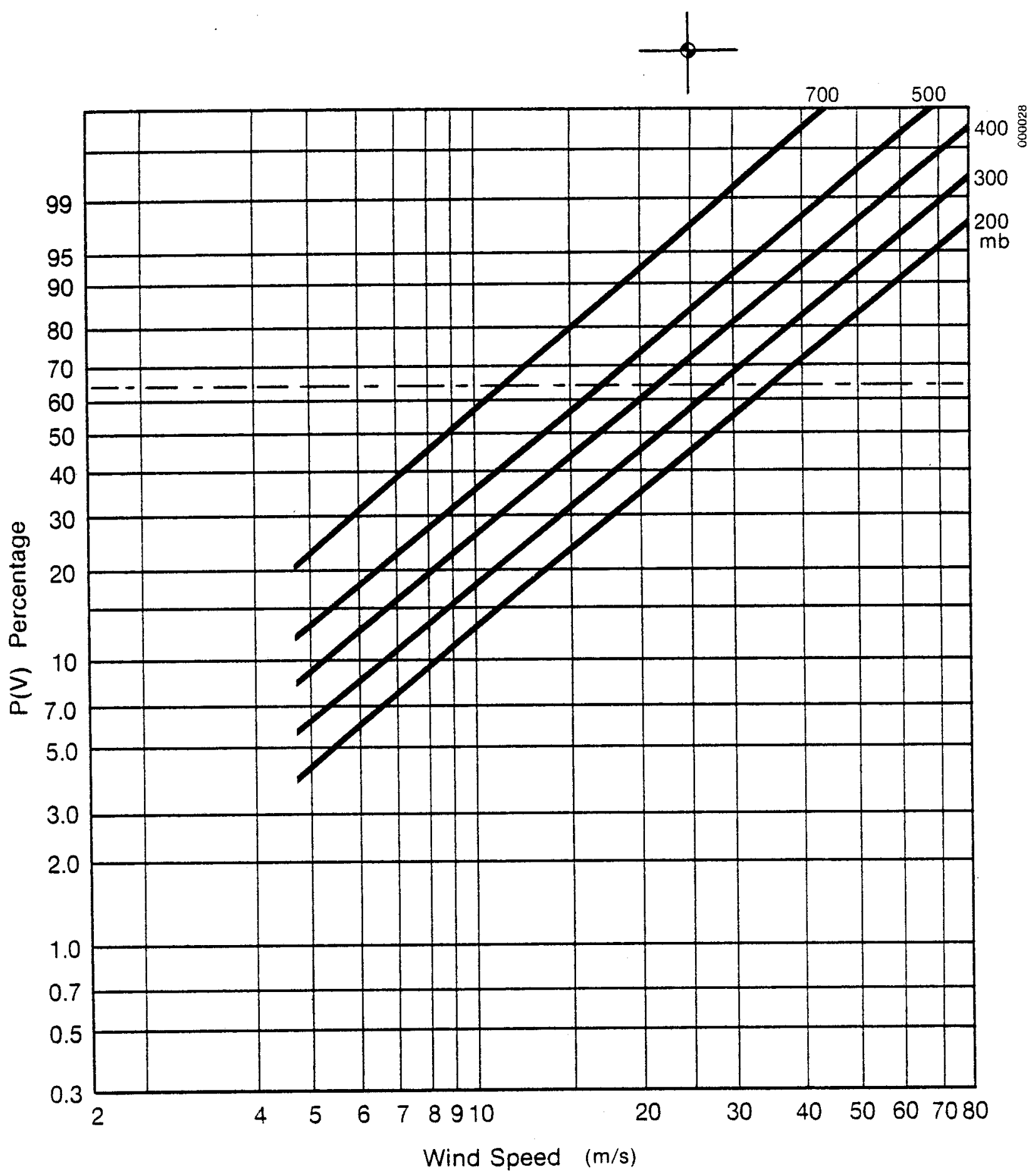

Figure B-15. Annual Probability Distribution of Velocity: Ft. Worth, TX 


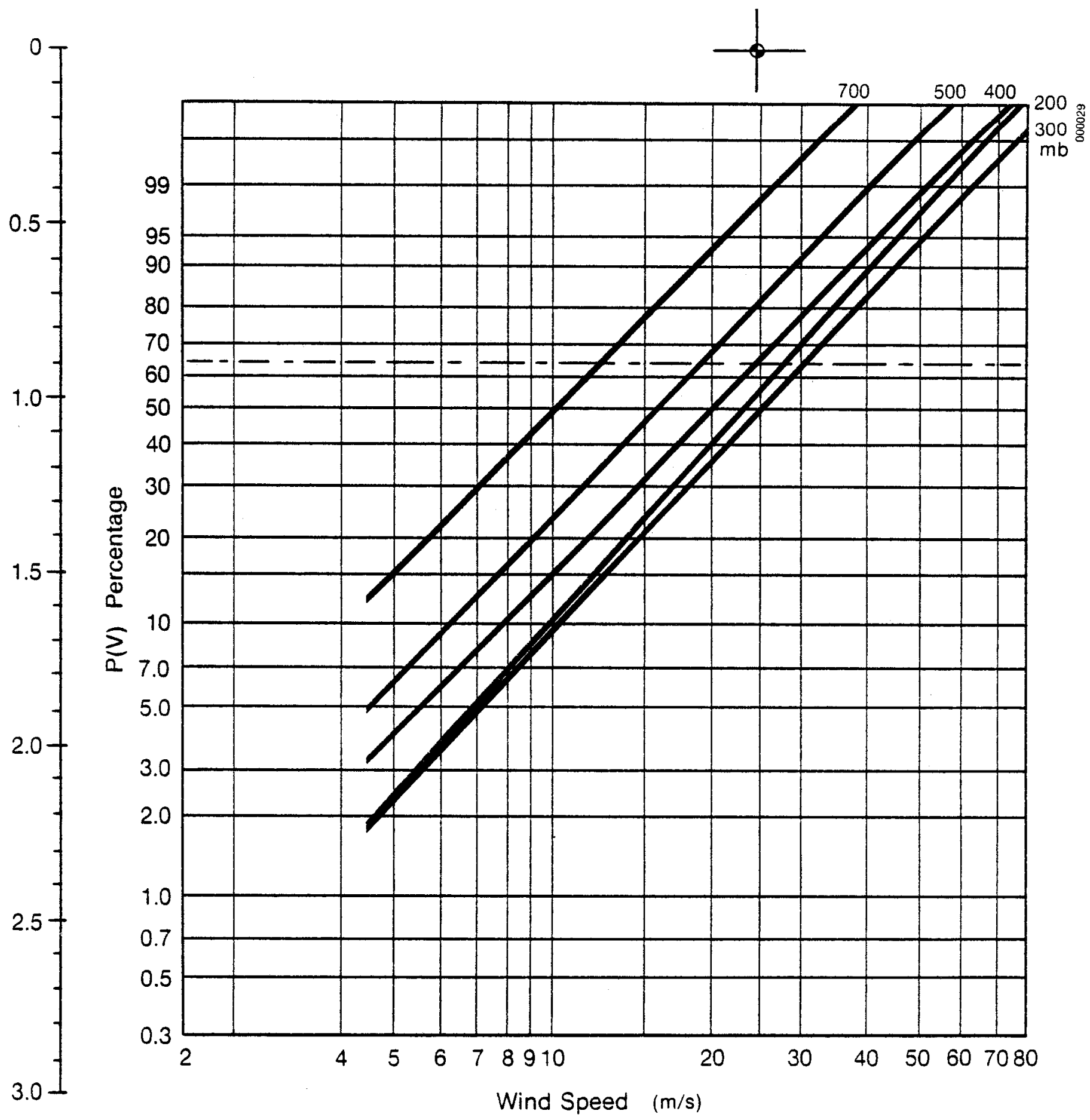

Figure B-16. Annual Probability Distribution of Velocity: Glasgow, ME 


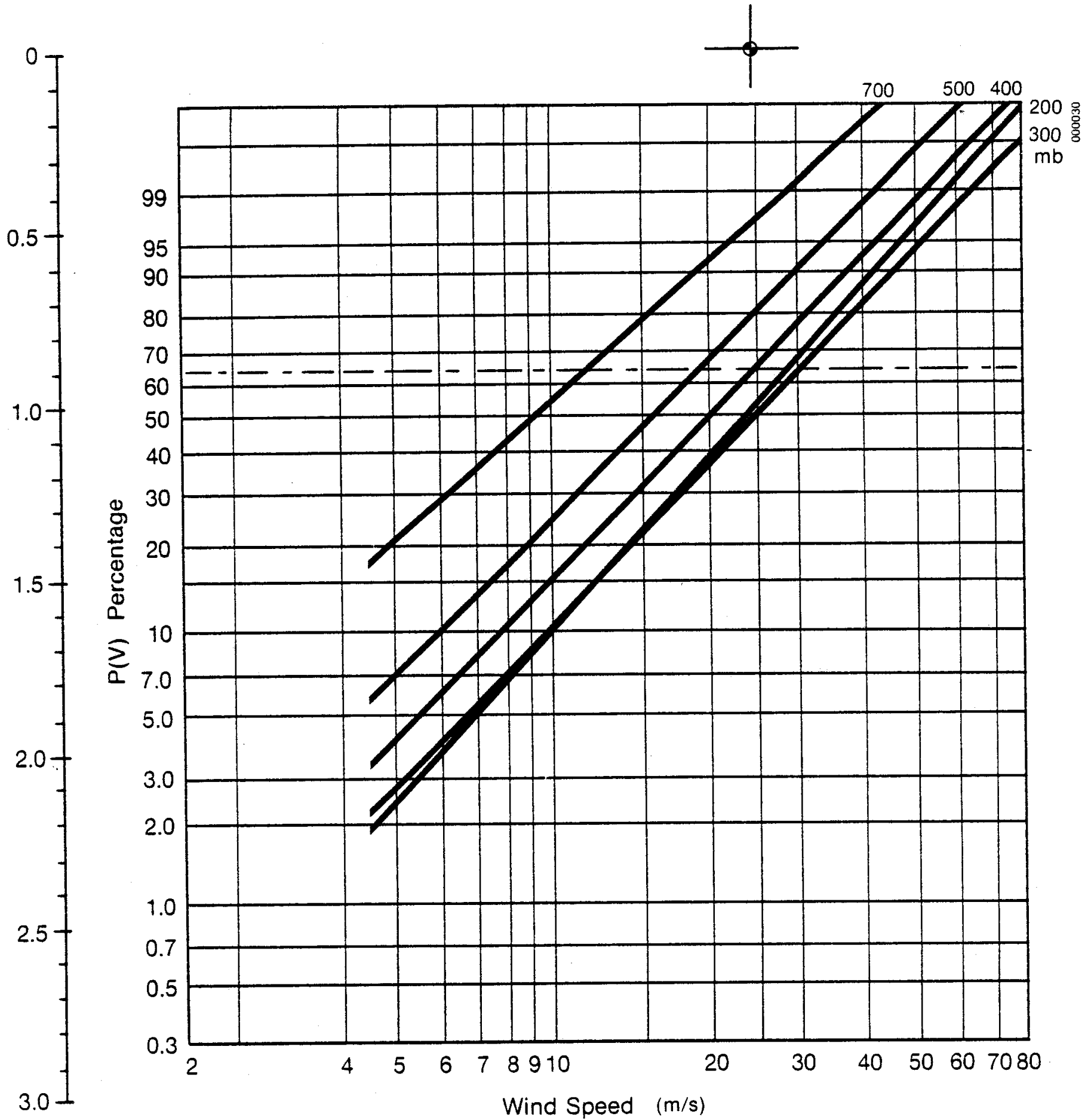

Figure B-17. Annual Probability Distribution of Velocity: Great Falls, MT 


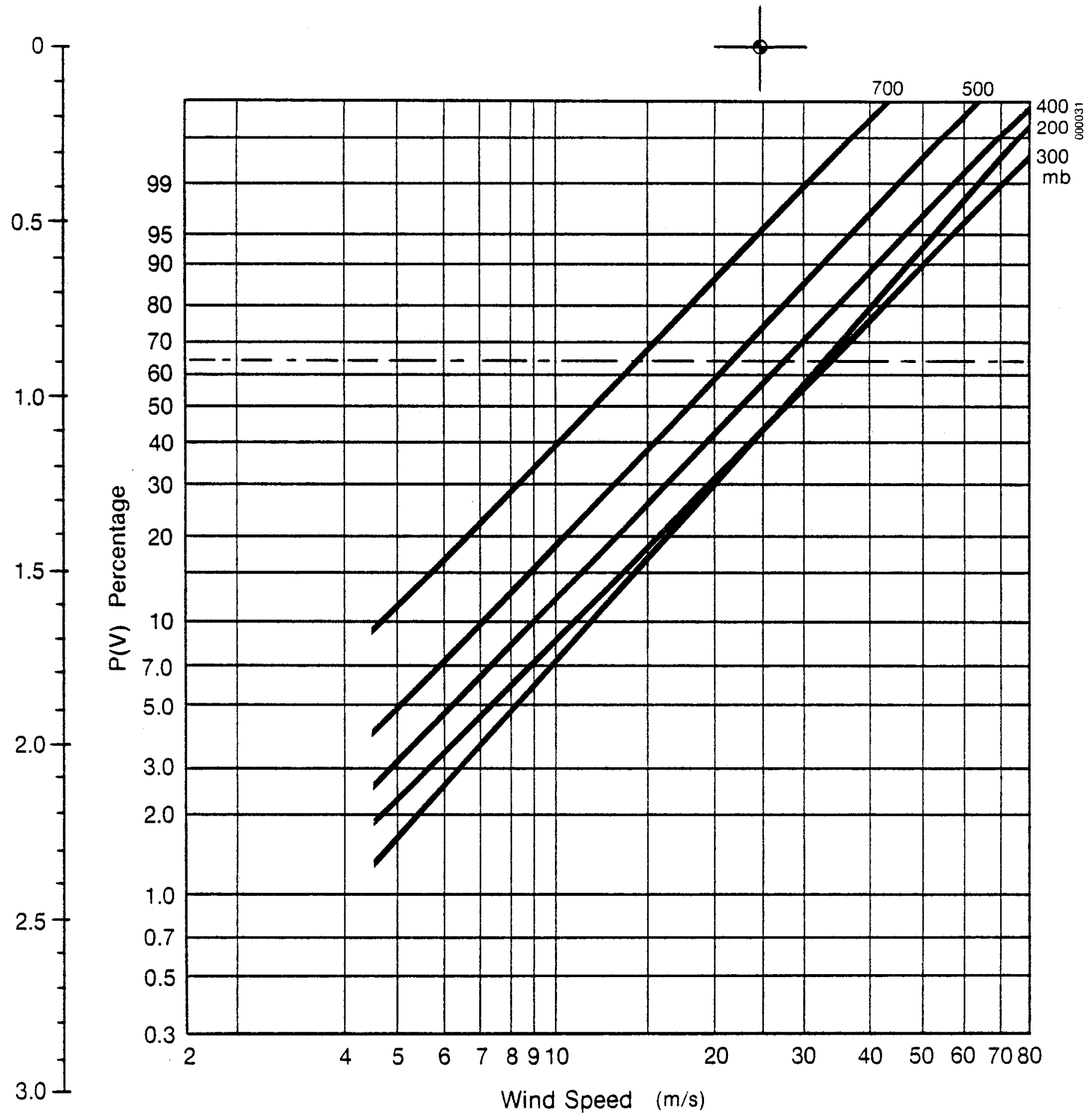

Figure B-18. Annual Probability Distribution of Velocity: Green Bay, WI 


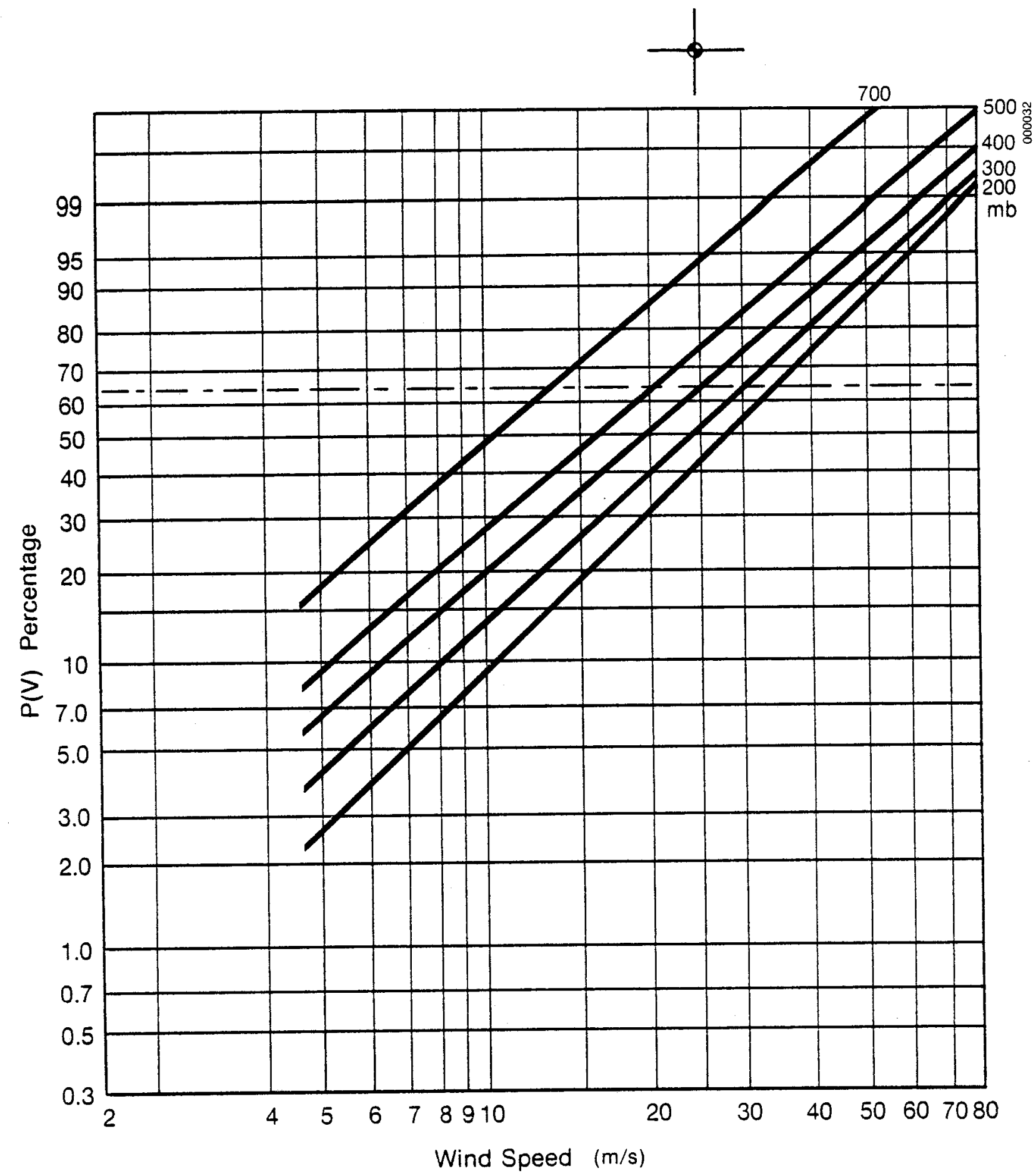

Figure B-19. Annual Probability Distribution of Velocity: Greensboro, NC 


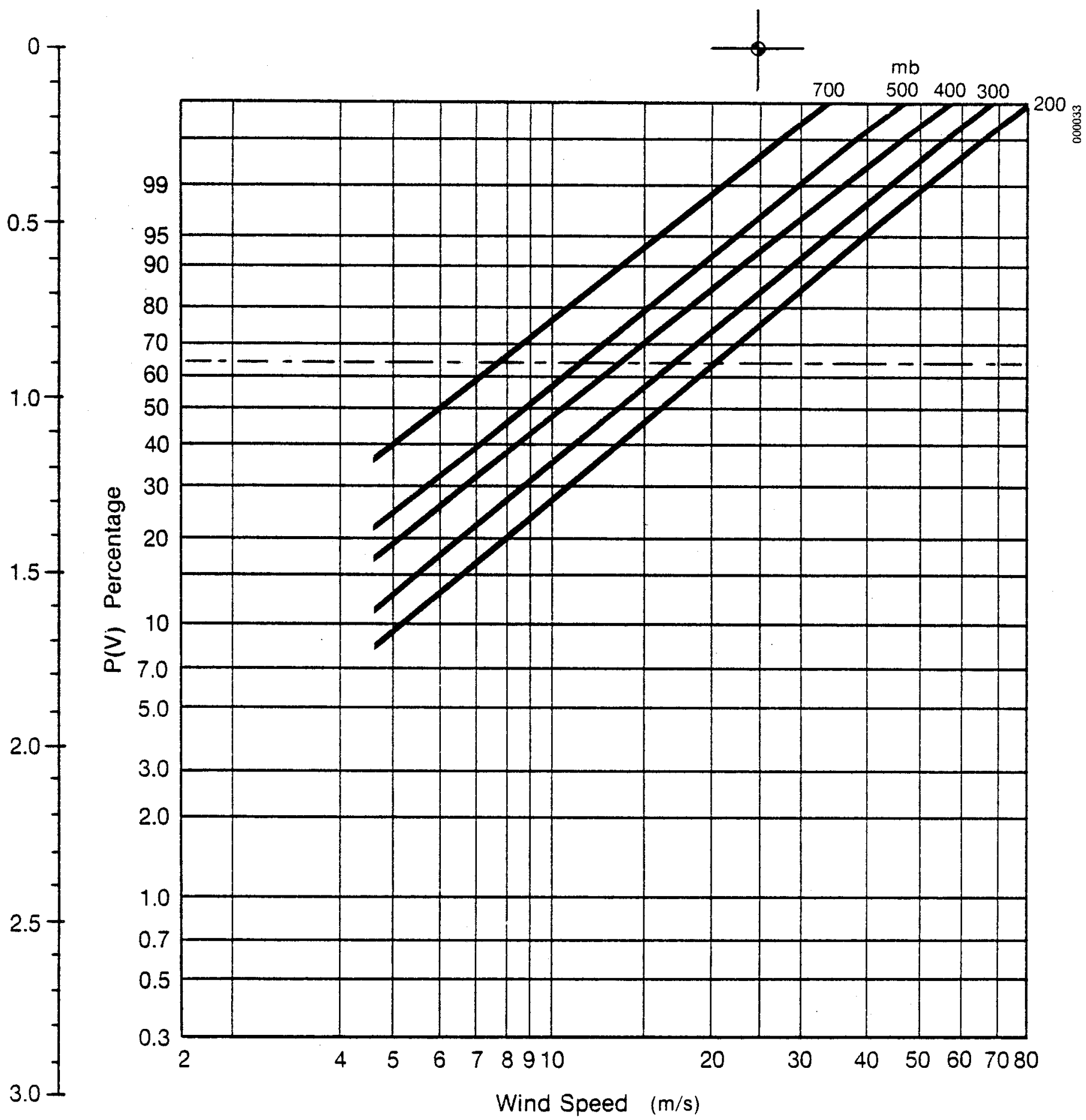

Figure B-20. Annual Probability Distribution of Velocity: Guadalupe Island, Mexico 


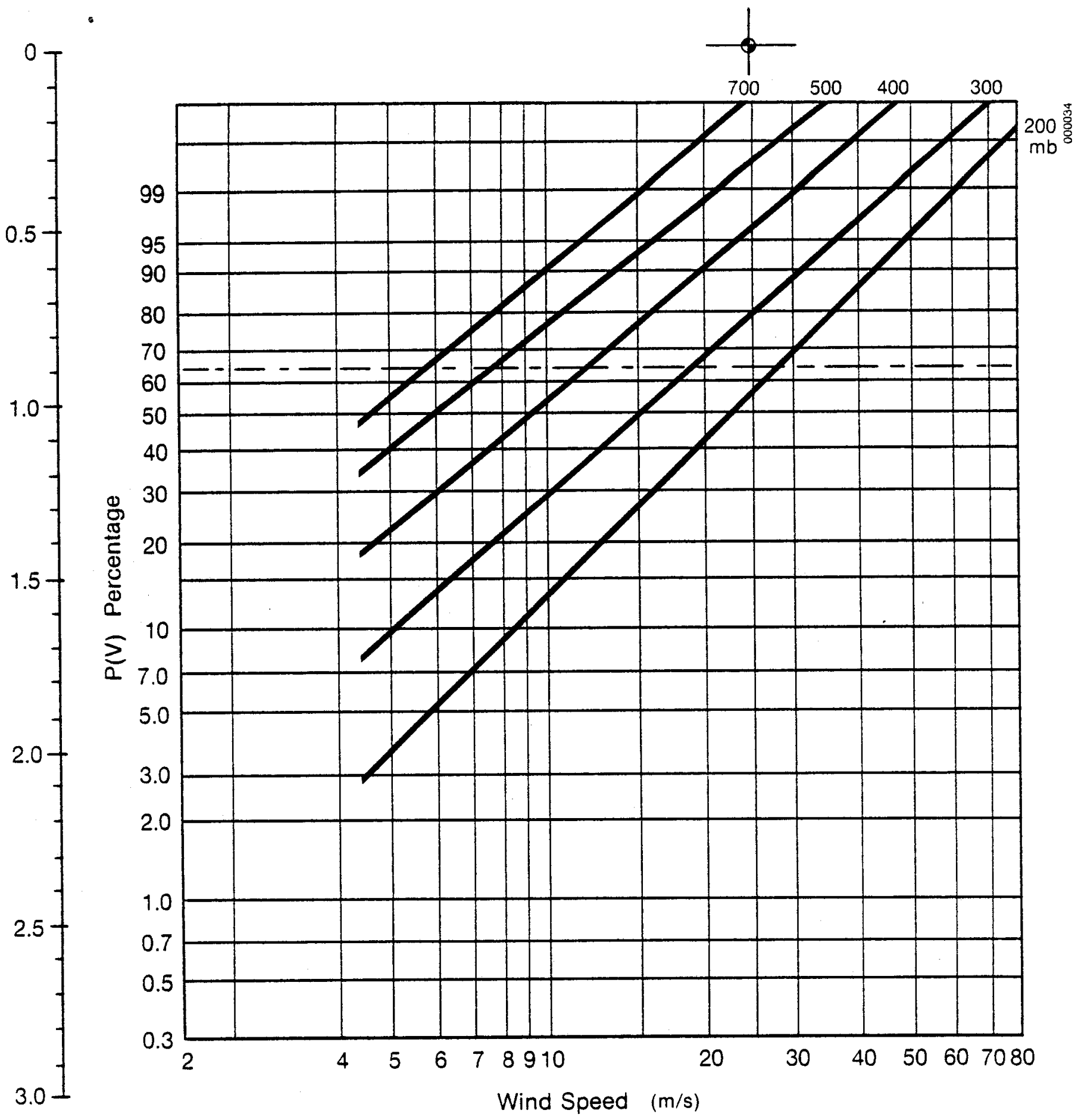

Figure B-21. Annual Probability Distribution of Velocity: Hilo, HI 


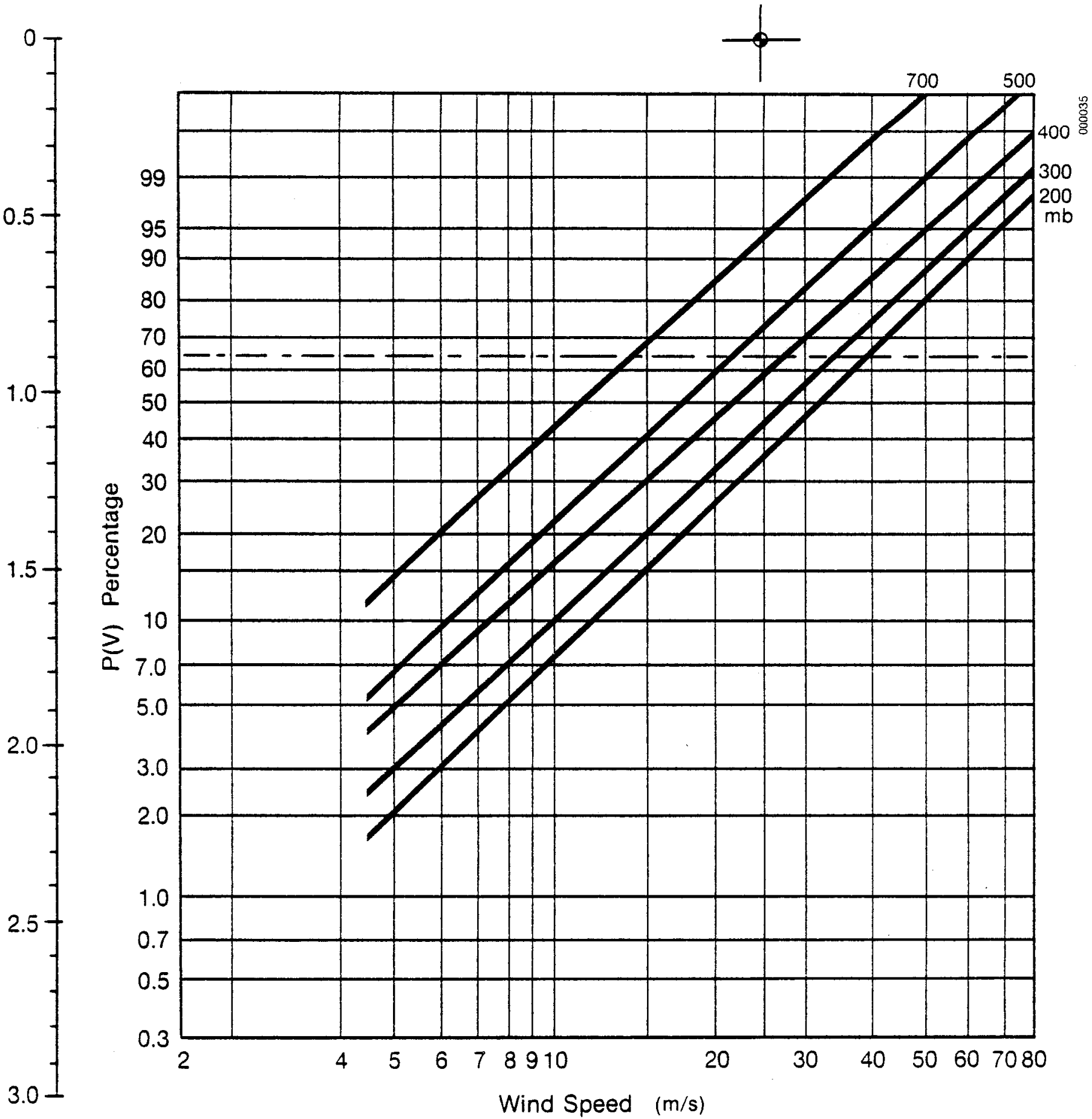

Figure B-22. Annual Probability Distribution of Velocity: Huntington, WV 


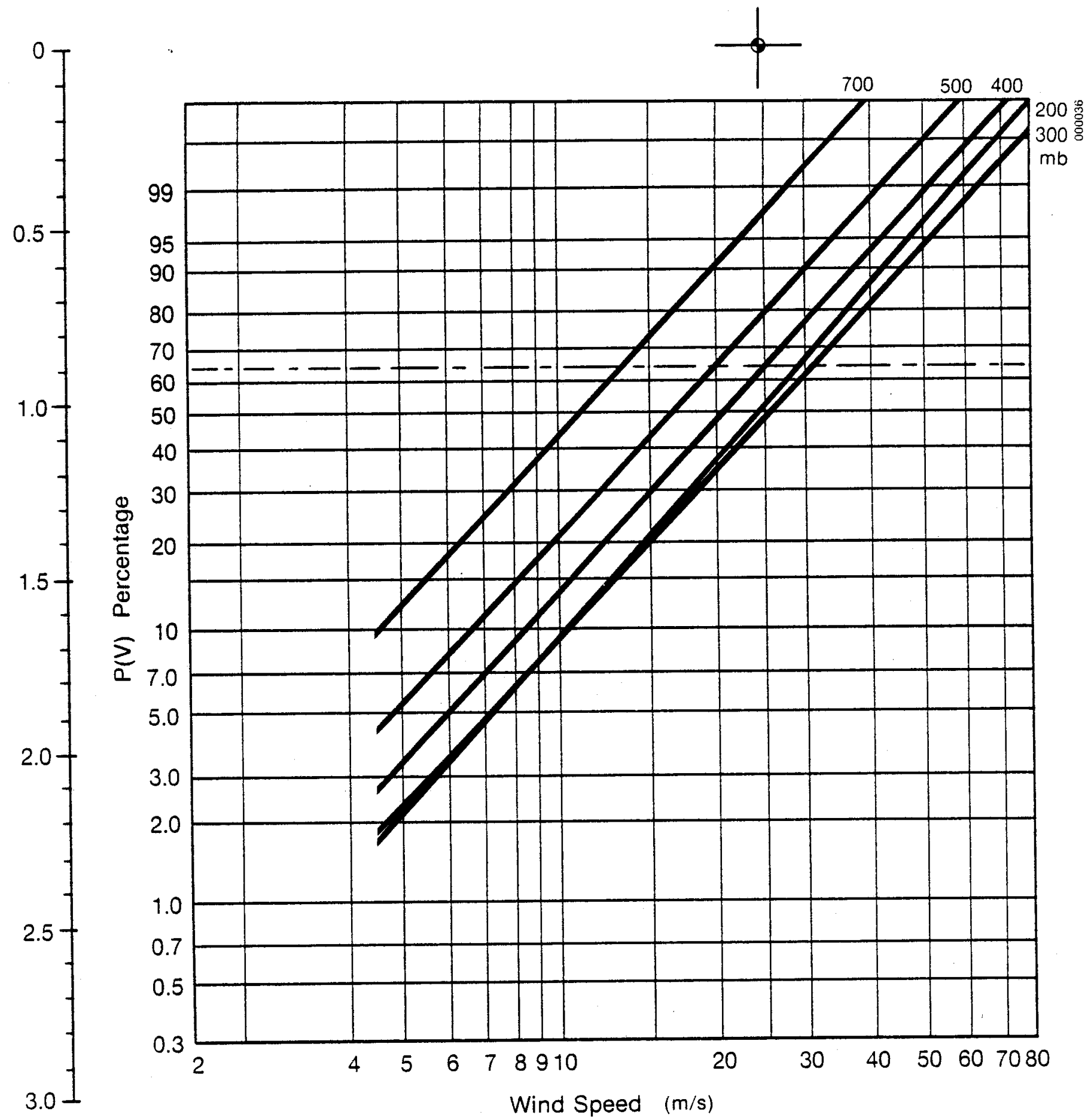

Figure B-23. Annual Probability Distribution of Velocity: International Falls, MN 


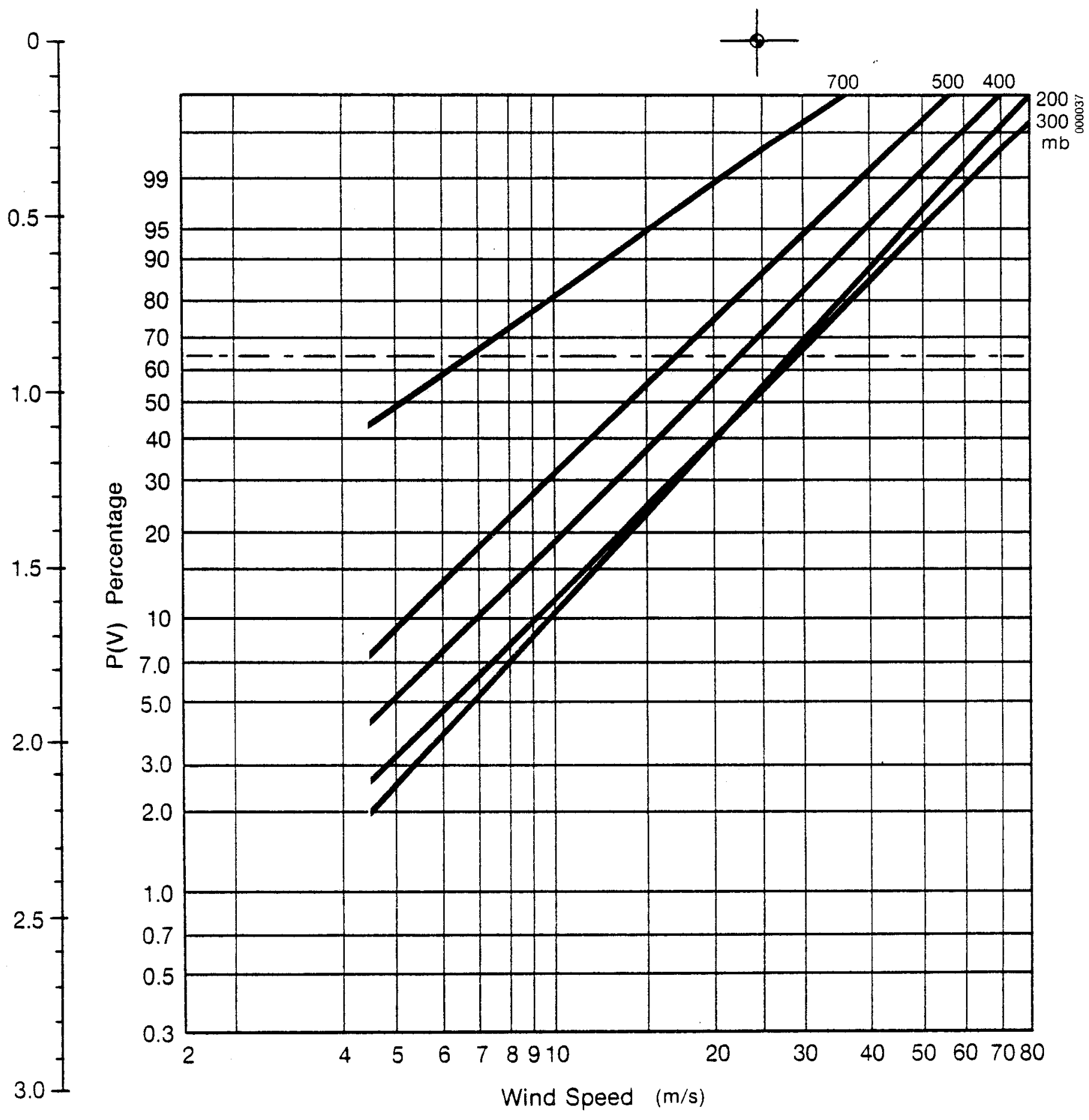

Figure B-24. Annual Probability Distribution of Velocity: Lander, WY 


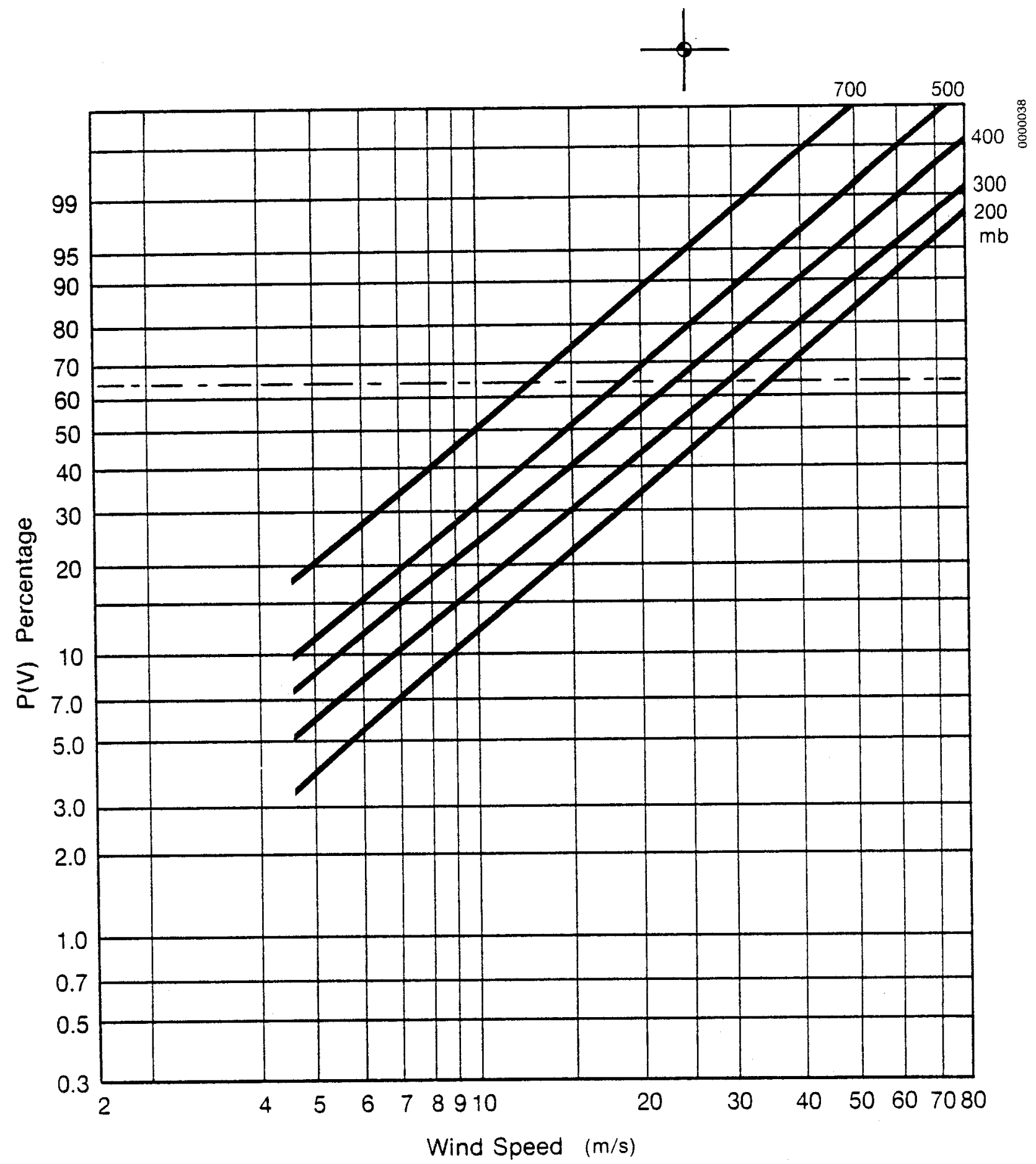

Figure B-25. Annual Probability Distribution of Velocity: Little Rock, AR 


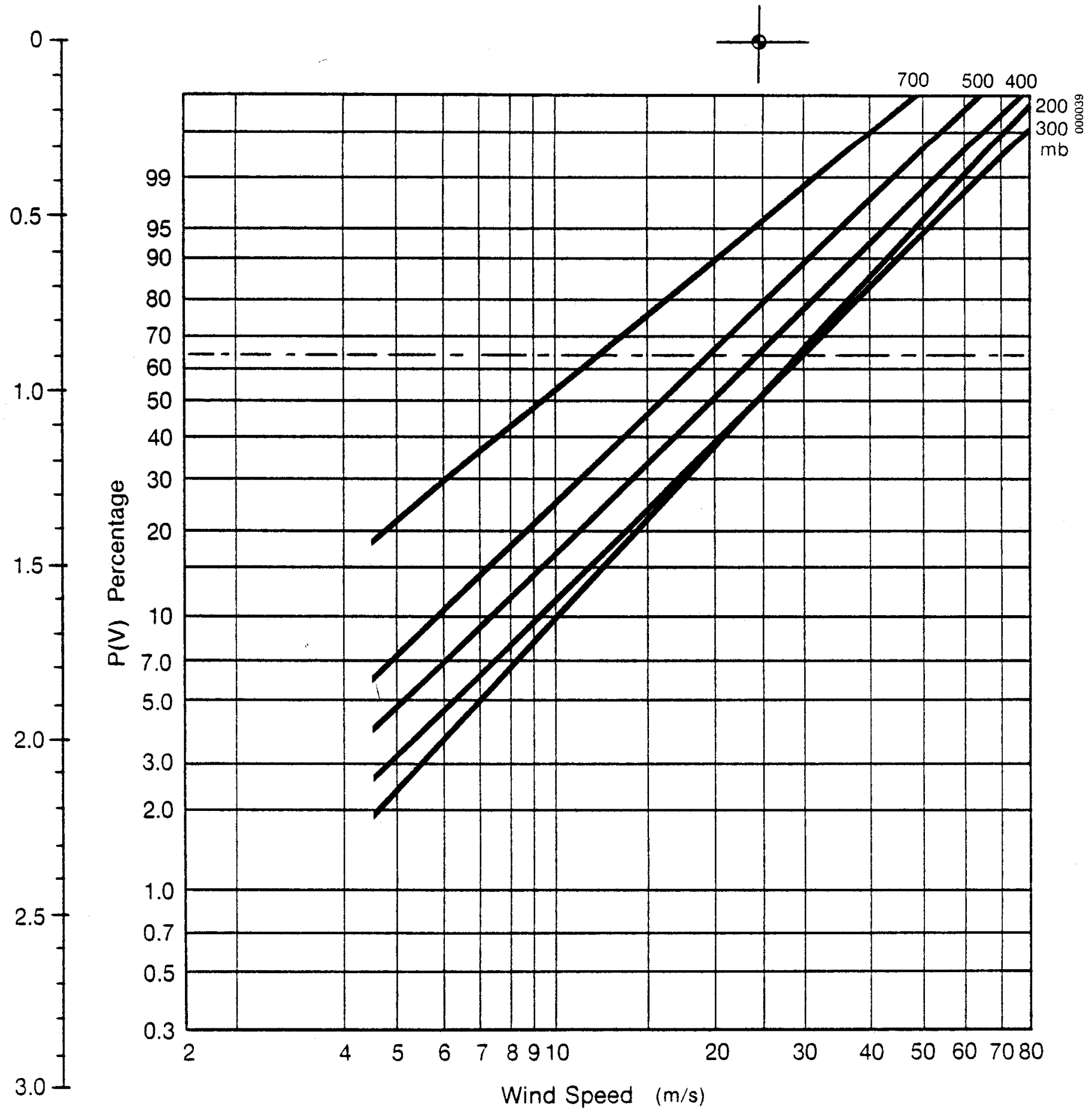

Figure B-26. Annual Probability Distribution of Velocity: Medford, OR 


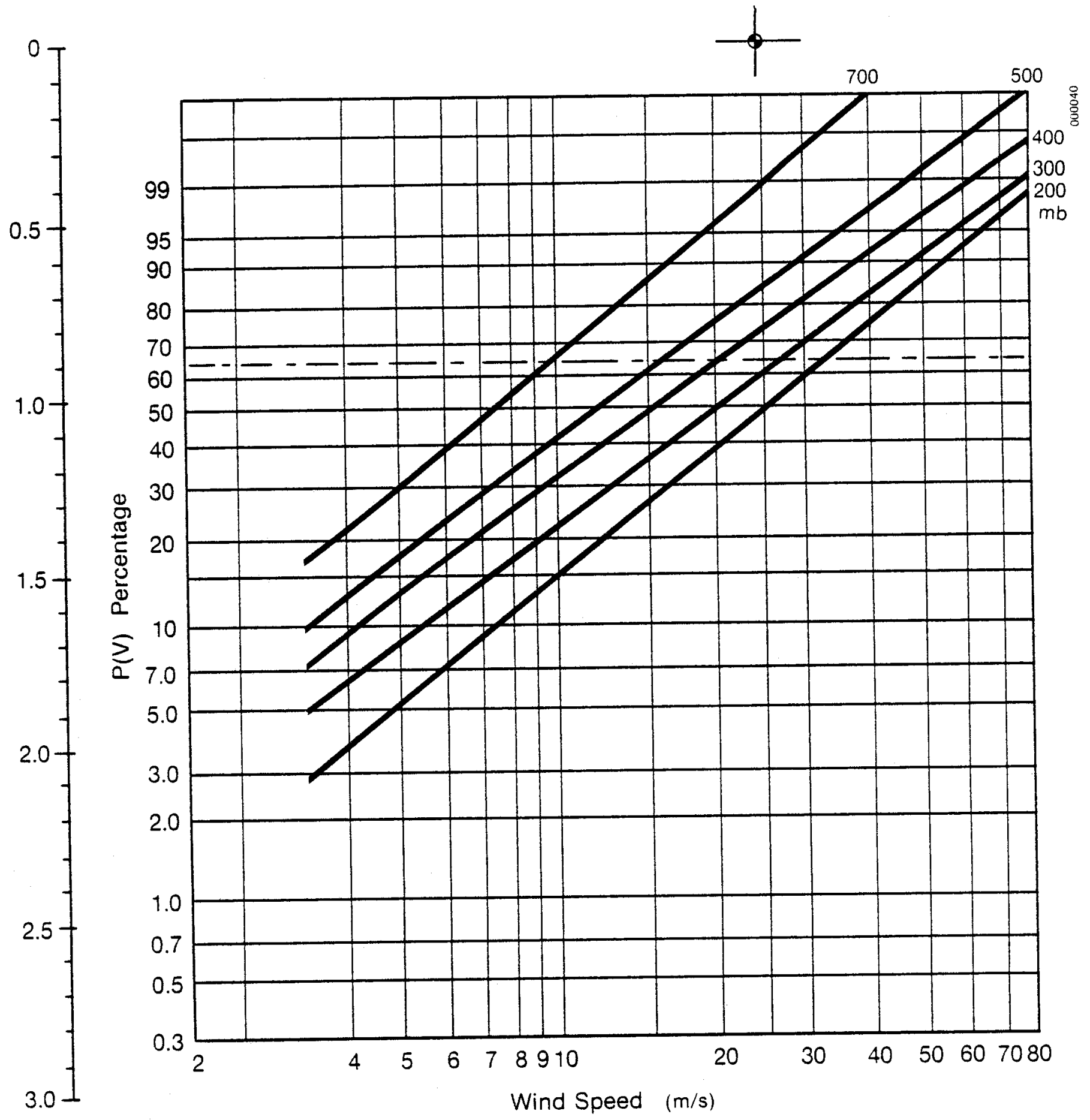

Figure B-27. Annual Probability Distribution of Velocity: Midland, TX 


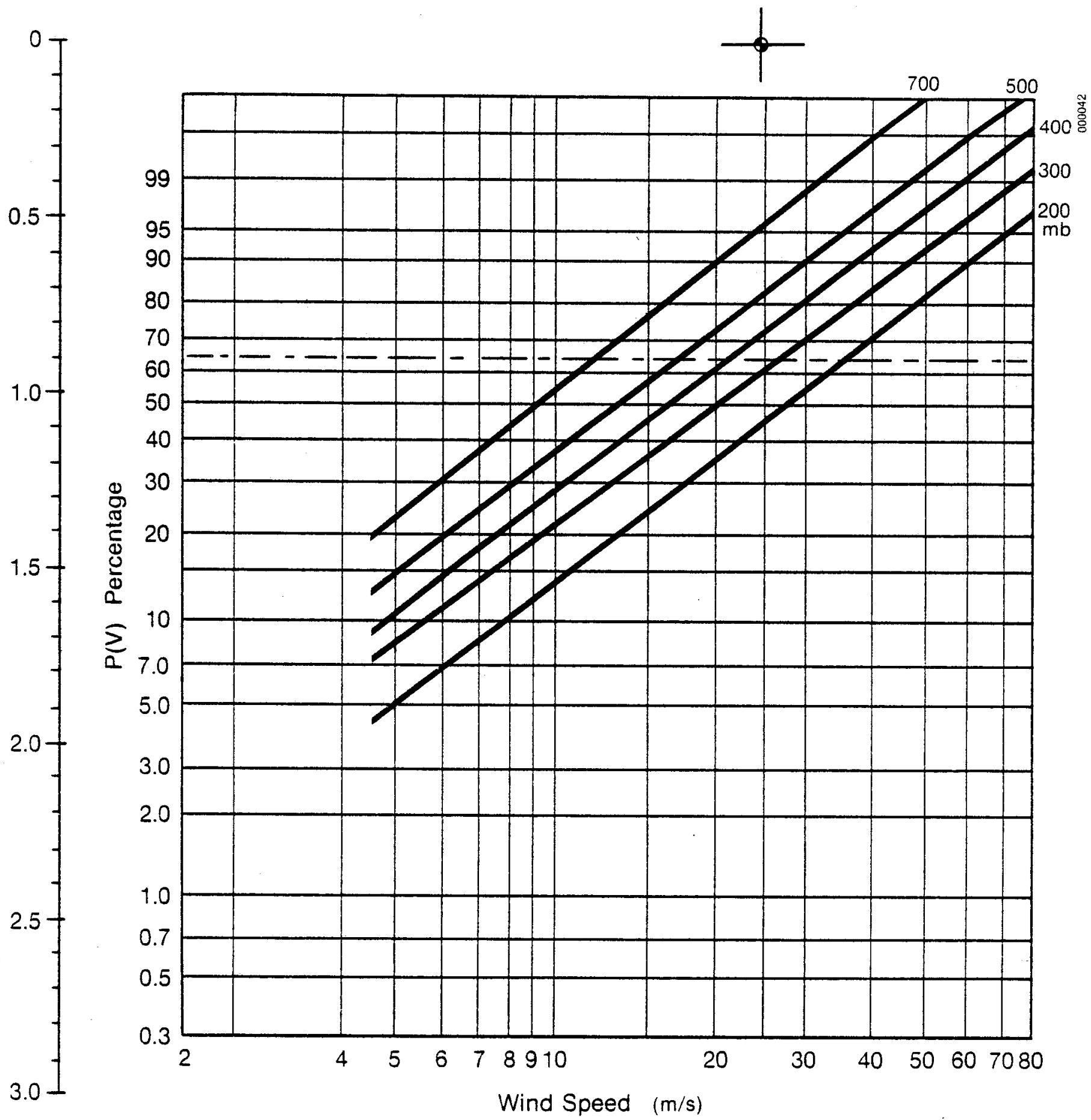

Figure B-28. Annual Probability Distribution of Velocity: Montgomery, AL 


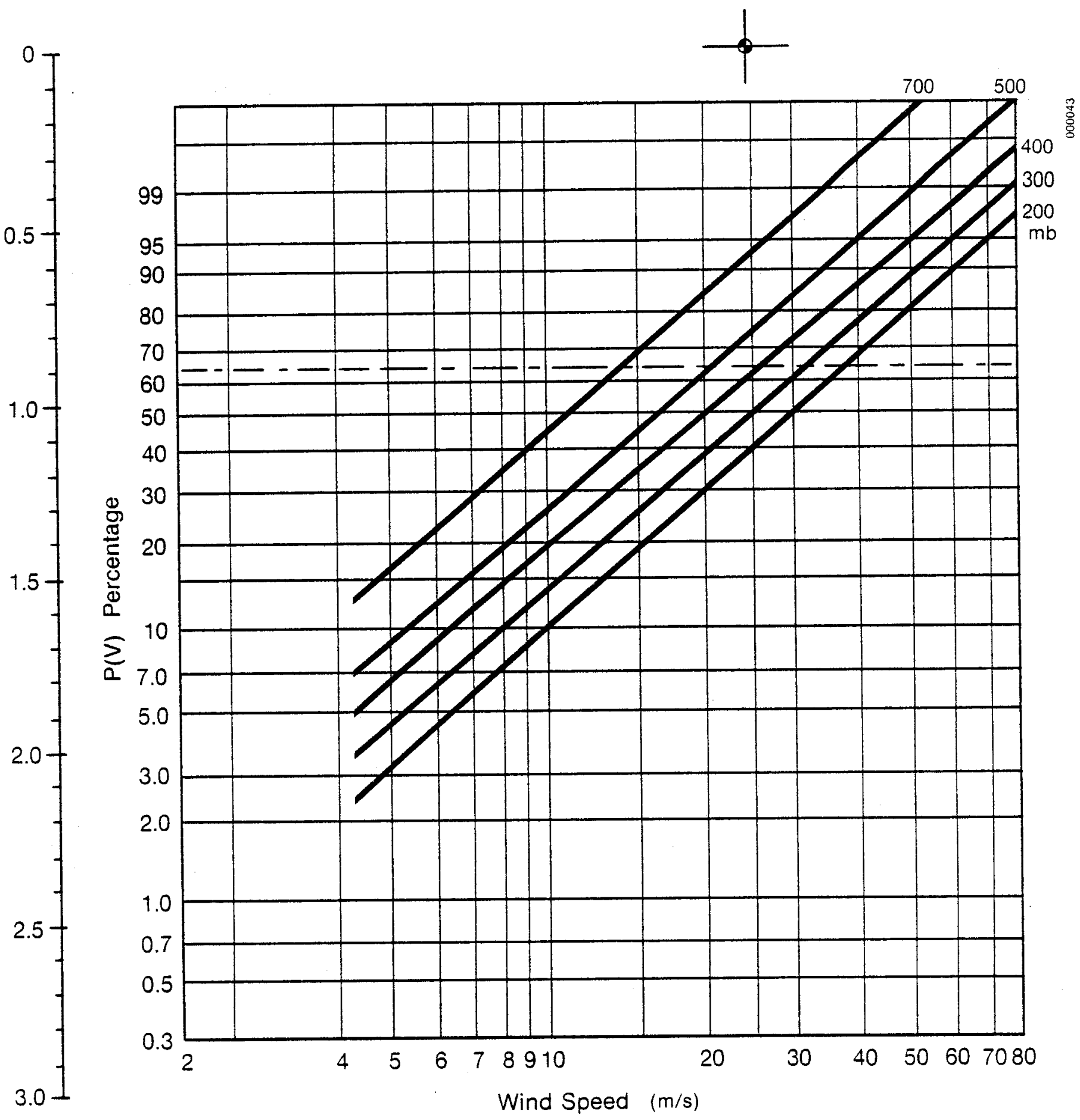

Figure B-29. Annual Probability Distribution of Velocity: Nashville, TN 


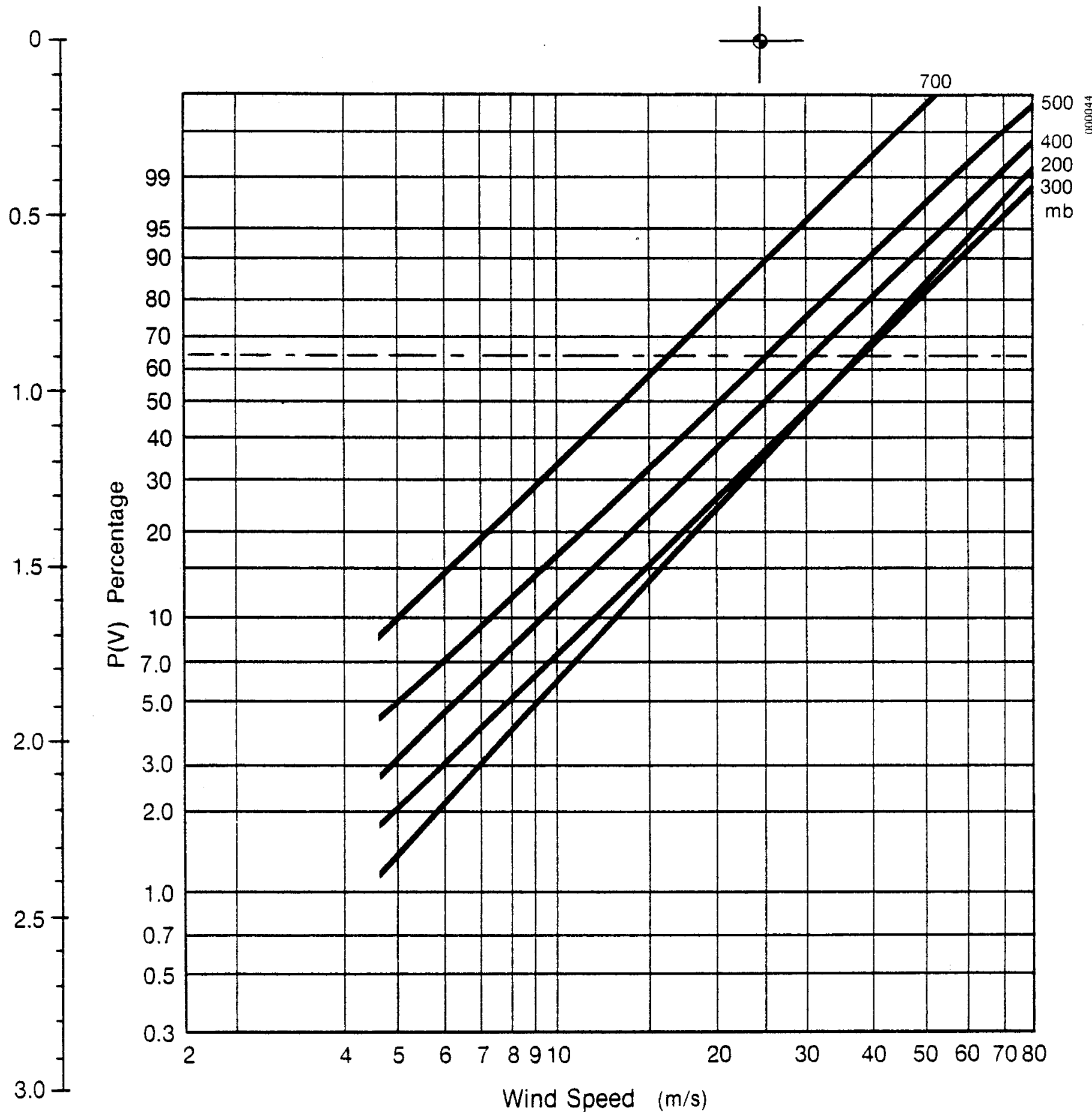

Figure B-30. Annual Probability Distribution of Velocity: New York, NY 


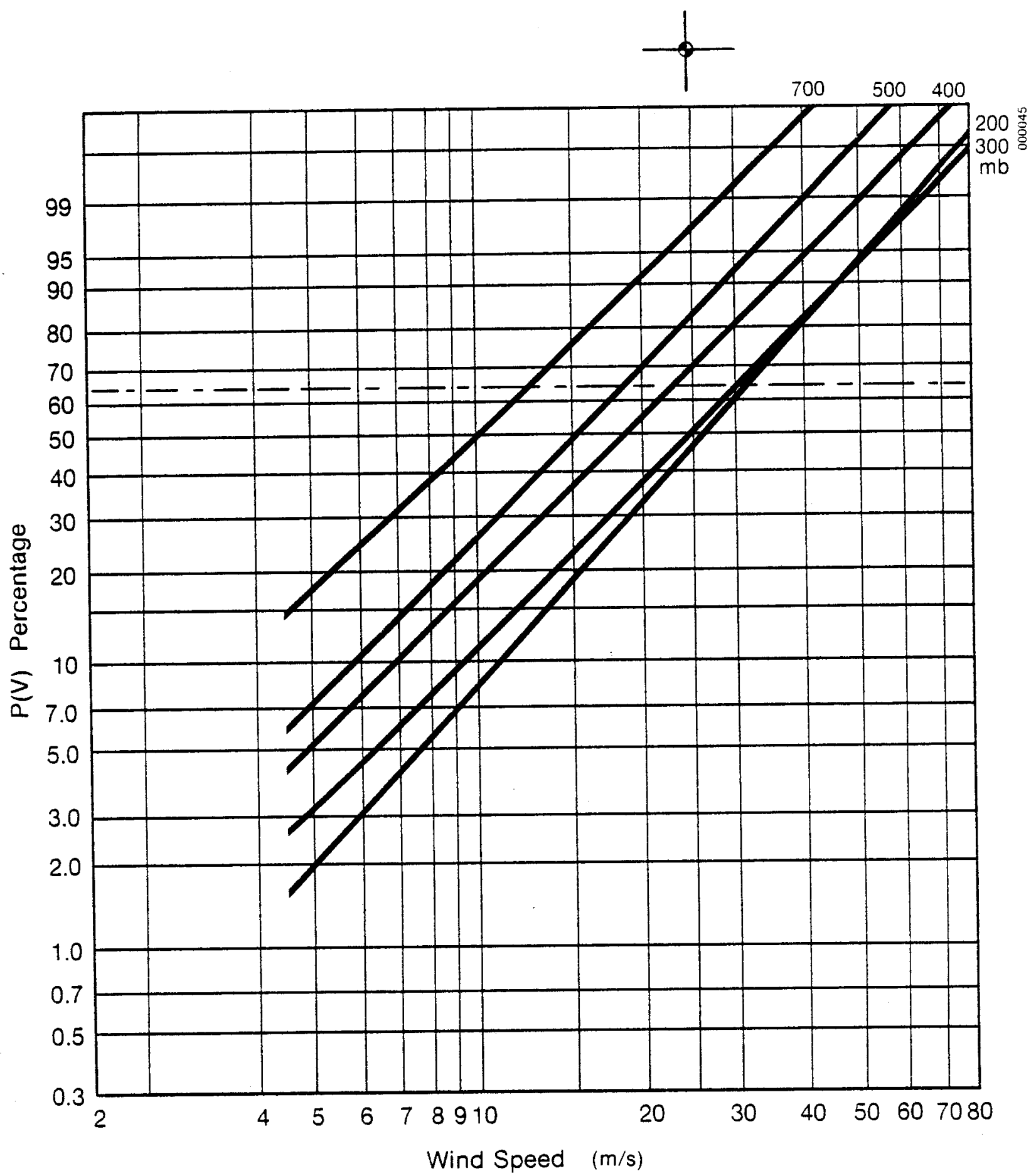

Figure B-31. Annual Probability Distribution of Velocity: North Platte, NE 


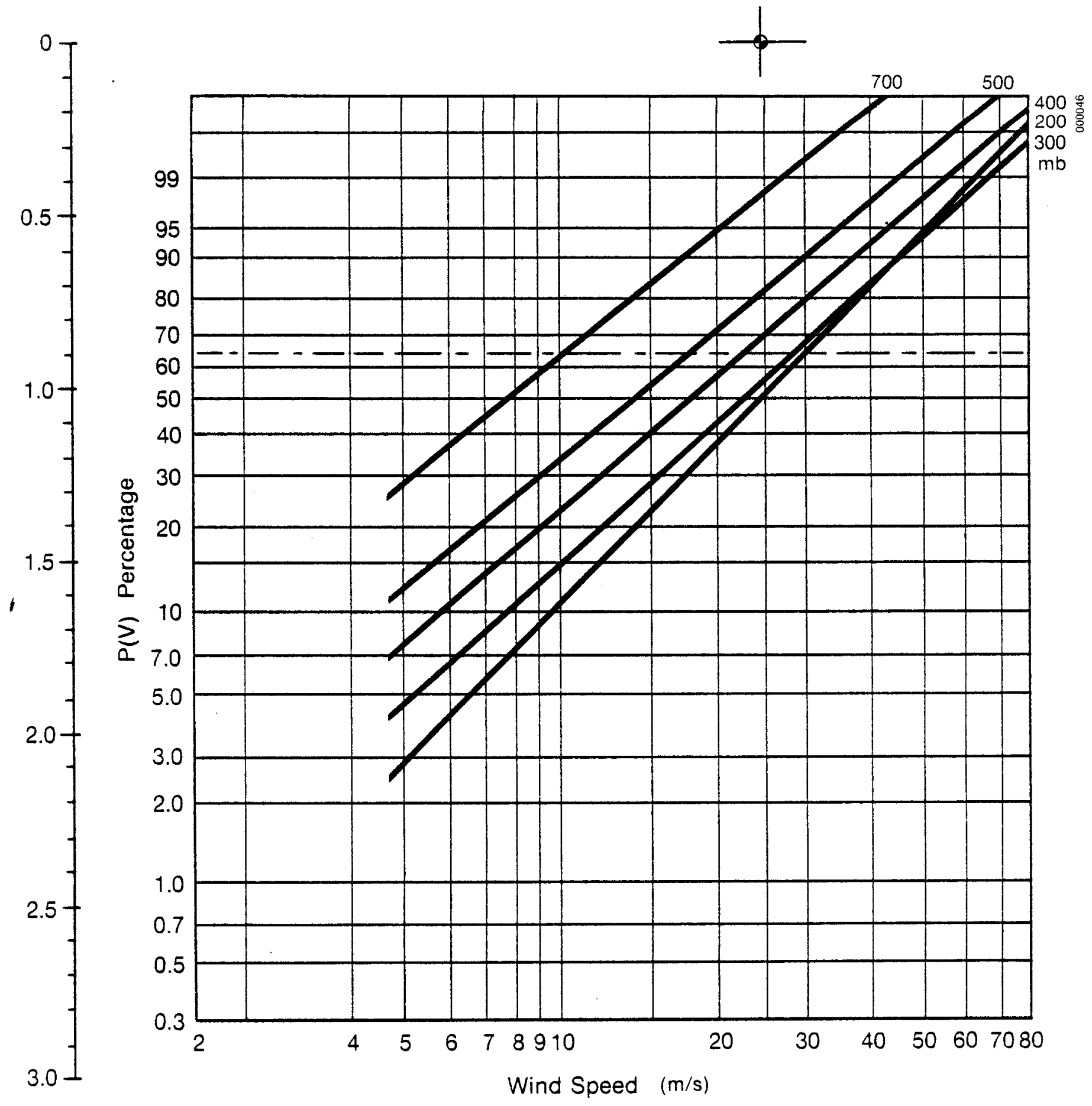

Figure B-32. Annual Probability Distribution of Velocity: Oakland, CA 


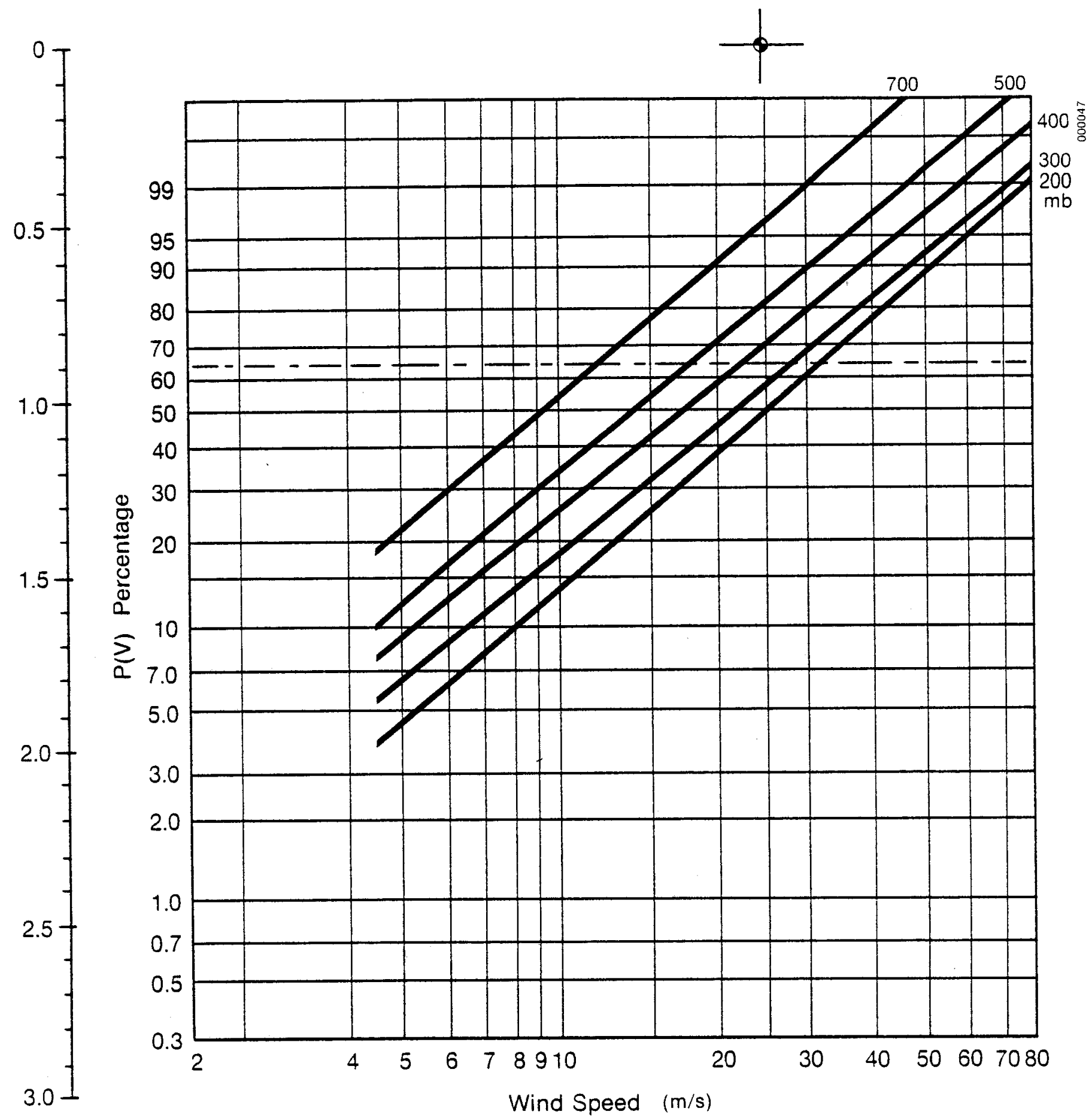

Figure B-33. Annual Probability Distribution of Velocity: Oklahoma City, OK 


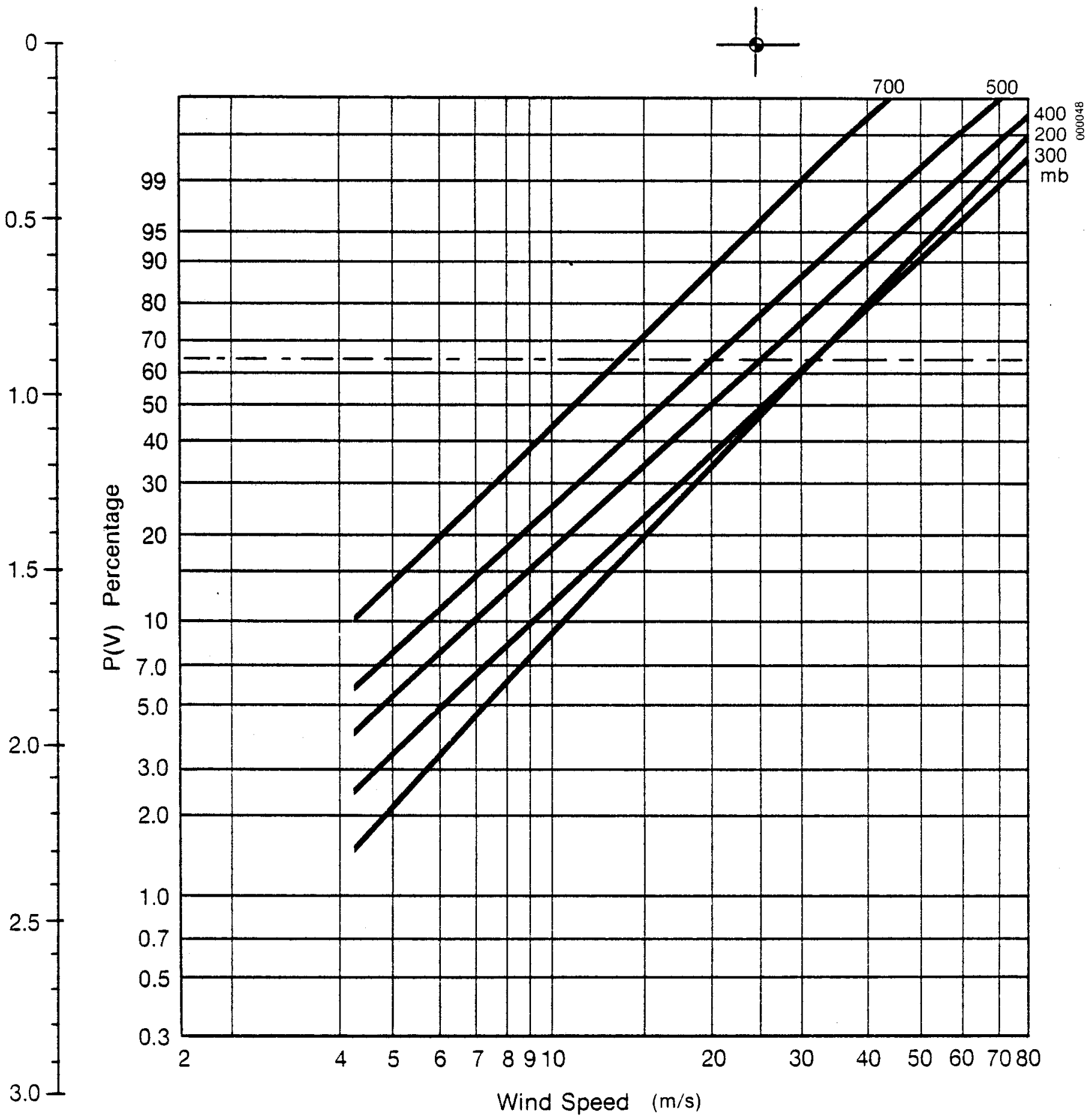

Figure B-34. Annual Probability Distribution of Velocity: Omaha, NB 


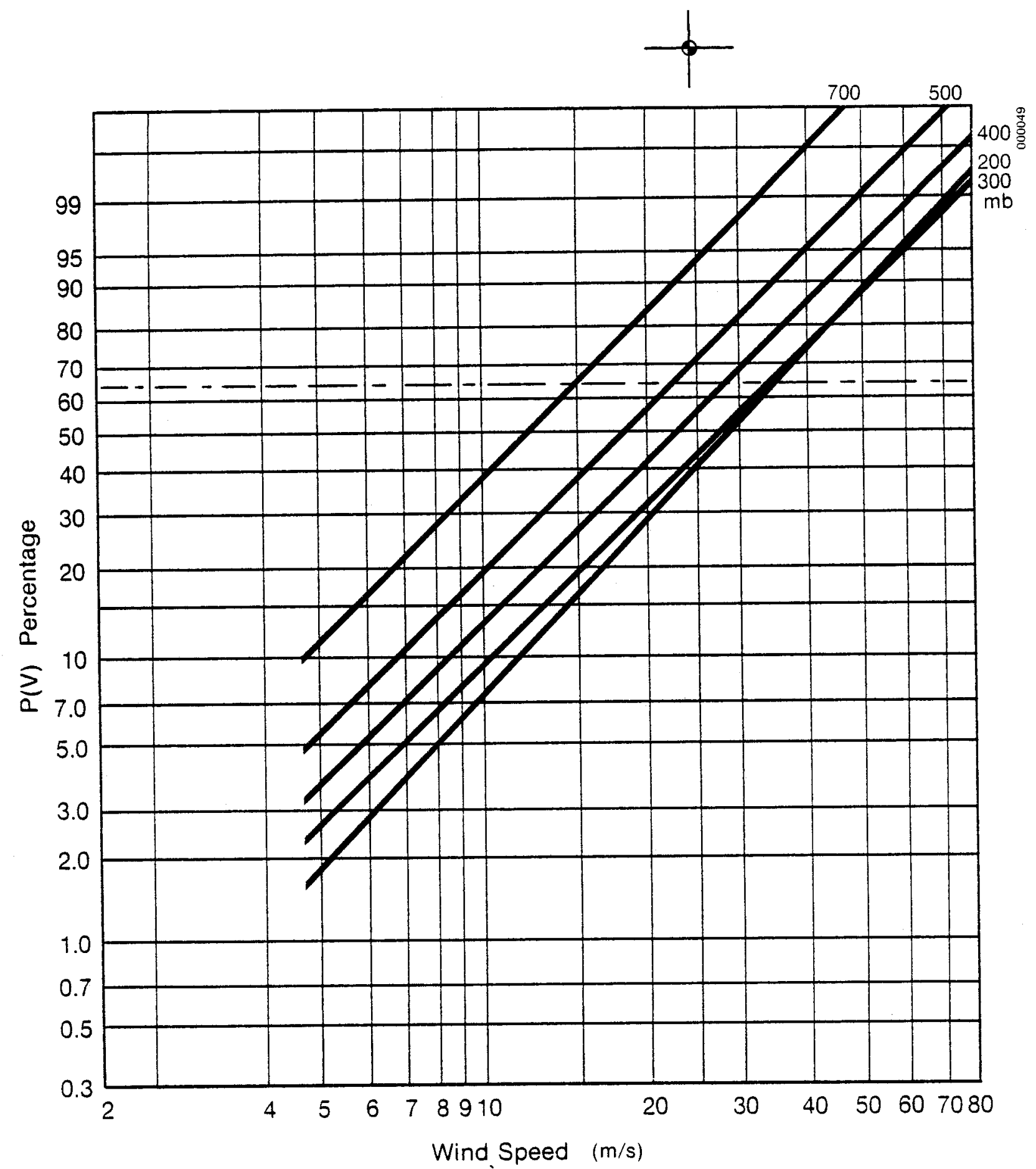

Figure B-35. Annual Probability Distribution of Velocity: Peoria, IL 


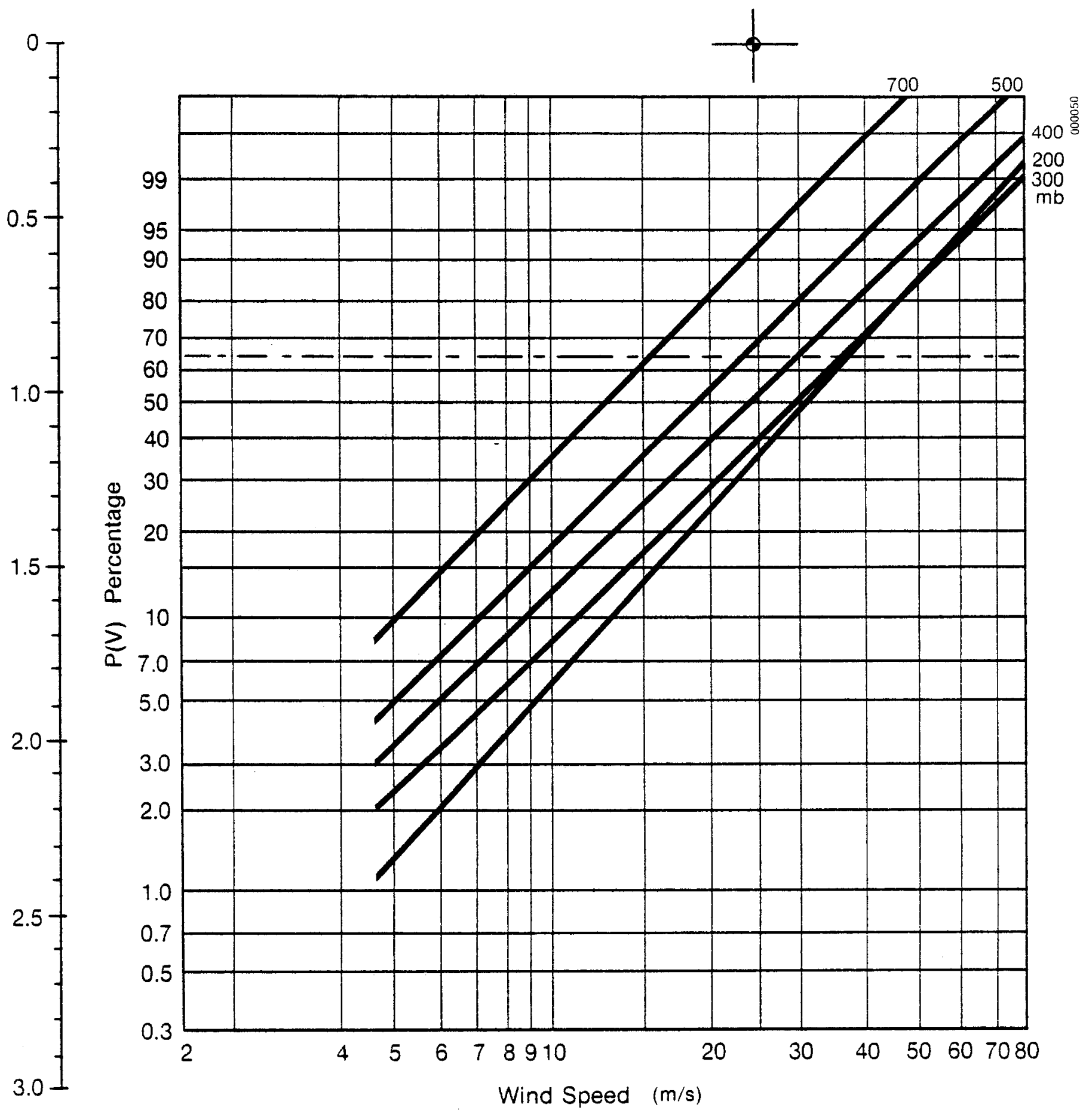

Figure B-36. Annual Probability Distribution of Velocity: Pittsburgh, PA 


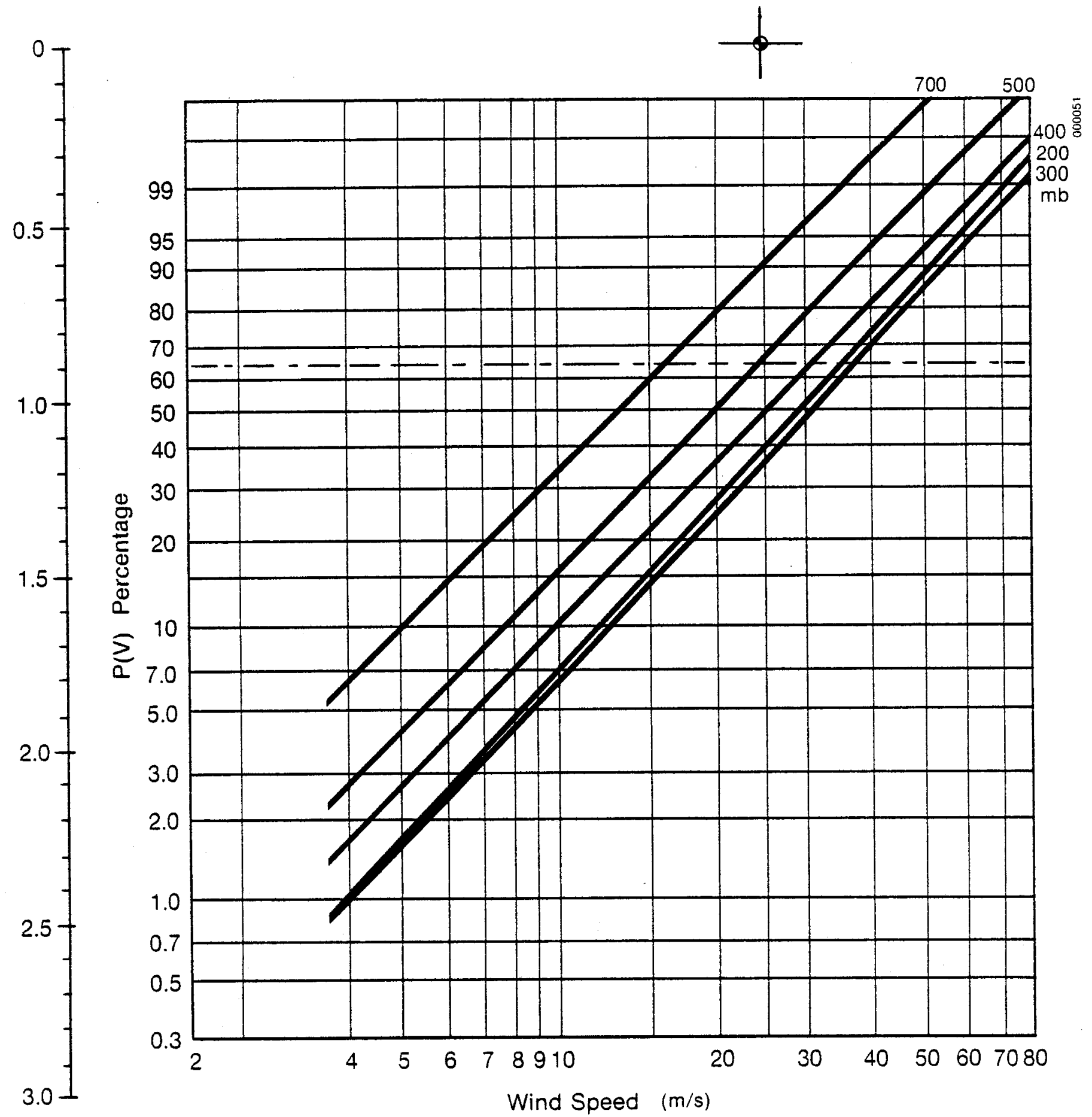

Figure B-37. Annual Probability Distribution of Velocity: Portland, ME 


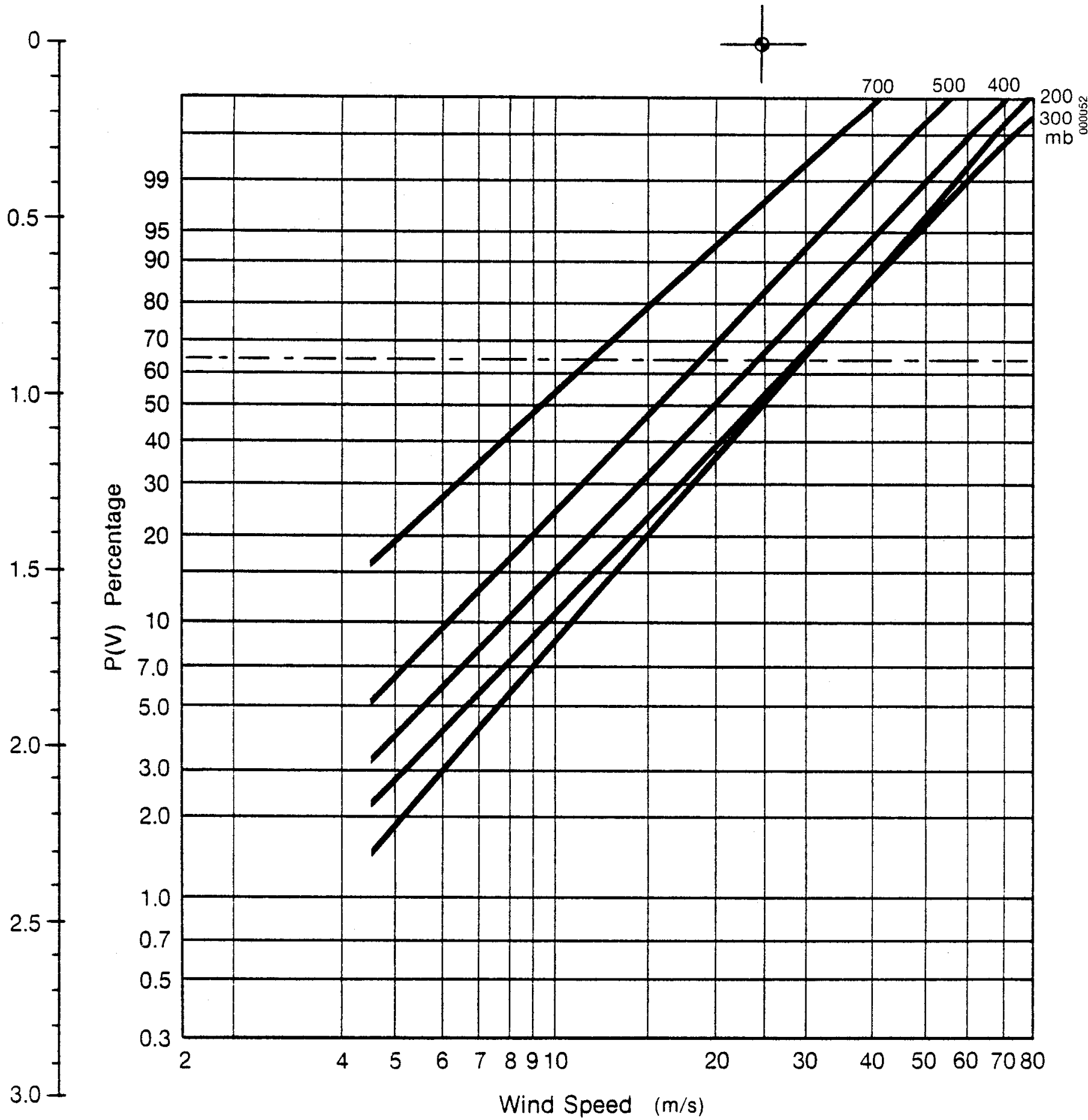

Figure B-38. Annual Probability Distribution of Velocity: Rapid City, SD 


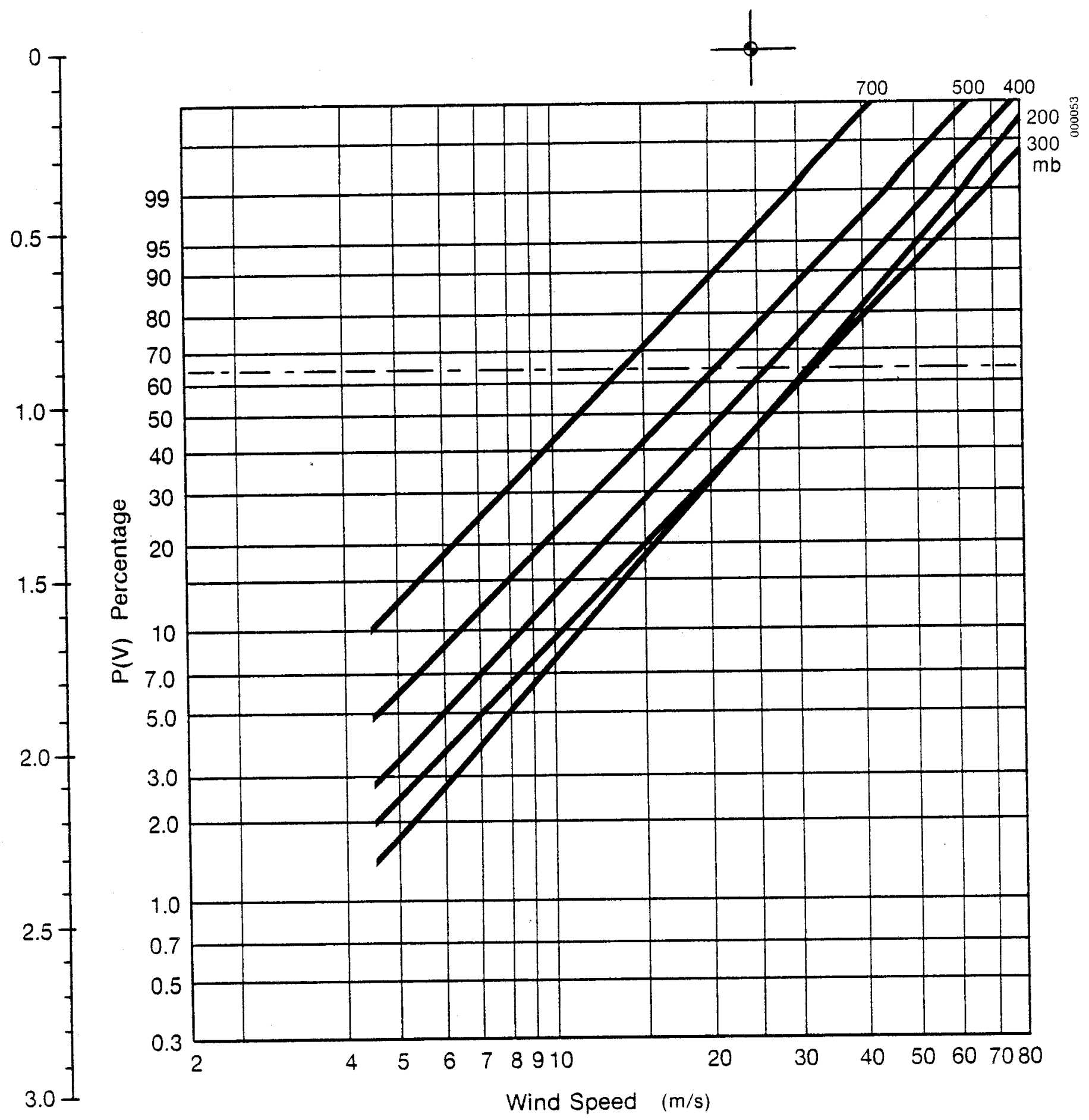

Figure B-39. Annual Probability Distribution of Velocity: St. Cloud, MN 


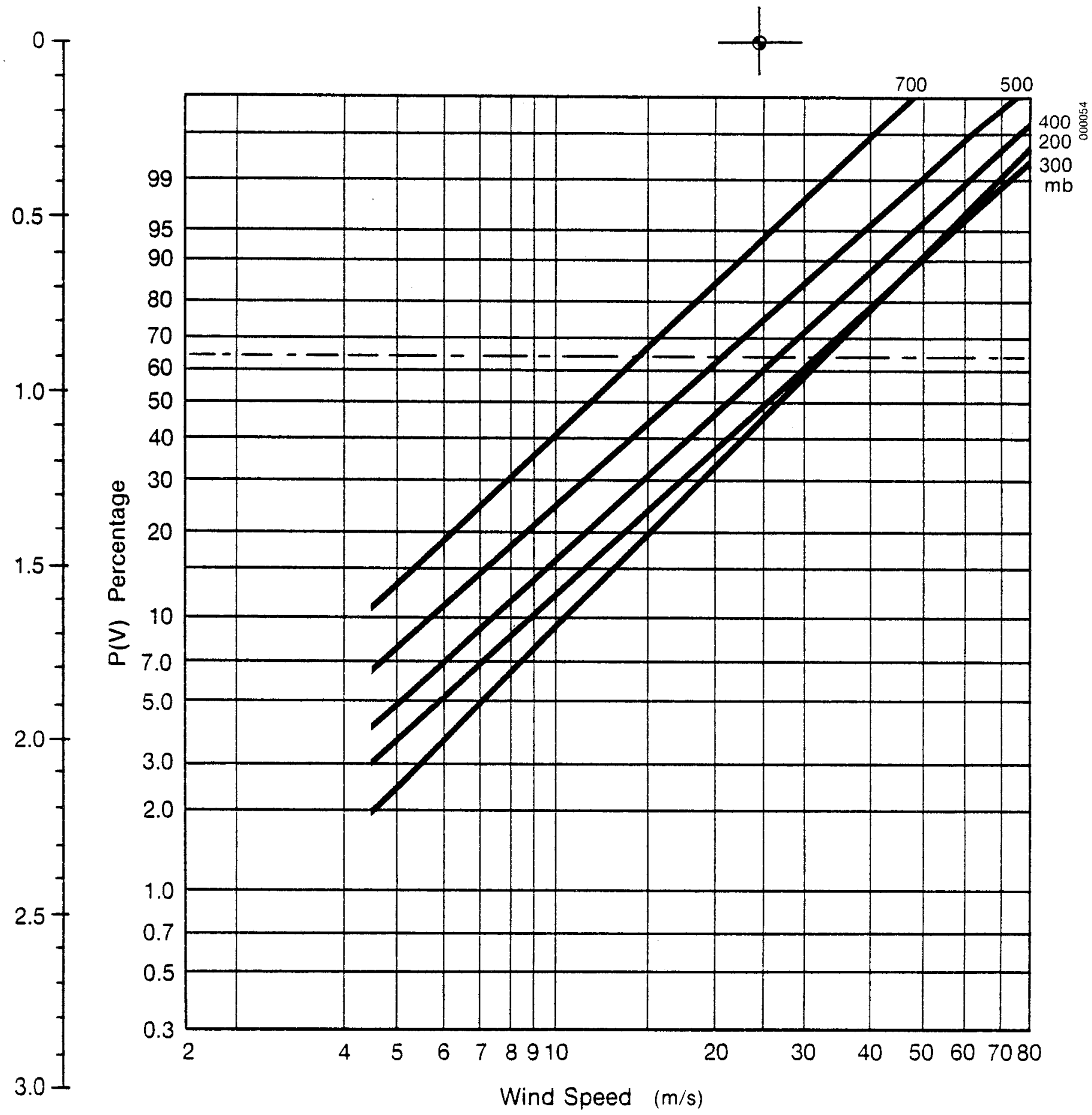

Figure B-40. Annual Probability Distribution of Velocity: Salem, IL 


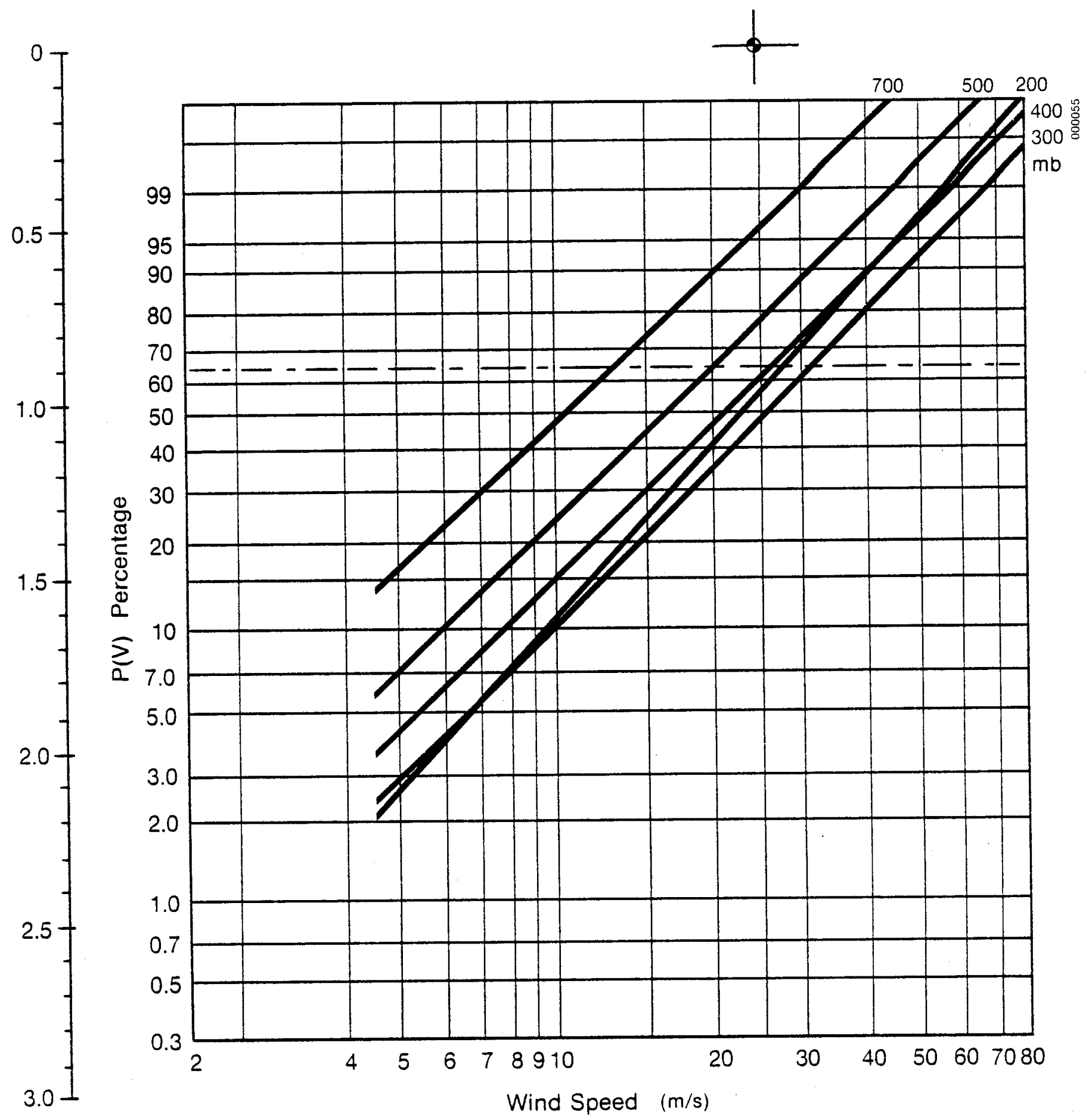

Figure B-41. Annual Probability Distribution of Velocity: Salem, OR 


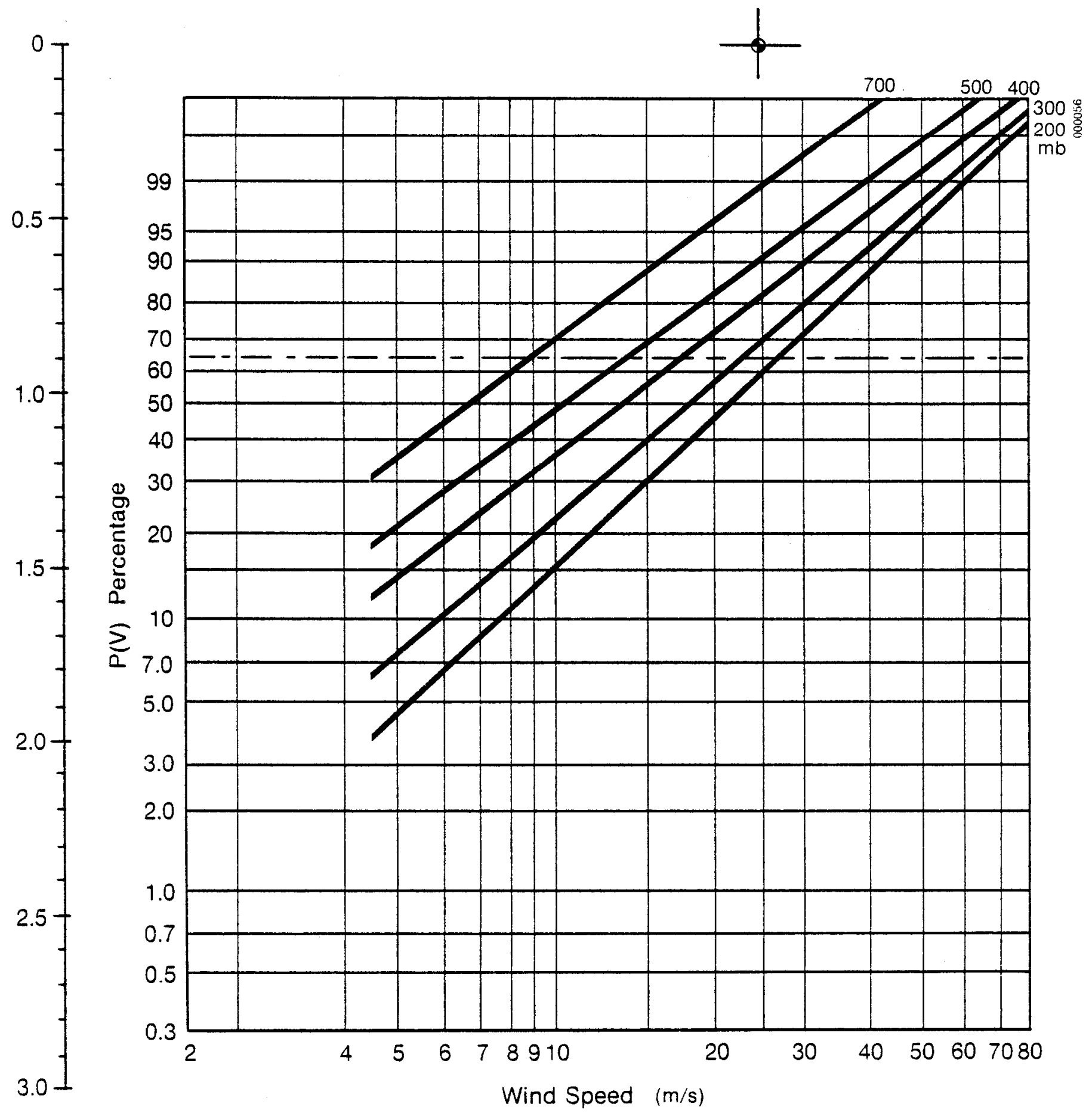

Figure B-42. Annual Probability Distribution of Velocity: San Nichols Island, CA 


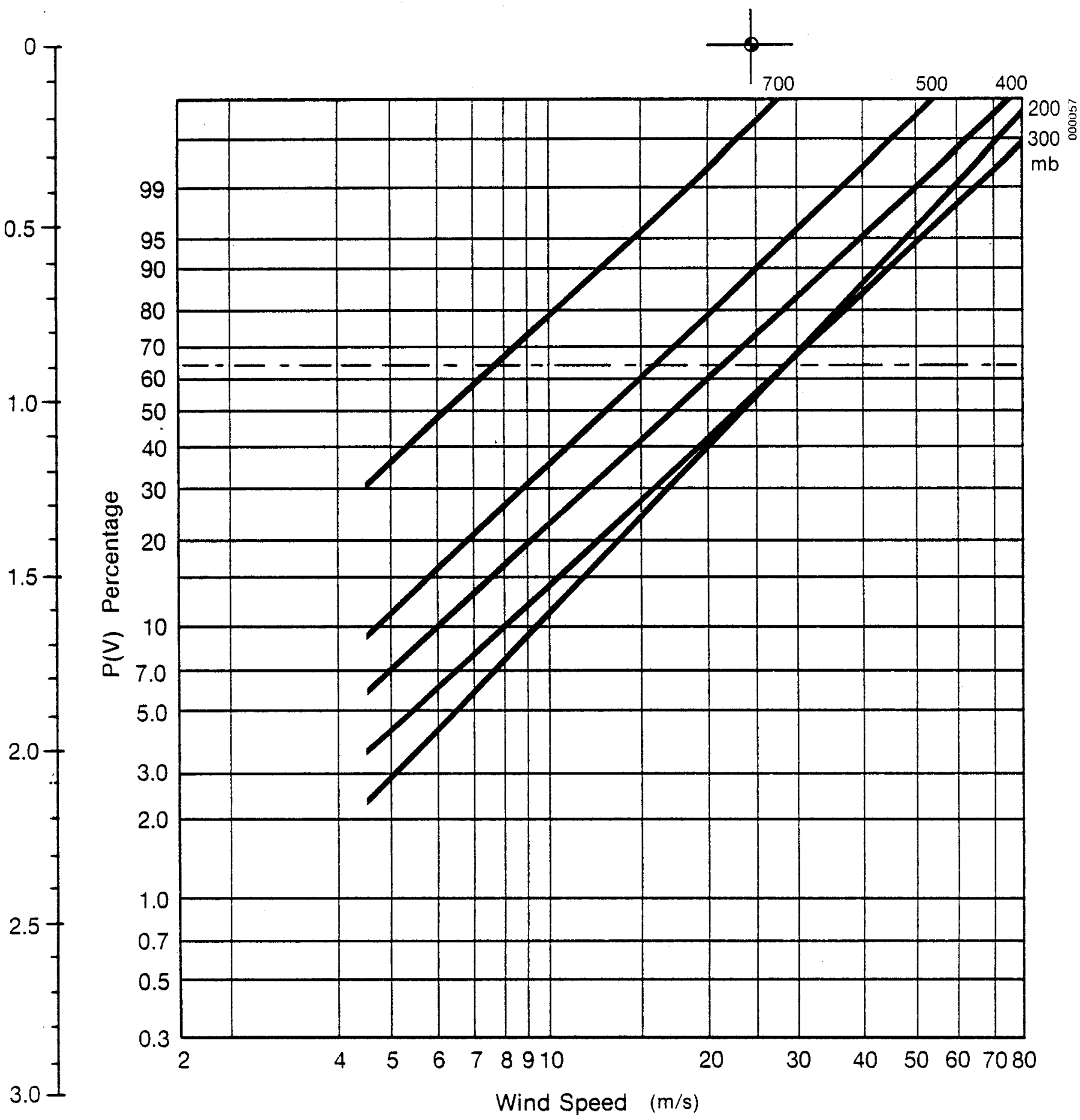

Figure B-43. Annual Probability Distribution of Velocity: Salt Lake City, UT 


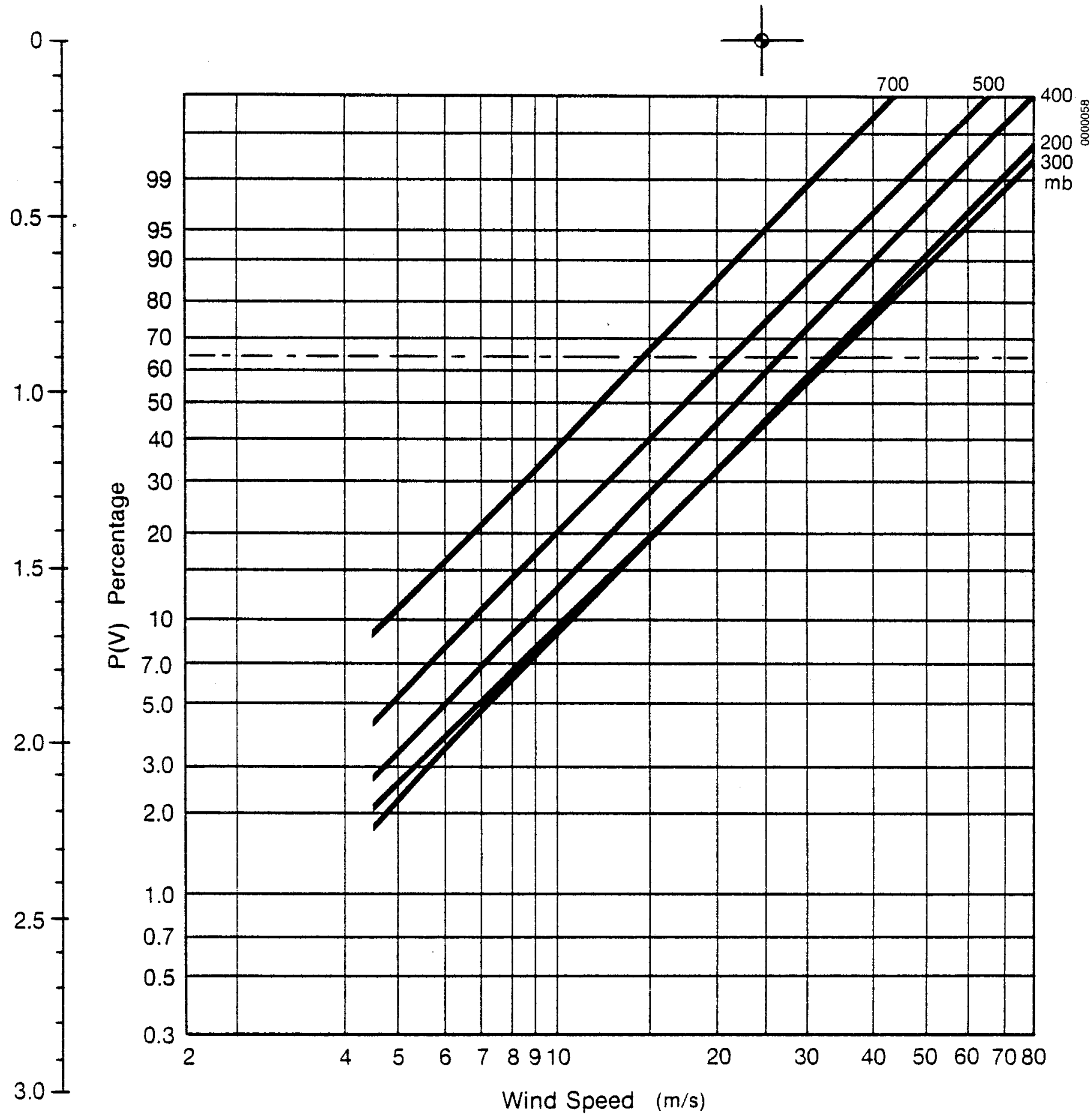

Figure B-44. Annual Probability Distribution of Velocity: Sault Ste. Marie, MI 


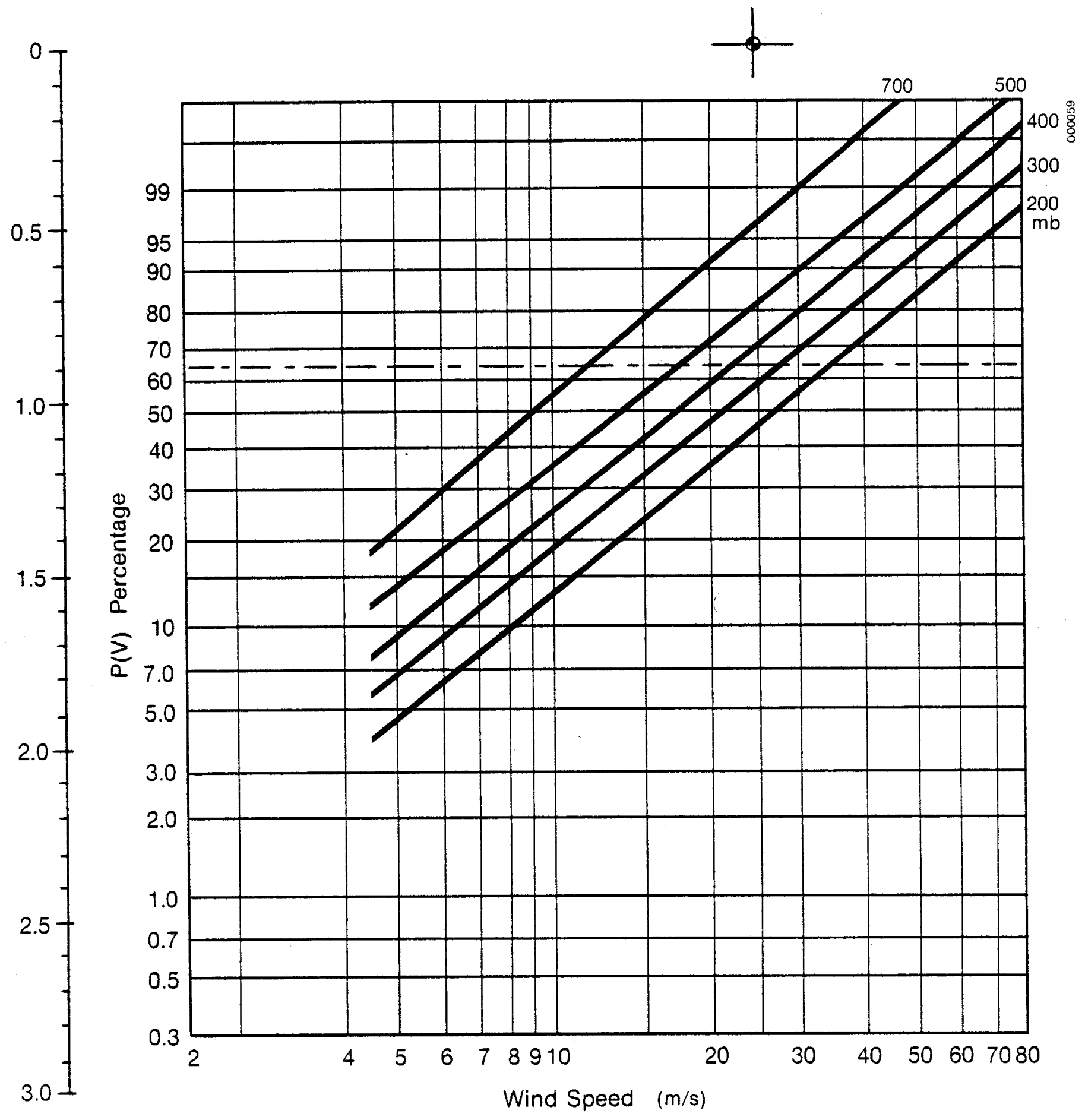

Figure B-45. Annual Probability Distribution of Velocity: Shreveport, LA 


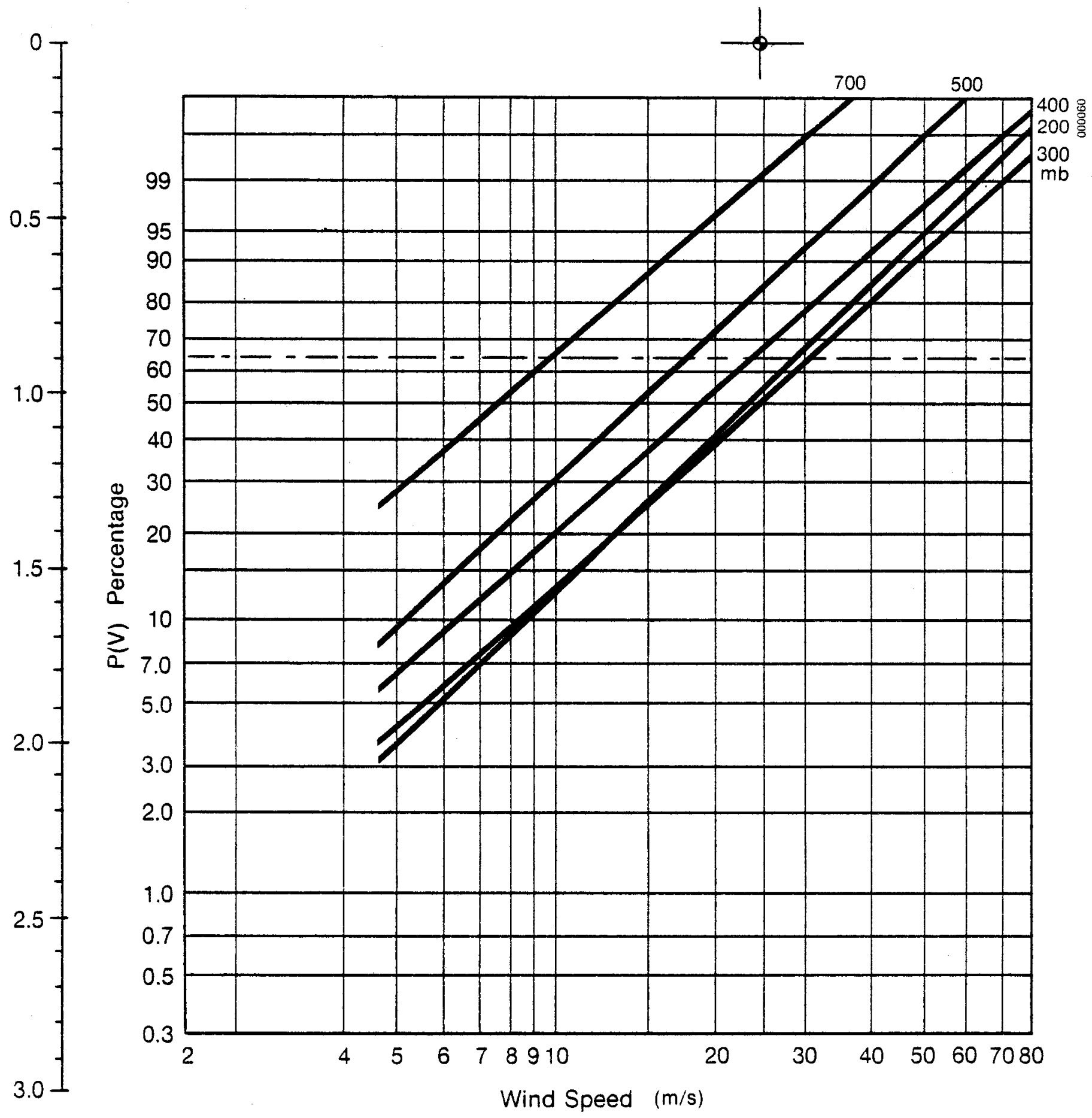

Figure B-46. Annual Probability Distribution of Velocity: Spokane, WA 


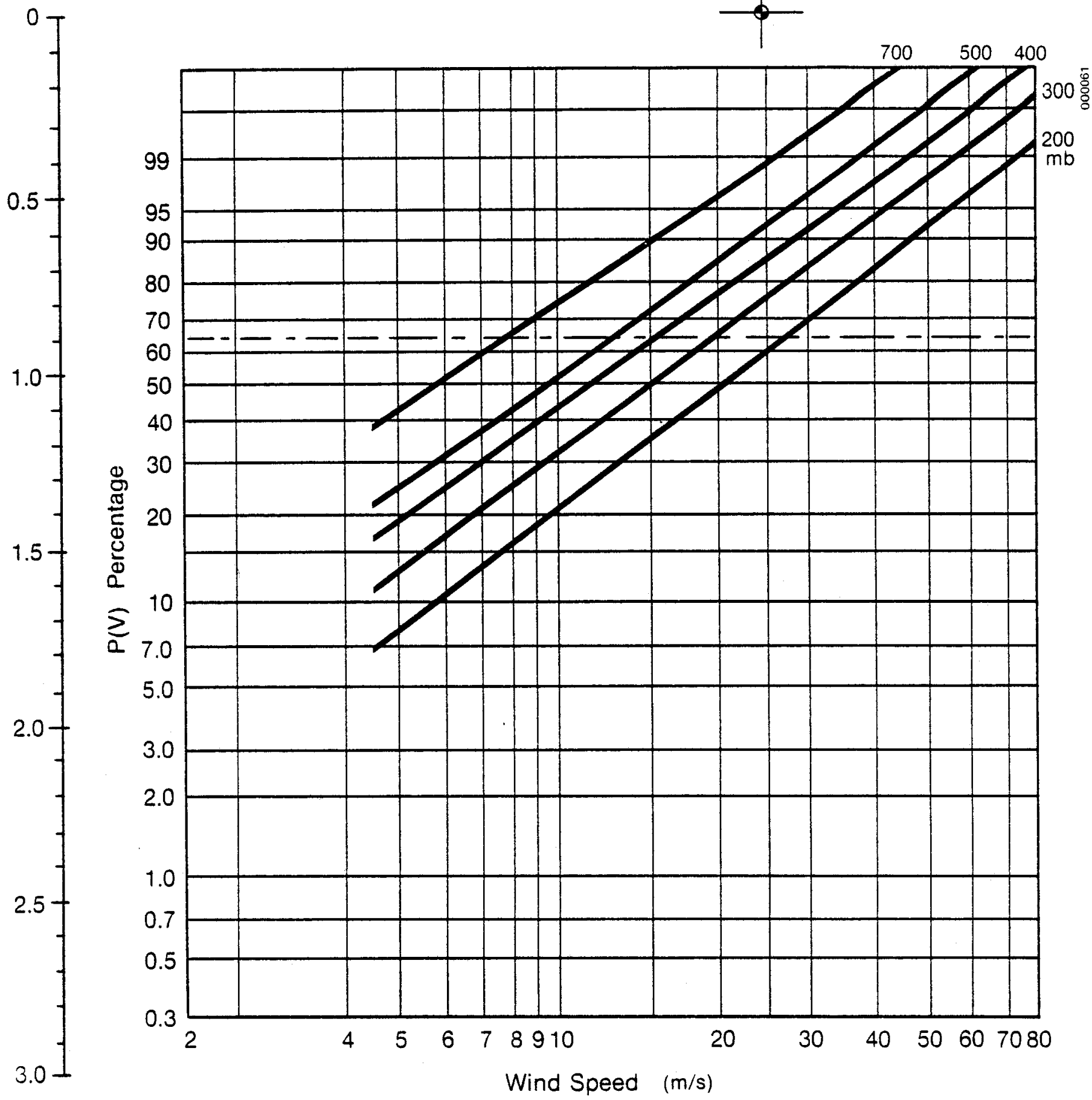

Figure B-47. Annual Probability Distribution of Velocity: Tampa, FL 


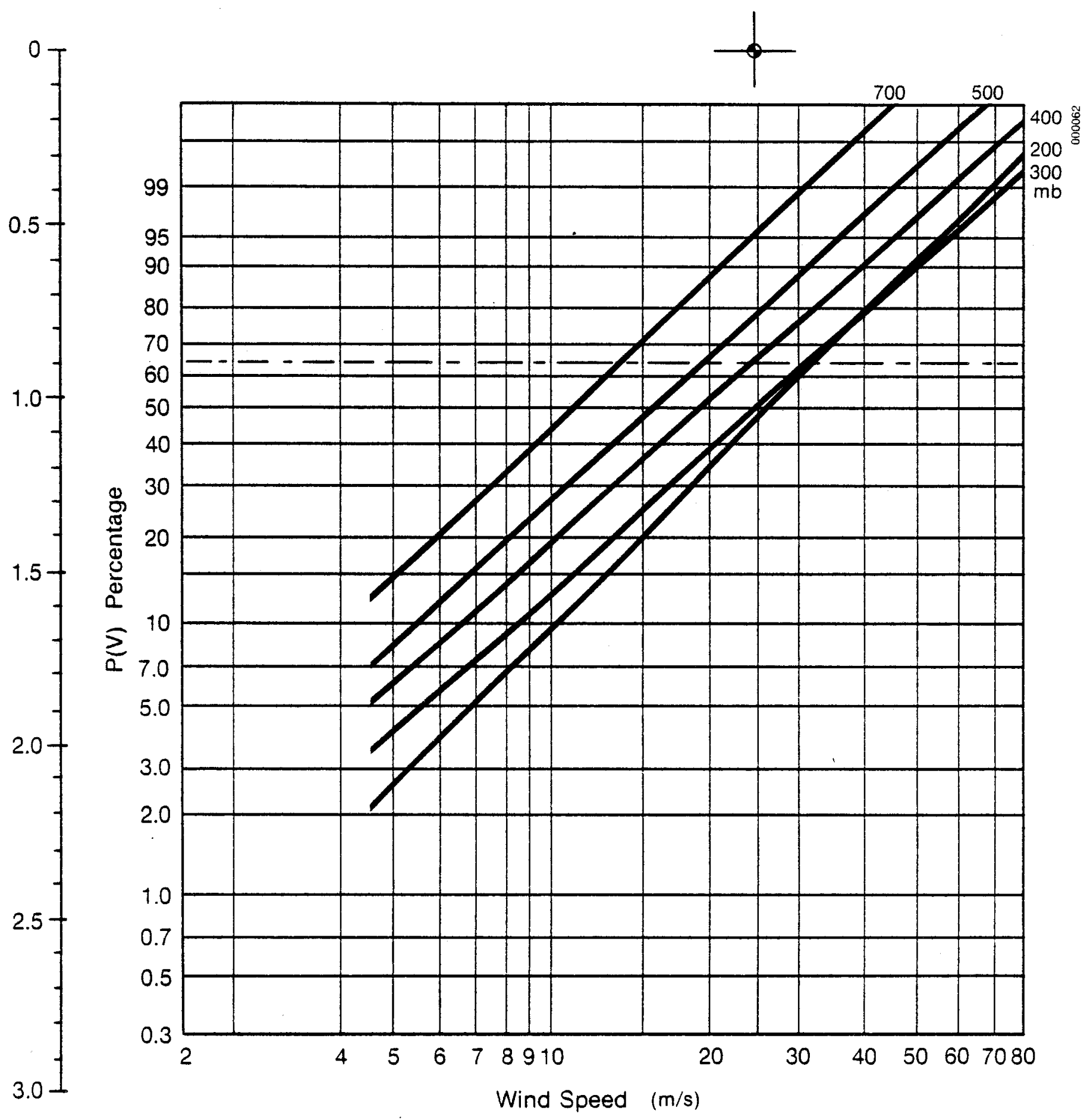

Figure B-48. Annual Probability Distribution of Velocity: Topeka, KS 


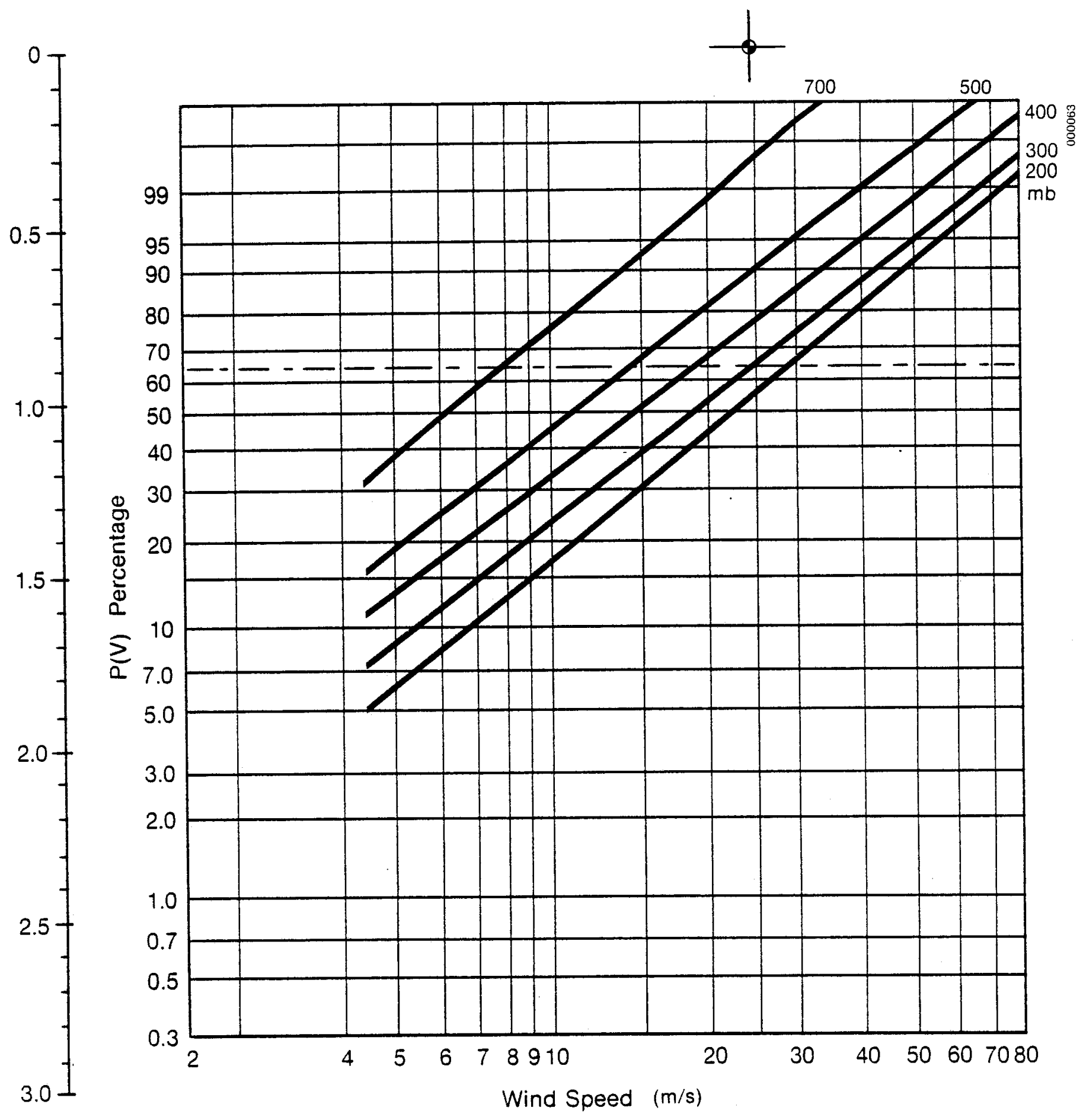

Figure B-a9. Annual Probability Distribution of Velocity: Tucson, AZ 


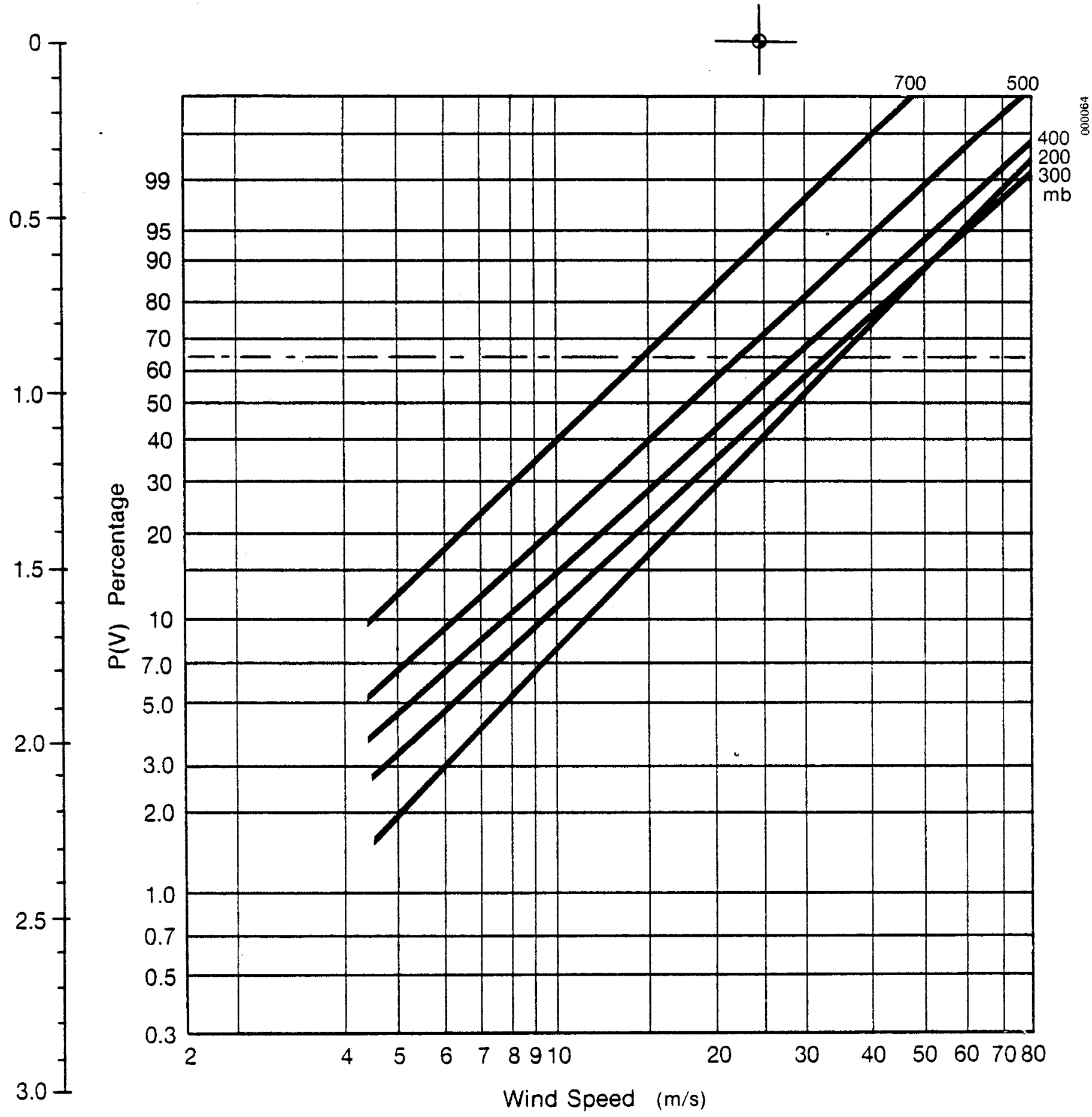

Figure B-50. Annual Probability Distribution of Velocity: Wallops Island, VA 
T R-1400

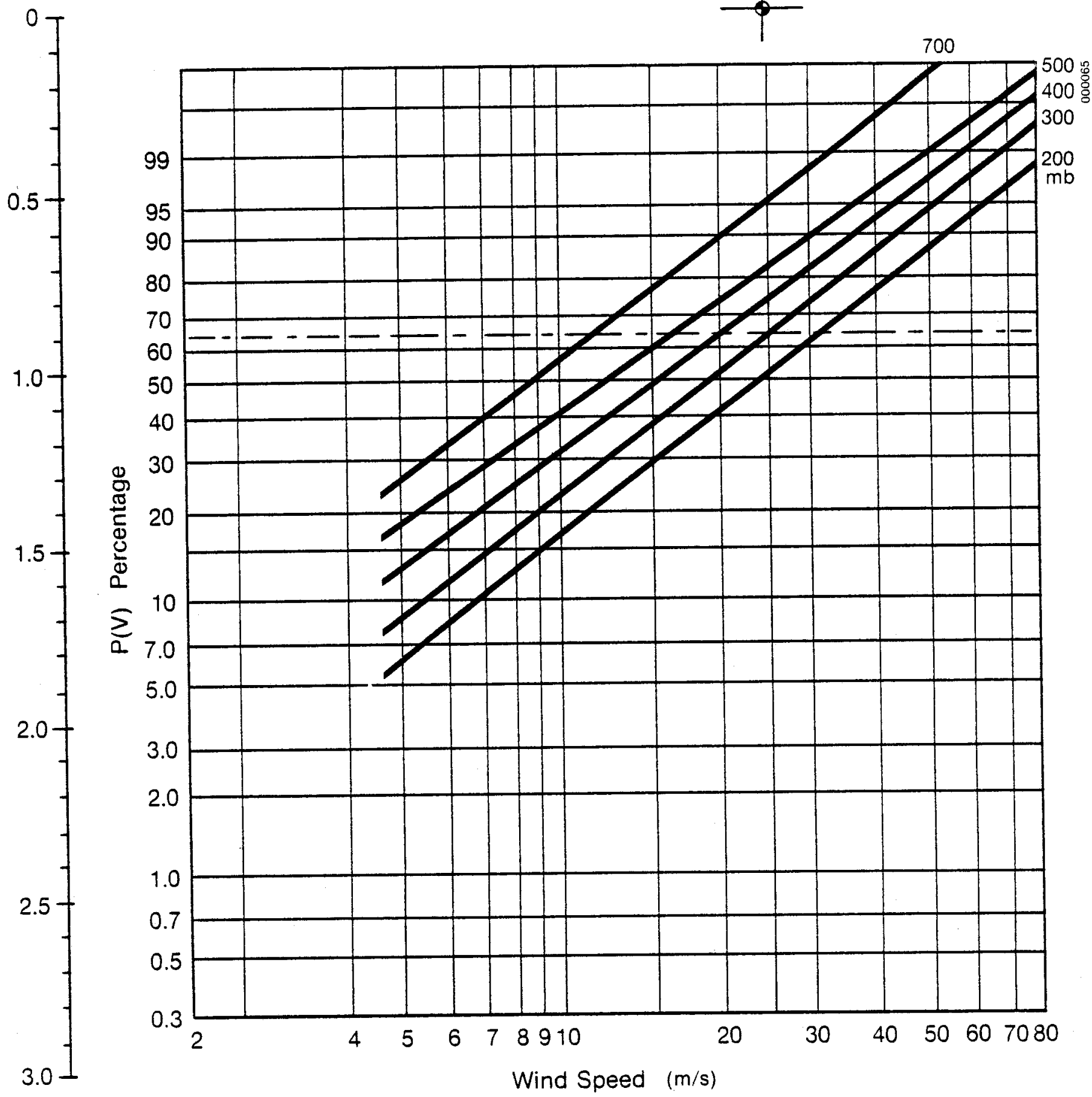

Figure B-51. Annual Probability Distribution of Velocity: Waycross, GA 


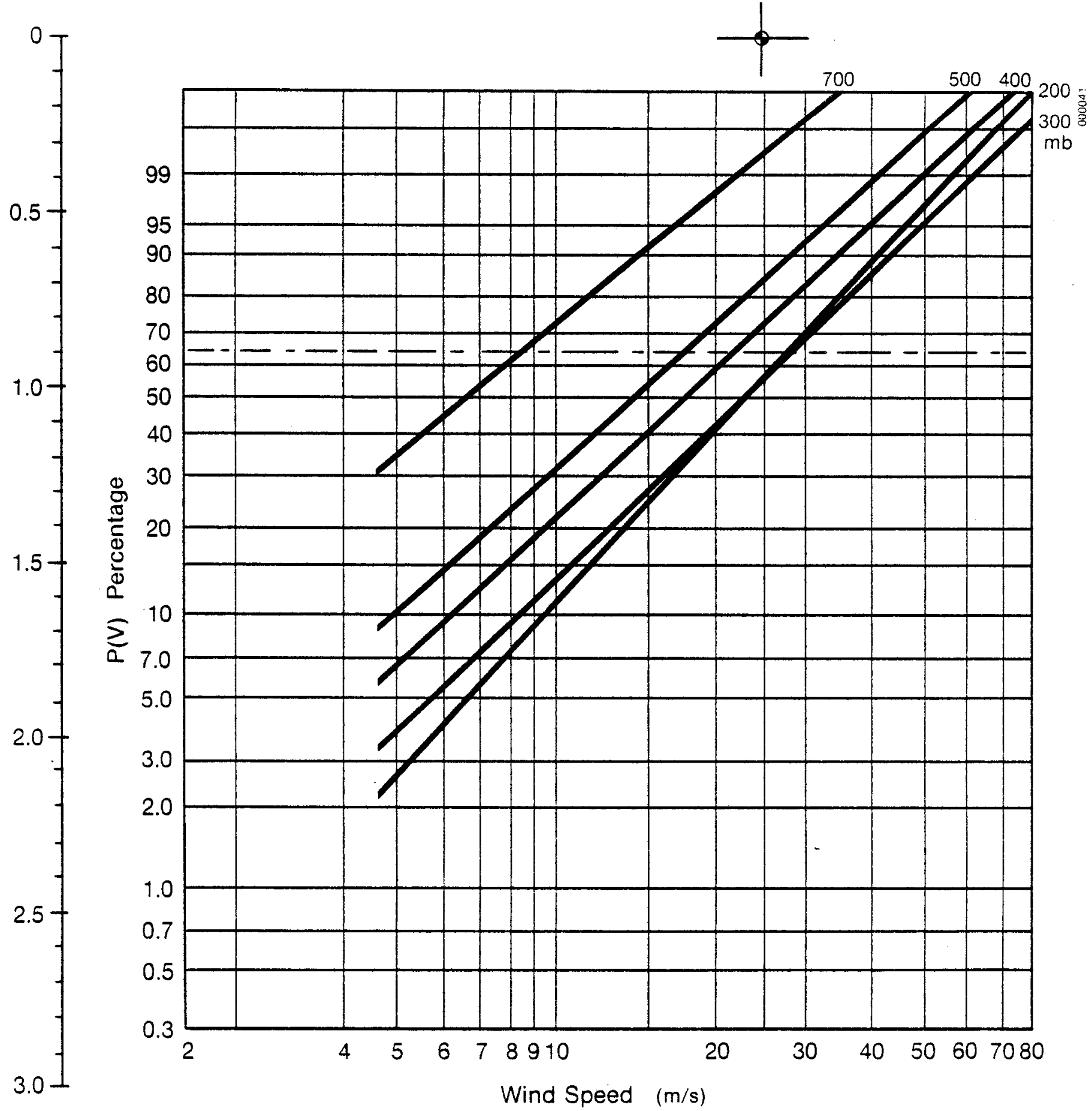

Figure B-52. Annual Probability Distribution of Velocity: Winnemucca, NV 


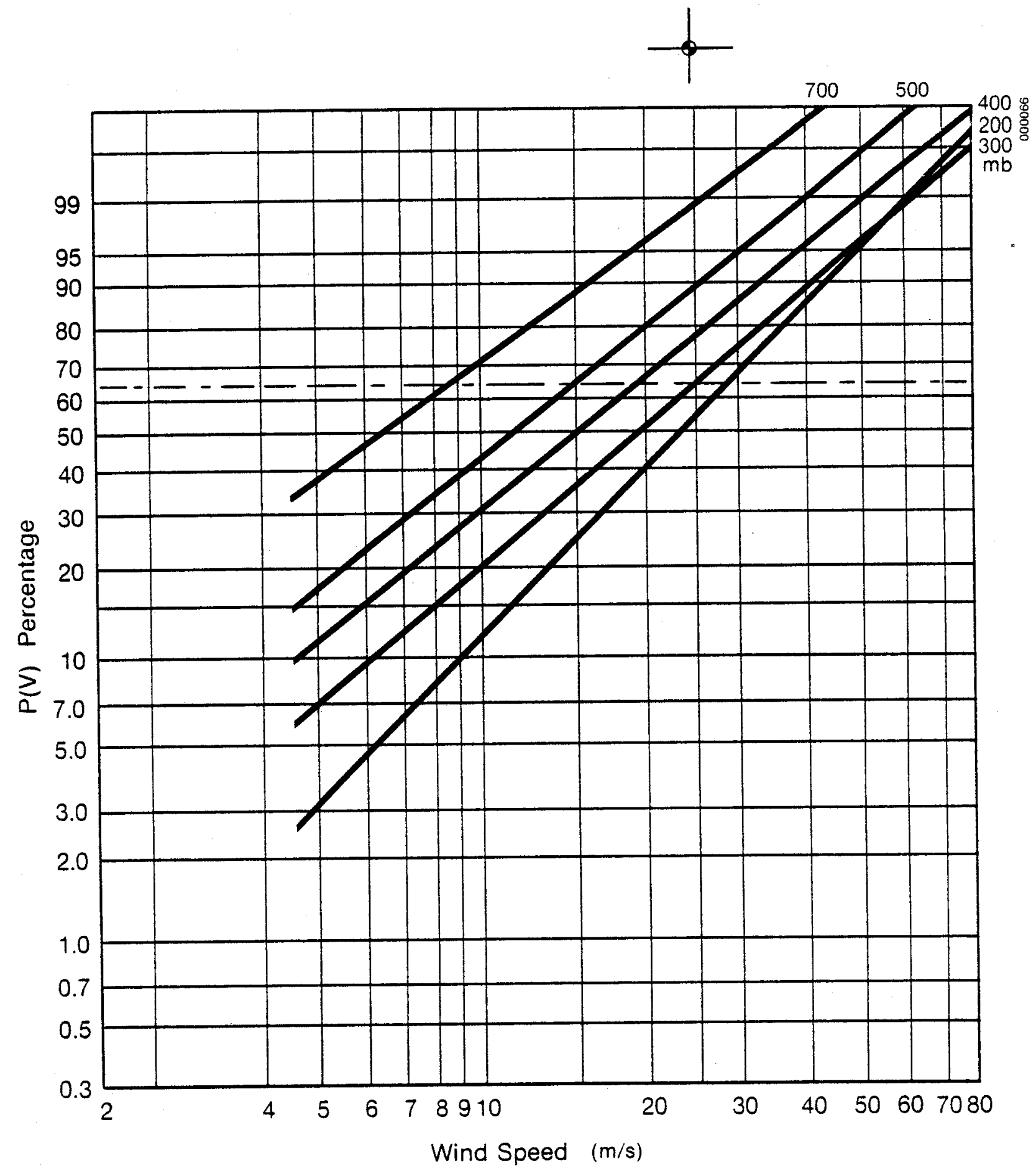

Figure B-53. Annual Probability Distribution of Velocity: Winslow, AZ 


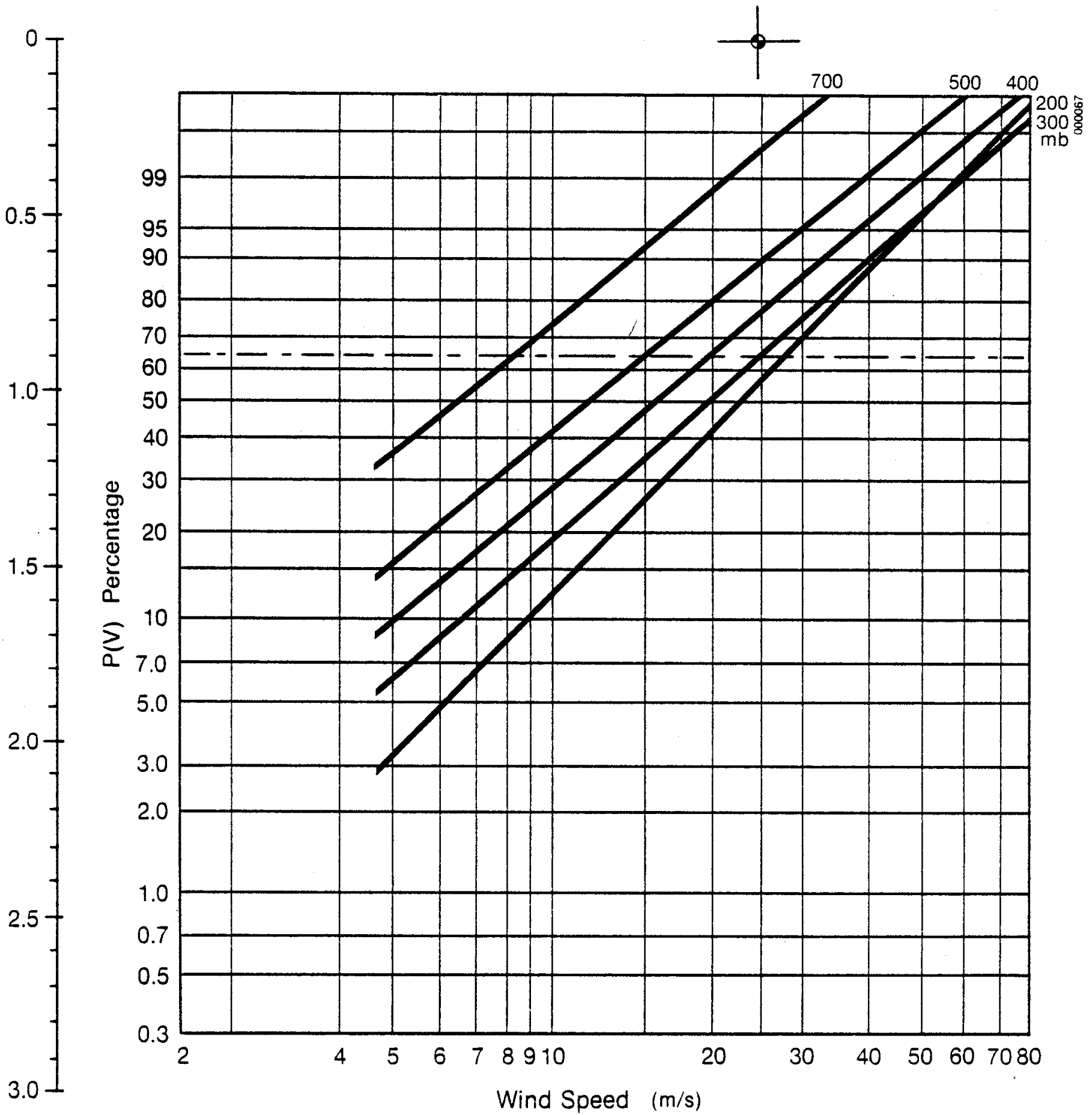

Figure B-54. Annual Probability Distribution of Velocity: Yucca Flats, NV 
APPENDIX ' $\mathrm{C}$

ANNUAL CALM-PERIOD CHARTS 


\section{SEPI}




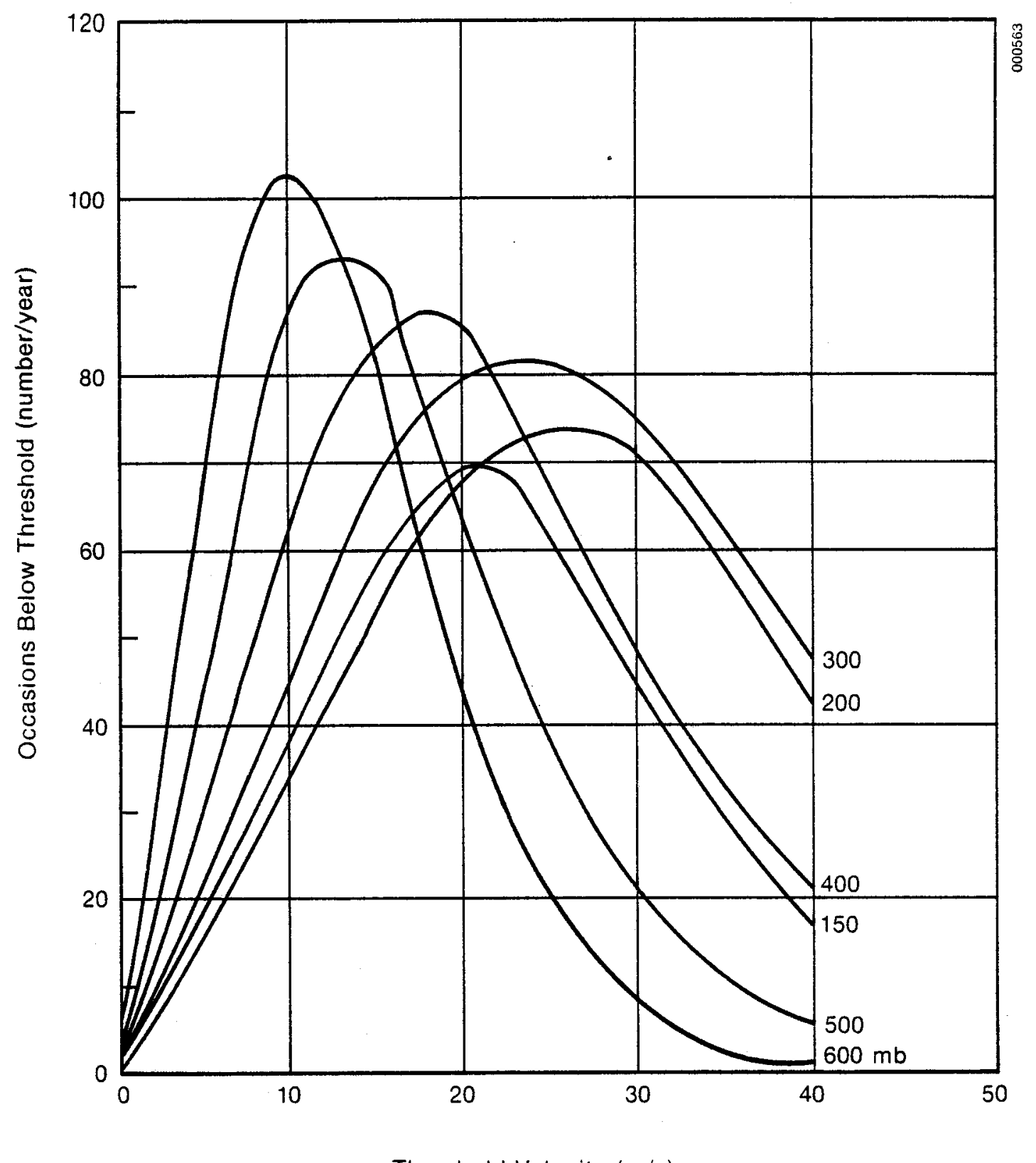

Threshold Velocity $(\mathrm{m} / \mathrm{s})$

Figure C-1. Annual Calm-Period Analysis: Denver, CO 


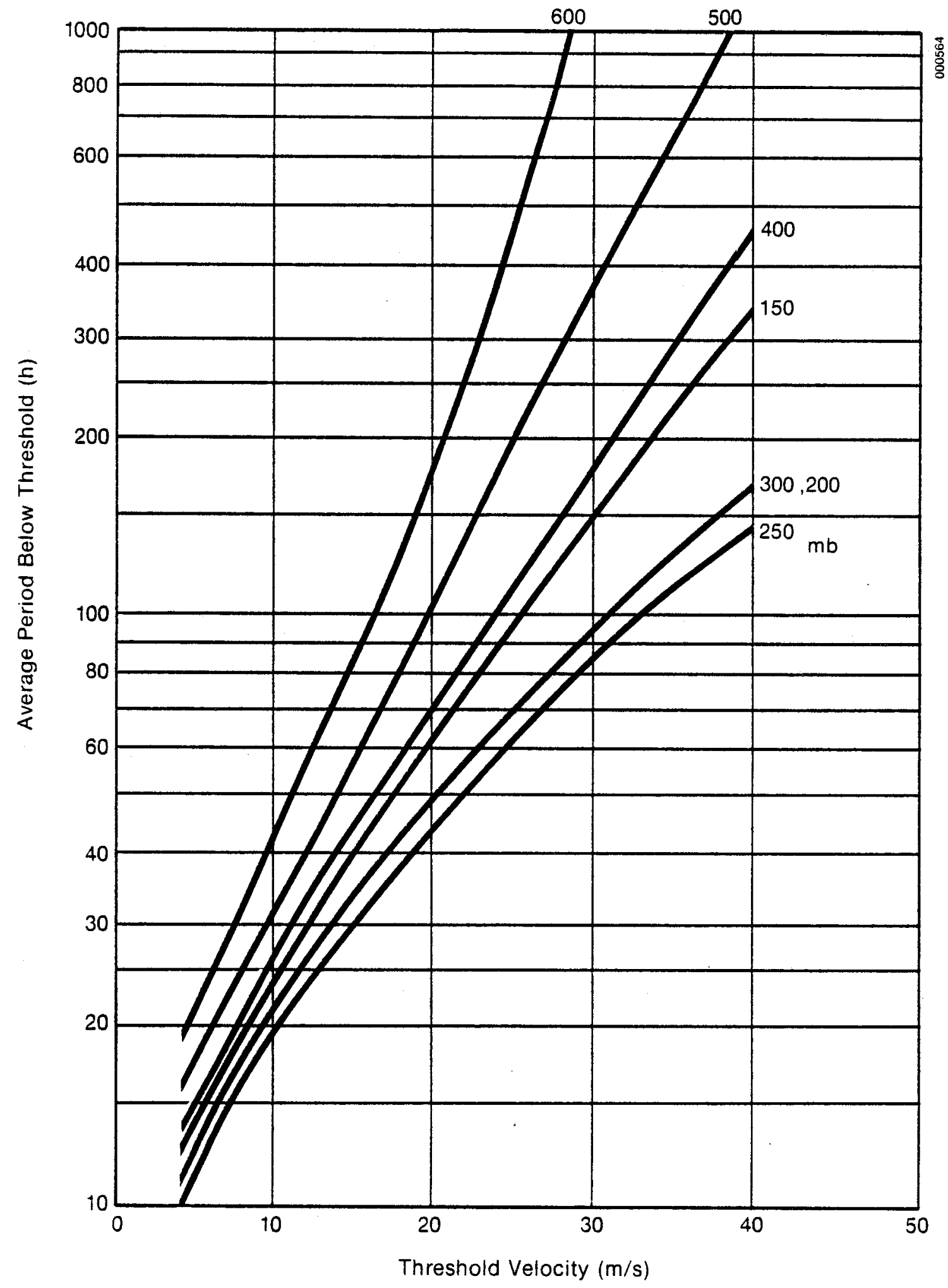

Figure C-2. Annual Calm-Period Analysis: Denver, CO 


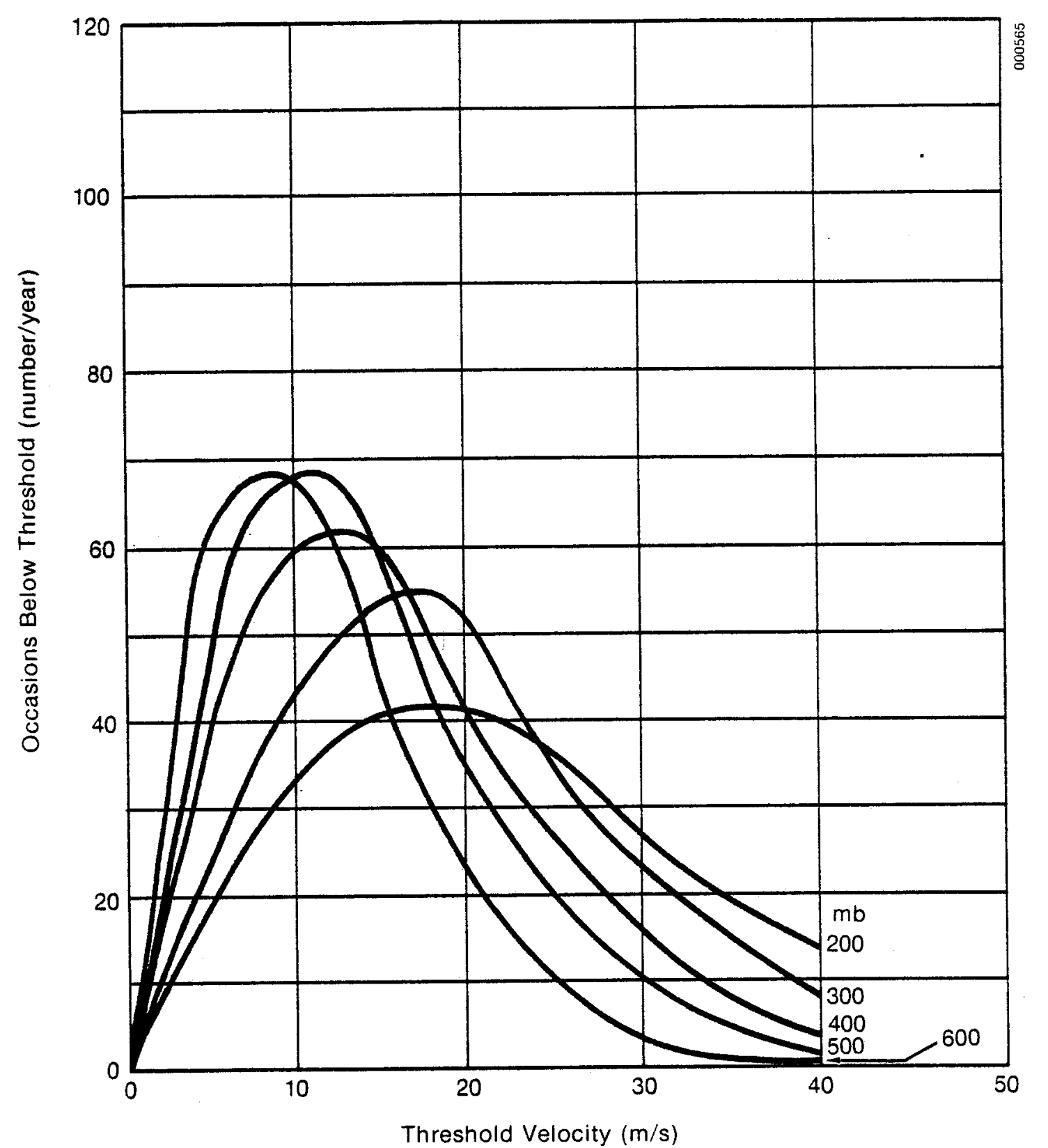

Figure C-3. Annual Calm-Period Analysis: Guadalupe Island, Mexico 


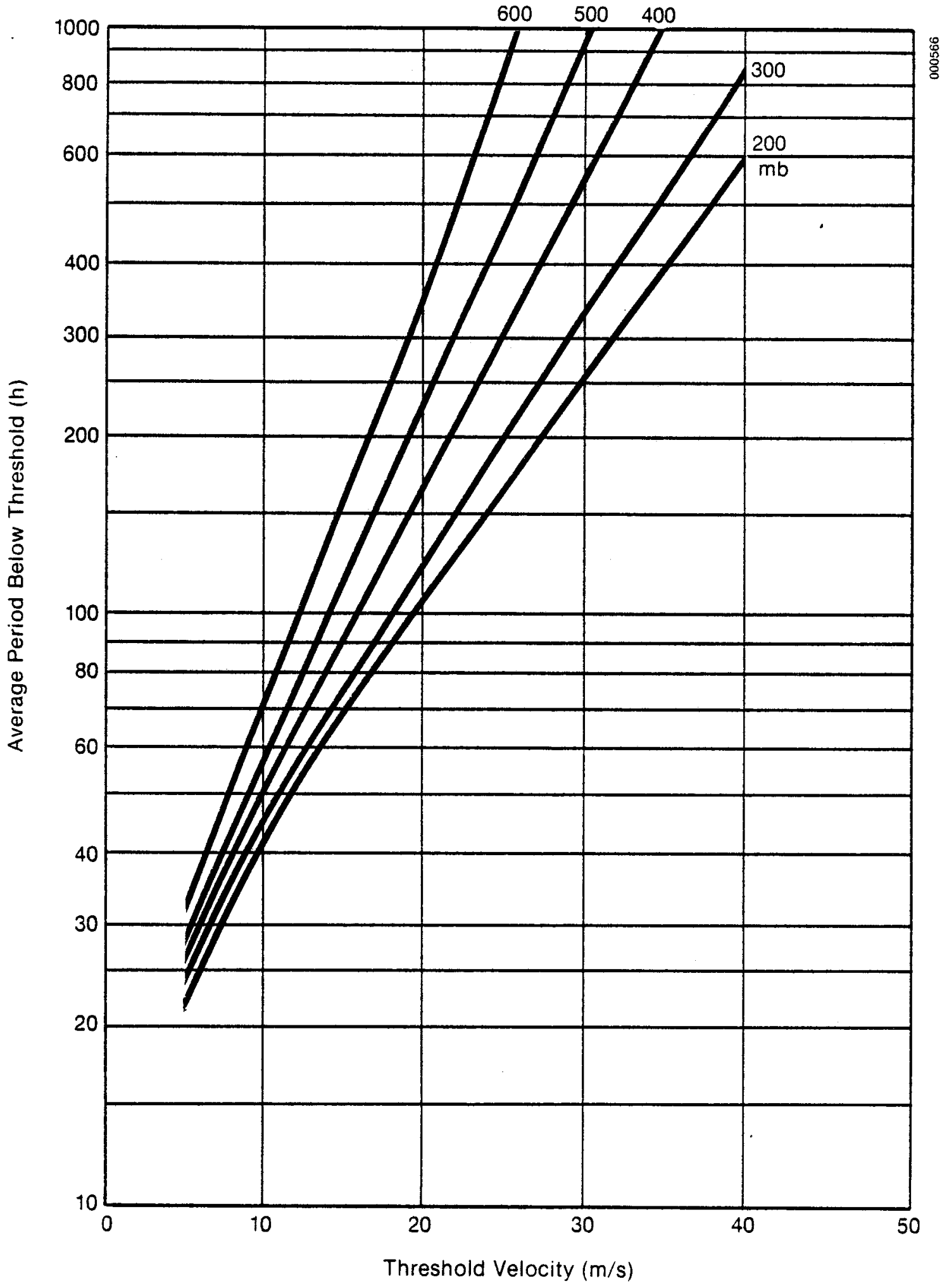

Figure C-4. Annual Calm-Period Analysis: Guadalupe Island, Mexico 


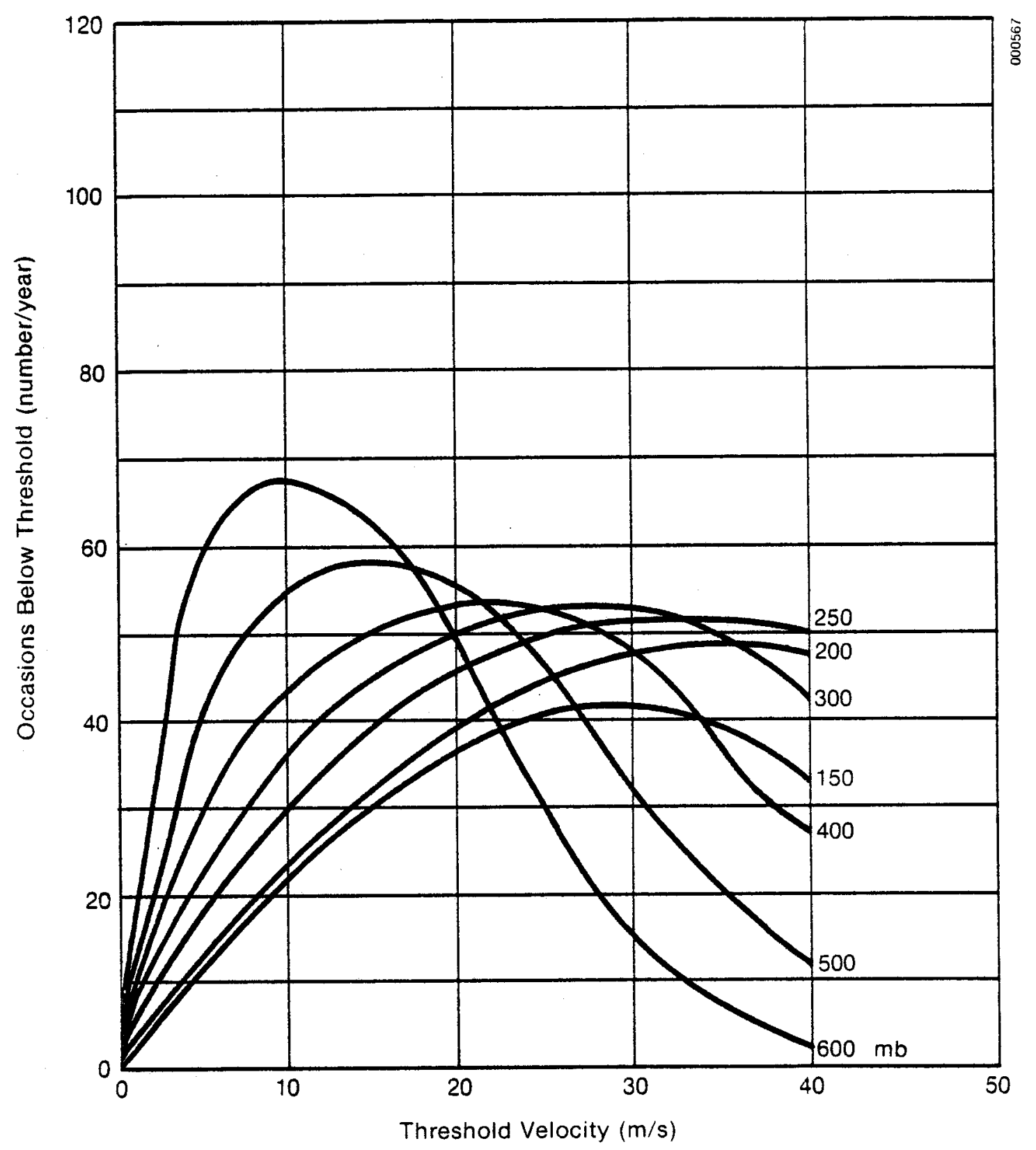

Figure C-5. Annual Calm-Period Analysis: Midland, TX 


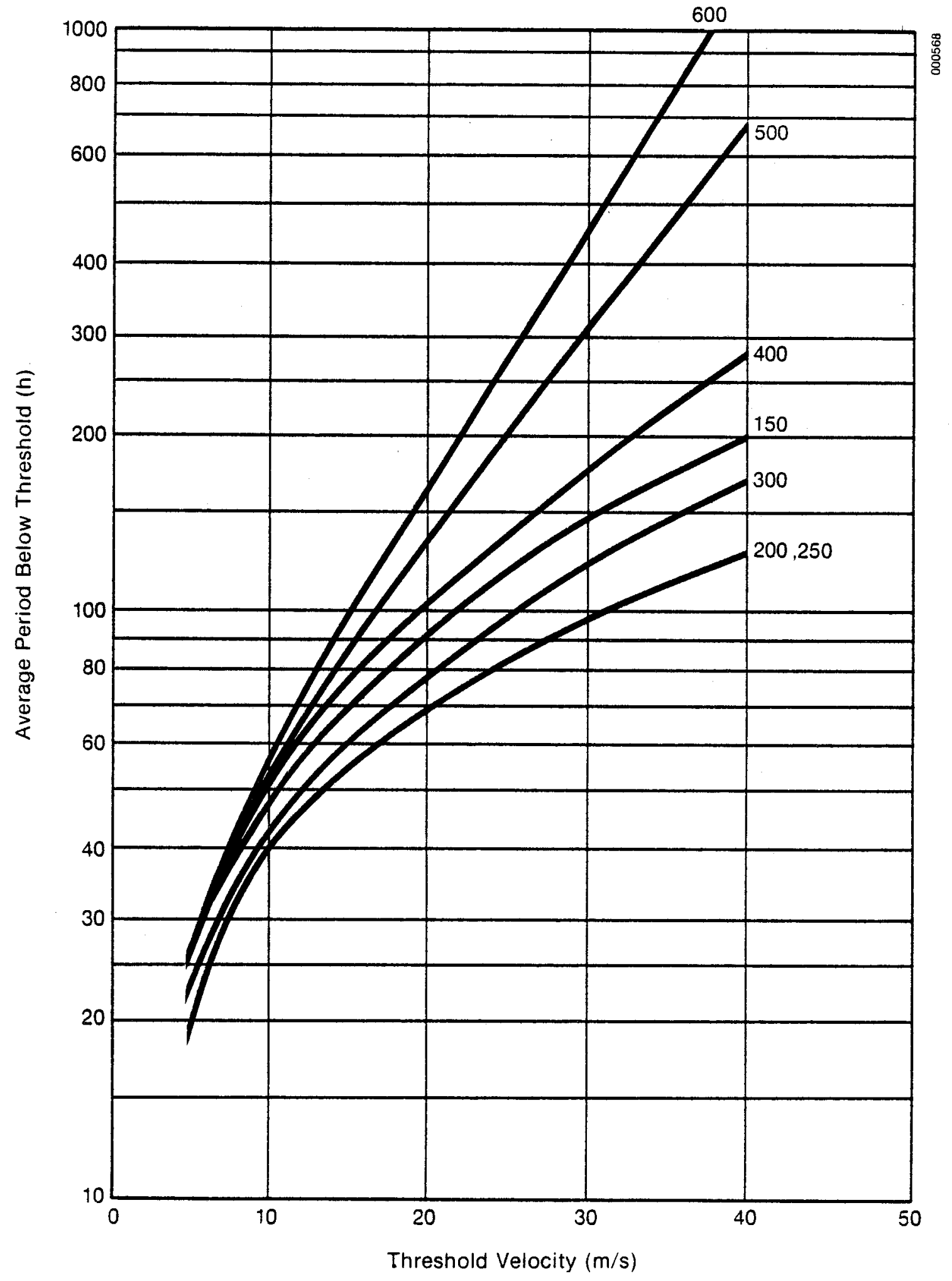

Figure C-6. Annual Calm-Period Analysis: Midland, TX 


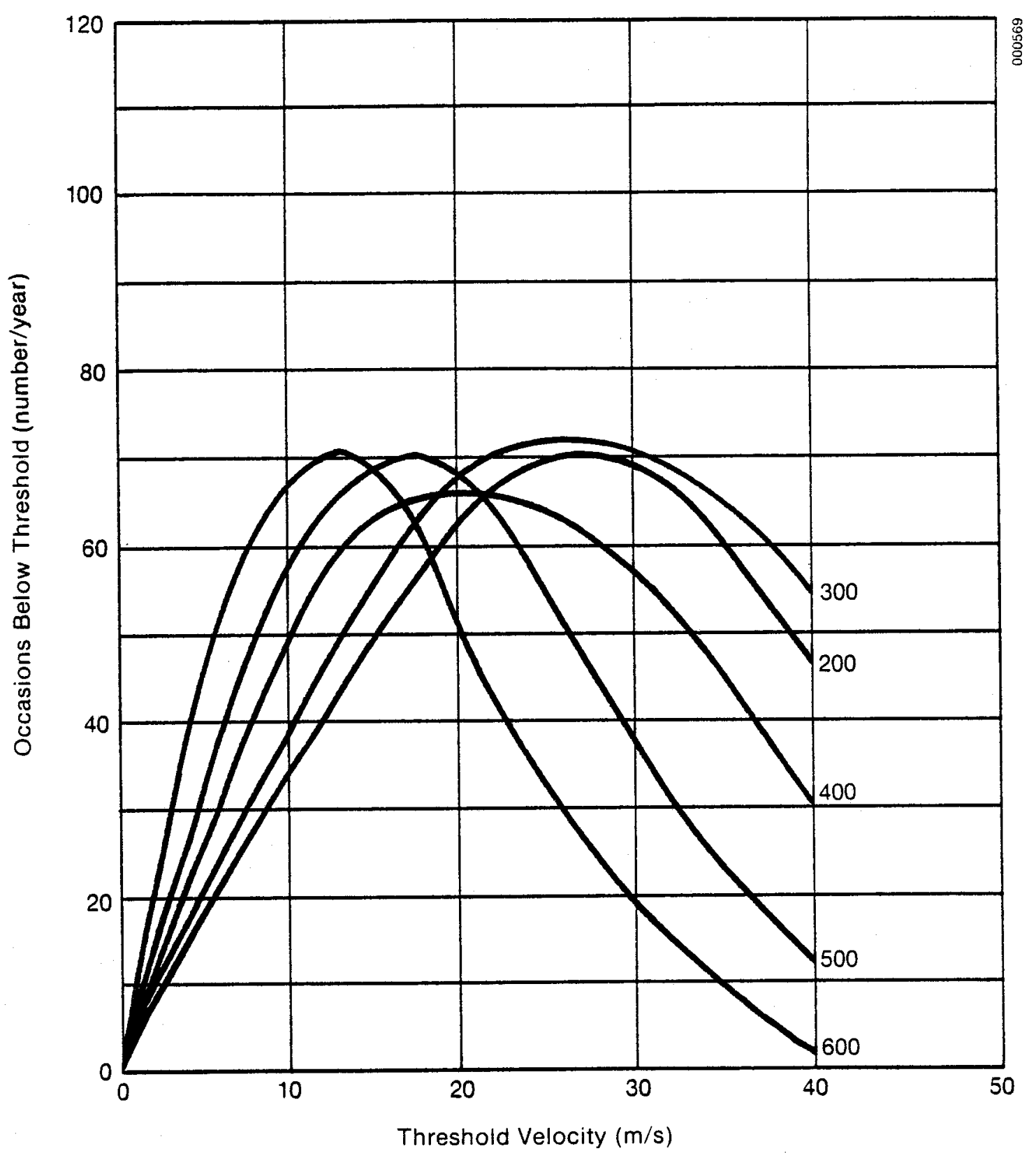

Figure C-7. Annual Calm-Period Analysis: Oakland, CA 


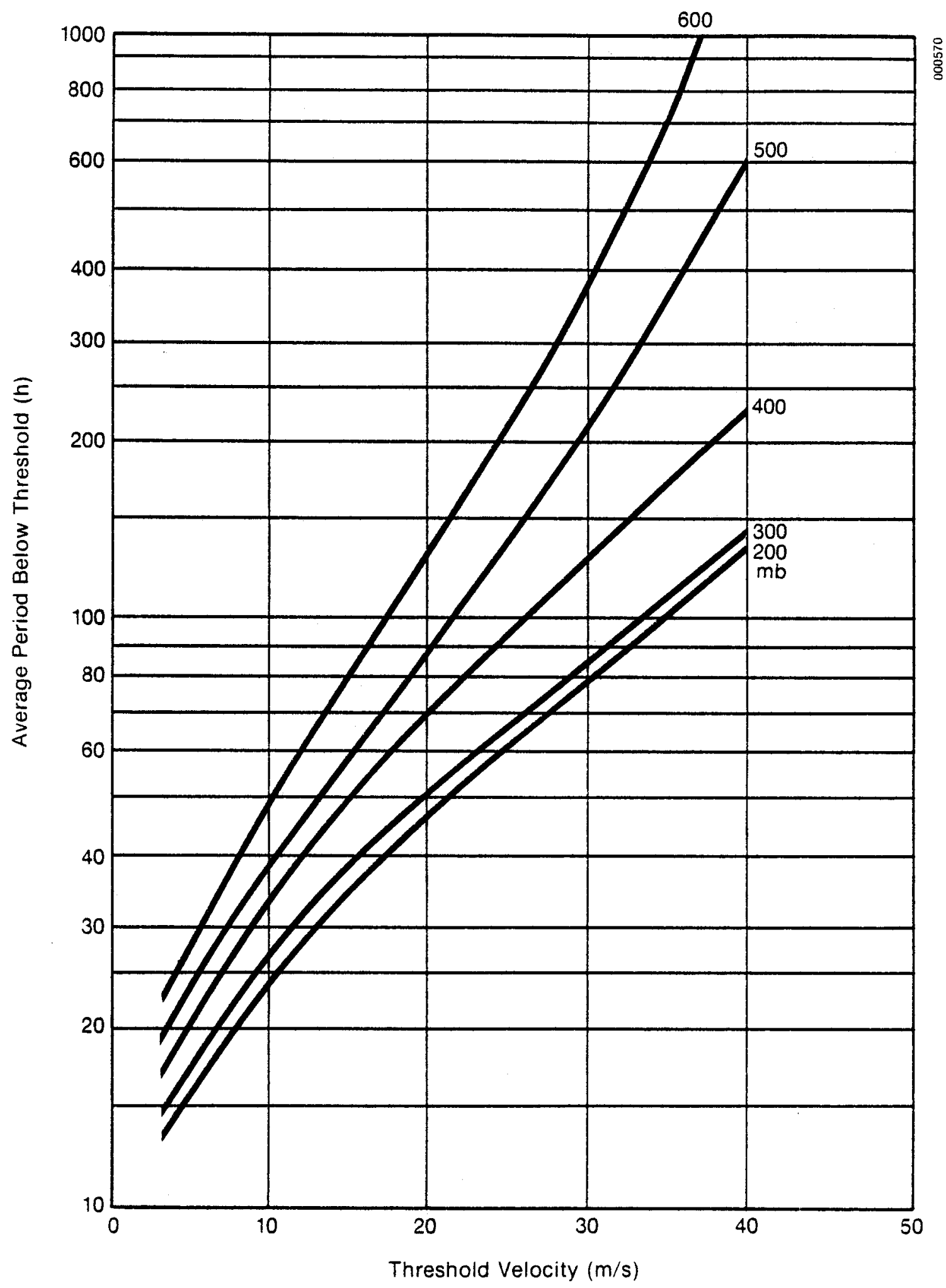

Figure C-8. Annual Calm-Period Analysis: Oakland, CA 


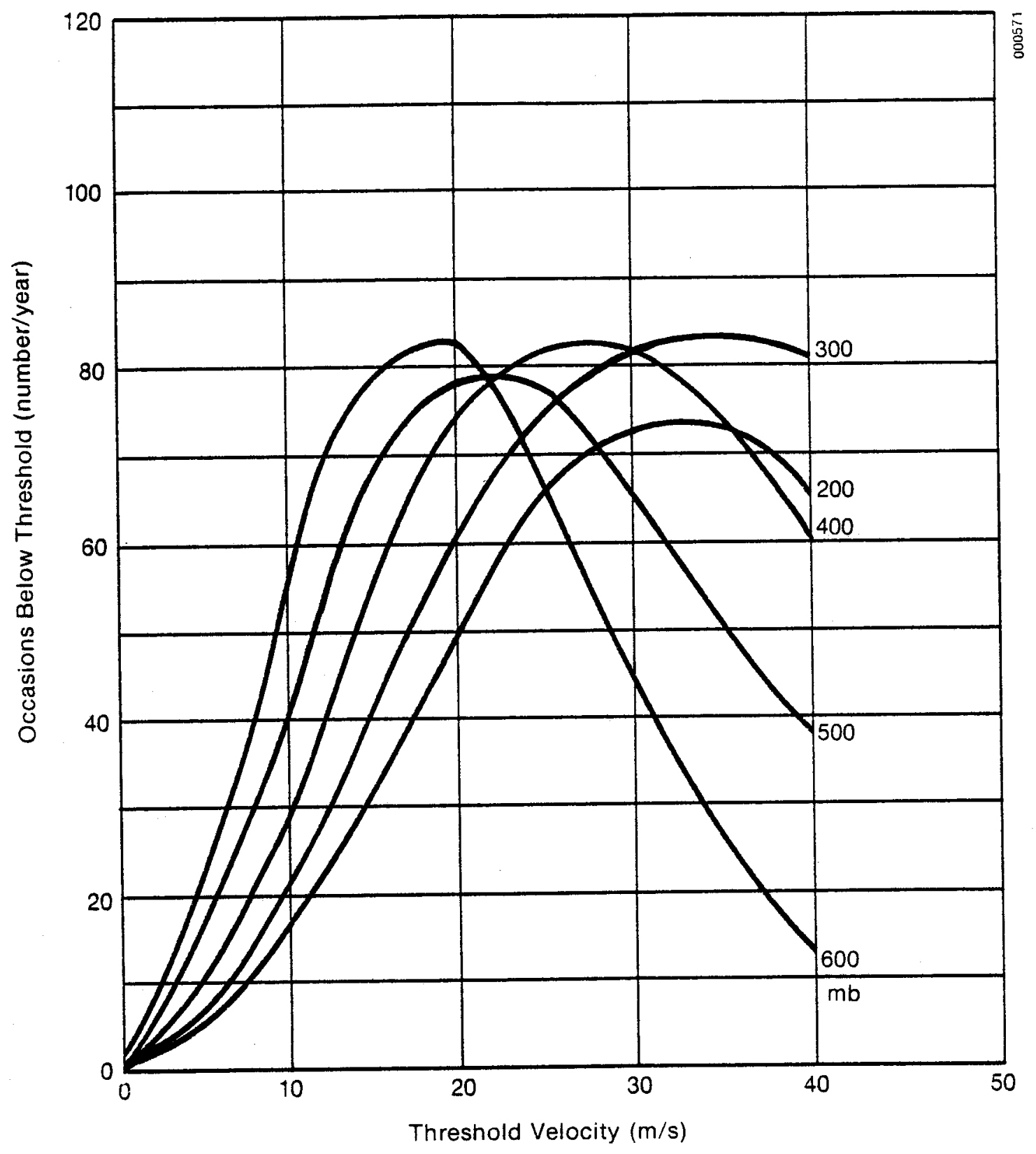

Figure C-9. Annual Calm-Period Analysis: Portland, ME 


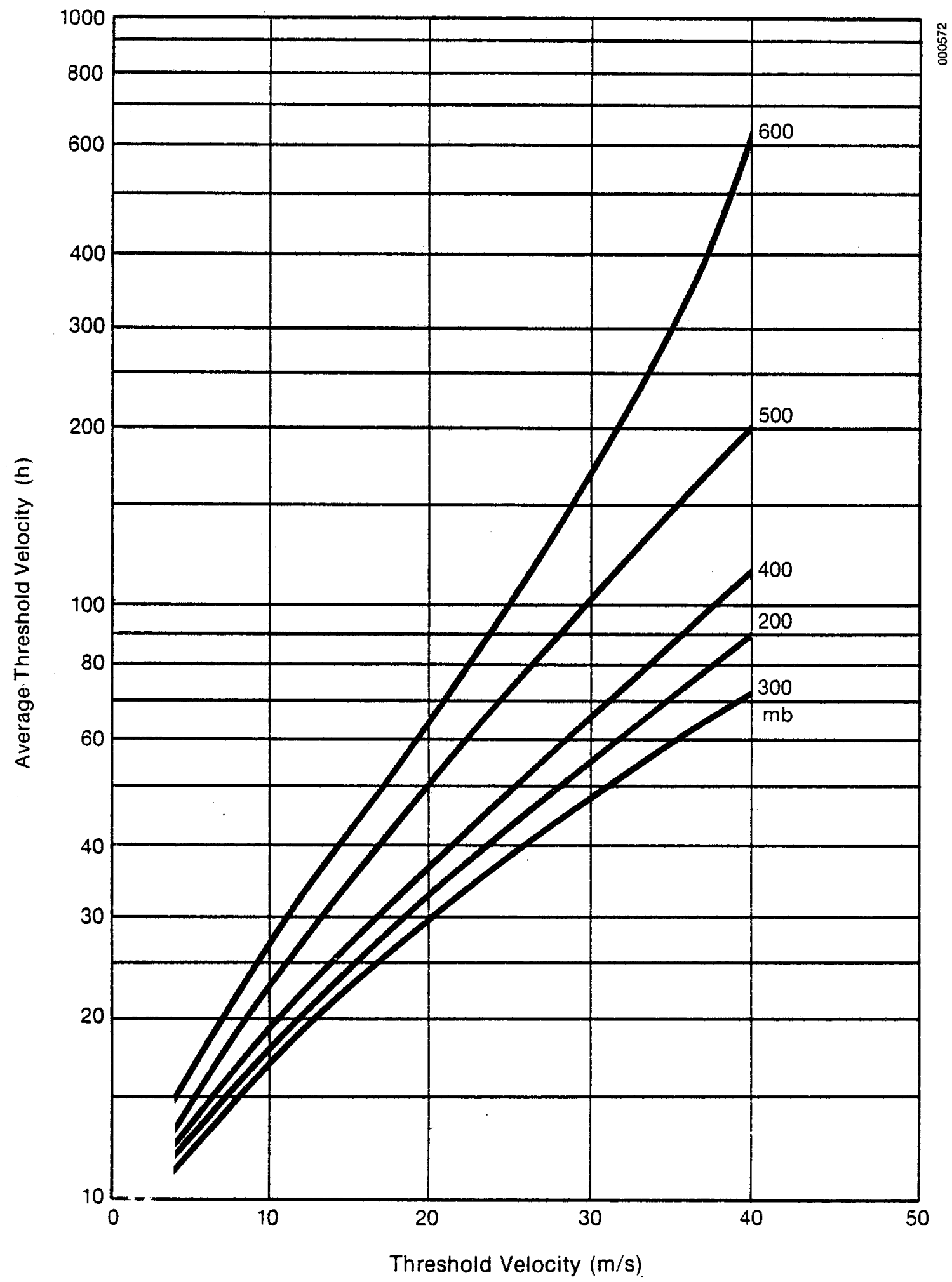

Figure C-10. Annual Calm-Period Analysis: Portland, ME 
APPENDIX D

USE OF THE ANNUAL PROBABILITY

DISTRIBUTION OF VELOCITY CHARTS 


\section{SEPI奉}




\section{APPENDIX D \\ USE OF THE ANNUAL PROBABILITY DISTRIBUTION OF VELOCITY CHARTS}

The Annual Probability Distribution of Velocity charts are given in Figs. B-1 through B-54 in App. B. In each of the charts the actual cumulative probabi1ities $P(V)$ are plotted against $V$ for various pressure levels between $700 \mathrm{mb}$ and $200 \mathrm{mb}$.

Furthermore the charts have been plotted on special paper known as Weibull paper [3]. On this paper the two-parameter Weibull distribution, given as

$$
P(V)=1-e^{-\left(V / V_{0}\right)^{\alpha}} V \geqslant 0,
$$

will appear as a straight-line plot. In this manner, a straight line may be drawn to. represent the actual distribution formed from the NCAR data.

The probability distribution given in Eq. 1 uses two parameters, $V_{0}$ and $\alpha$. In order to reduce this distribution to a straight-line plot on Weibull graph paper, one needs to compute the natural logarithm of both sides of Eq. 1 . Hence it follows that

$$
\sqrt{\ln [1 /[1-P(V)]}]=\left(V / V_{0}\right)^{\alpha / 2}
$$

If Eq. 2 is plotted on $\log -\log$ graph paper,

$$
\alpha / 2=\log (\sqrt{\ln \{1 /[1-\mathrm{P}(\mathrm{V})]\}}) / \log \left(\mathrm{V} / \mathrm{V}_{0}\right)
$$

In this way the slope of the straight-line plot of Fig. 2-7 is exactly $\alpha / 2$. In addition the value of $V_{0}$ is found from $V=V_{0}$ when $P(V)=(1-1 / e)$ $=0.633$.

Finally $\alpha$ is approximately 2 in our work, so that the slope of the straight line is approximately $45^{\circ}$ because $\alpha / 2 \simeq 1$.

Figure 2-7 of the text gives the Weibull probability distributions for Portland, Me., at altitudes of $700,500,400,300$, and $200 \mathrm{mb}$. The intersection of the appropriate Weibull straight line with the dotted horizontal line at $P(V)=63.3 \%$ gives the corresponding value of $V_{0}$, as read on the abscissa of the chart. The values of $V_{0}$ are tabulated in Table $D-1$ as read from Fig. 2-7 to an accuracy of $\pm 0.5 \mathrm{~m} / \mathrm{s}$.

To determine the value of $\alpha$, first choose the required straight-line distribution. Then draw another straight line parallel to this line so that it passes through the center of the target symbol near the top right corner of the figure. Next extend this parallel line to cross the vertical line at the extreme left side of the figure. This latter intersection gives the value of $\alpha$. The relevant values of $\alpha$ from $\mathrm{Fig}$. 2-7 are given in Table $D-1$ to a reading accuracy of about \pm 0.01 . 


\section{Table D-1. Values of $\nabla_{0}$ in \\ Portland, Maine}

\begin{tabular}{ccc}
\hline $\begin{array}{c}\text { Pressure } \\
(\mathrm{mb})\end{array}$ & $\begin{array}{c}\mathrm{V}_{\mathrm{p}} \\
(\mathrm{m} / \mathrm{s})\end{array}$ & $\alpha$ \\
\hline 700 & 16.5 & 1.98 \\
500 & 25.5 & 2.07 \\
400 & 31.5 & 2.07 \\
300 & 37.0 & 2.22 \\
200 & 35.5 & 2.21 \\
\hline
\end{tabular}

It is possible to show from the Weibull distribution given in Eq. 1 that the average annual wind speed $\bar{V}$ and the average annual power density $\bar{P}$ are the following functions of $v_{0}$ and $\alpha$ :

and

$$
\bar{V}=V_{0} \Gamma(1+1 / \alpha),
$$

$$
\overline{\mathrm{P}}=1 / 2 \rho \mathrm{v}_{0}^{3} \Gamma(1+3 / \alpha),
$$

where $\Gamma(x)$ is the gamma function that is widely tabulated.

Next, compare the mean velocities and power densities using Table D-1 with the actual computed values of $\bar{V}$ and $\bar{P}$ using the NCAR data. The comparison in Table D-2 verifies the validity or otherwise of our Weibull model. The first of the columns $\bar{V}$ and $\overrightarrow{\mathrm{P}}$ are for the Weibull model, while the second columns of $\bar{V}$ and $\bar{P}$ are formed from the NCAR data.

According to the results in Table D-2, the Weibull model gave good estimates of the mean wind speeds and the mean power densities.

We feel that the two-parameter Weibull model is generally satisfactory, which is in line with other wind energy results from workers such as Justus, Hennessey, and others. 
Table D-2. Weibu1l Model vs. Actual Data for Values of $\bar{V}$ and $\bar{P}$ in Portland, Maine

\begin{tabular}{|c|c|c|c|c|c|c|c|c|}
\hline \multirow[b]{2}{*}{$\begin{array}{l}\text { Pressure } \\
\quad(\mathrm{mb})\end{array}$} & \multirow[b]{2}{*}{$\Gamma(1+1 / \alpha)$} & \multirow[b]{2}{*}{$\Gamma(1+3 / \alpha)$} & \multirow[b]{2}{*}{$\begin{array}{c}\rho \\
\left(\mathrm{kg} / \mathrm{m}^{3}\right)\end{array}$} & \multirow[b]{2}{*}{$\begin{array}{c}1 / 2 \rho v_{o}^{3} \\
\left(k W / m^{2}\right)\end{array}$} & \multicolumn{2}{|c|}{ Weibul1 Mode1 } & \multicolumn{2}{|c|}{ Actual Data } \\
\hline & & & & & $\begin{array}{c}\bar{V} \\
(\mathrm{~m} / \mathrm{s})\end{array}$ & $\begin{array}{c}\overline{\mathrm{P}} \\
\left(\mathrm{kW} / \mathrm{m}^{2}\right)\end{array}$ & $\begin{array}{c}\bar{v} \\
(\mathrm{~m} / \mathrm{s})\end{array}$ & $\begin{array}{c}\overline{\mathbf{P}} \\
\left(\mathrm{kW} / \mathrm{m}^{2}\right)\end{array}$ \\
\hline 700 & 0.886 & 1.348 & 0.913 & 2.05 & 14.6 & 2.76 & 14.8 & 2.84 \\
\hline 500 & 0.886 & 1.285 & 0.695 & 5.76 & 22.6 & 7.40 & 22.5 & 7.53 \\
\hline 400 & 0.886 & 1.285 & 0.580 & 9.06 & 27.9 & 11.6 & 27.6 & 11.4 \\
\hline 300 & 0.886 & 1.203 & 0.460 & 11.65 & 32.8 & 14.0 & 32.8 & 14.1 \\
\hline 200 & 0.886 & 1.210 & 0.323 & 7.23 & 31.5 & 8.74 & 31.2 & 7.90 \\
\hline
\end{tabular}




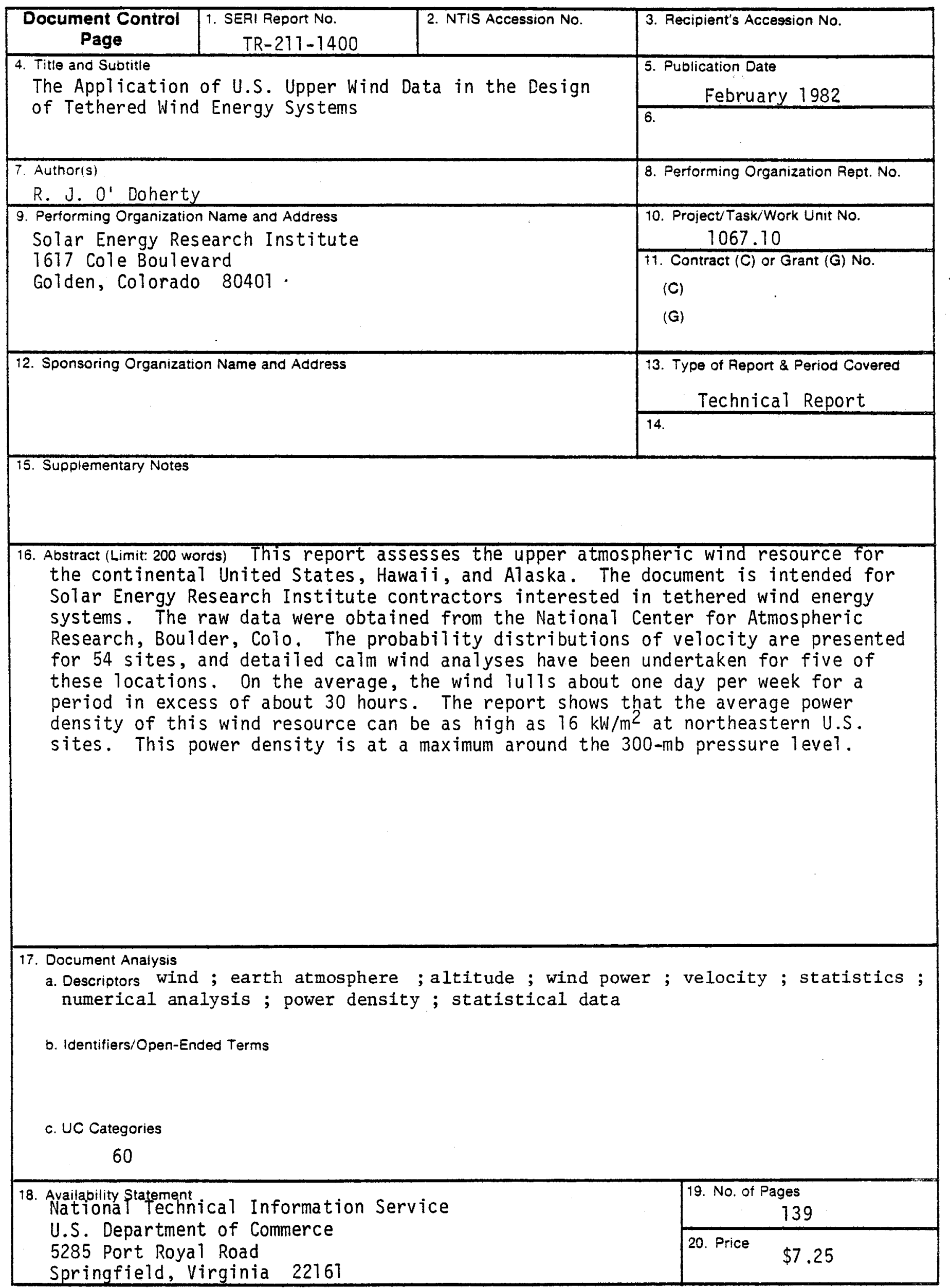

